\title{
NATO'S 1979 DUAL-TRACK DECISION: NATIONAL INTERESTS AND THE INFLUENCE OF FORMER POLITICAL LEADERS OF THE UNITED STATES OF AMERICA AND THE FEDERAL REPUBLIC OF GERMANY
}

\author{
A Monograph \\ by \\ LtCol Holger Draber \\ German Army
}

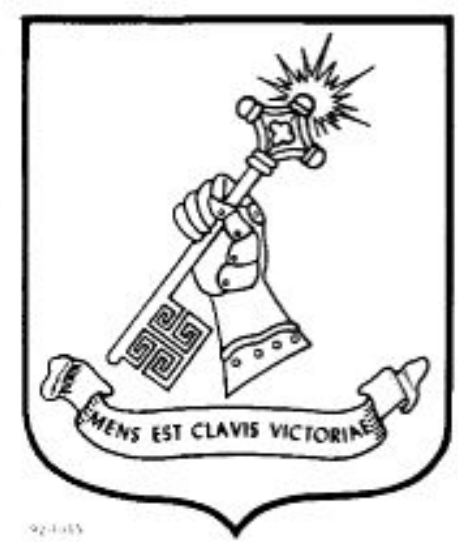

School of Advanced Military Studies United States Army Command and General Staff College

Fort Leavenworth, Kansas

AY 2013-2014

Approved for public release; distribution is unlimited. 
Public reporting burden for this collection of information is estimated to average 1 hour per response, including the time for reviewing instructions, searching existing data sources, gathering and

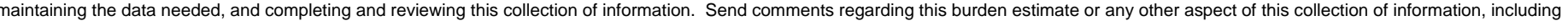


1204, Arlington, VA 22202-4302. Respondents should be aware that notwithstanding any other provision of law, no person shall be subject to any penalty for failing to comply with a collection of information if it does not display a currently valid OMB control number. PLEASE DO NOT RETURN YOUR FORM TO THE ABOVE ADDRESS

\begin{tabular}{l|l|l}
\hline 1. REPORT DATE $(D D-M M-Y Y Y Y)$ & 2. REPORT TYPE
\end{tabular}

\begin{tabular}{l|l}
$22-05-2014$ & Master's Thesis
\end{tabular}

4. TITLE AND SUBTITLE

NATO's 1979 Dual-track Decision:

National Interests and the Influence of Former Political

Leaders of the United States of America and

the Federal Republic of Germany

3. DATES COVERED (From - To) June 2013 - May 2014

5a. CONTRACT NUMBER

5b. GRANT NUMBER

5c. PROGRAM ELEMENT NUMBER

\section{AUTHOR(S)}

Draber, Holger 5d. PROJECT NUMBER

5e. TASK NUMBER

5f. WORK UNIT NUMBER

8. PERFORMING ORGANIZATION REPORT

School of Advanced Military Studies

250 Gibbon Avenue

Fort Leavenworth, Kansas 66027-2134

\begin{tabular}{|l|l}
\hline R. PERFORM & REPORT \\
\end{tabular}

\author{
9. SPONSORING / MONITORING AGENCY NAME(S) AND ADDRESS(ES) \\ Command and General Staff College \\ 731 Mcclellan Avenue
}

Fort Leavenworth, Kansas 66027-2134

11. SPONSOR/MONITOR'S REPORT
NUMBER(S)

\title{
12. DISTRIBUTION / AVAILABILITY STATEMENT
}

Approved for public release; distribution is unlimited.

\section{SUPPLEMENTARY NOTES}

\section{ABSTRACT}

On December 12, 1979, NATO formally decided on the modernization and deployment of intermediate-range theater nuclear weapons. These were to be stationed in Europe starting in 1983. At the same time, NATO offered to negotiate with the Soviet Union regarding arms control for intermediate-range nuclear weapons. This decision is commonly known as NATO's dual-track decision. The United States of America and the Federal Republic of Germany contributed fundamentally to the agreement. This monograph examines how the respective U.S. and German history, national security interests and strategies shaped NATO's 1979 dualtrack decision. Particular emphasis is given to how the principal political leaders of both countries-in retrospect-described and assessed the origins of the dual-track decision. This includes their personal roles, personal interpretations and the influence of their personal relationships to each other on the decision making.

\section{SUBJECT TERMS}

NATO History, Foreign Affairs, National Security, Strategy, Policymaking, Strategic Leadership, Jimmy Carter, Zbigniew Brzezinski, Helmut Schmidt, Hans Dietrich Genscher, NATO Strategy

\begin{tabular}{|c|c|c|c|c|c|}
\hline \multicolumn{3}{|c|}{ 16. SECURITY CLASSIFICATION OF: } & \multirow{2}{*}{$\begin{array}{l}\text { 17. LIMITATION } \\
\text { OF ABSTRACT } \\
\text { UU }\end{array}$} & \multirow{2}{*}{$\begin{array}{l}18 . \\
\text { NUMBER } \\
105\end{array}$} & \multirow{2}{*}{$\begin{array}{l}\text { 19a. NAME OF RESPONSIBLE } \\
\text { PERSON } \\
\text { 19b. TELEPHONE NUMBER } \\
\text { (include area code) }\end{array}$} \\
\hline $\begin{array}{l}\text { a. REPORT } \\
\text { Unclassified }\end{array}$ & $\begin{array}{l}\text { b. ABSTRACT } \\
\text { Unclassified }\end{array}$ & $\begin{array}{l}\text { c. THIS PAGE } \\
\text { Unclassified }\end{array}$ & & & \\
\hline
\end{tabular}




\section{MONOGRAPH APPROVAL PAGE}

Name of Candidate: LtCol Holger Draber

Monograph Title: $\quad$ NATO’s 1979 Dual-track Decision: National Interests and the Influence of Former Political Leaders of the United States of America and the Federal

Approved by: Republic of Germany

Robert T. Davis II, Ph.D.

, Monograph Director

G. Scott Gorman, Ph.D.

, Deputy Director Academics, SAMS

, Director, School of Advanced Military Studies

Henry A. Arnold III, COL, IN

Accepted this 22nd day of May 2014 by:

, Director, Graduate Degree Programs

Robert F. Baumann, Ph.D.

The opinions and conclusions expressed herein are those of the student author and do not necessarily represent the views of the U.S. Army Command and General Staff College or any other government agency. (References to this study should include the foregoing statement.) 


\begin{abstract}
NATO'S 1979 DUAL-TRACK DECISION: NATIONAL INTERESTS AND THE INFLUENCE OF FORMER POLITICAL LEADERS OF THE UNITED STATES OF AMERICA AND THE FEDERAL REPUBLIC OF GERMANY, by LtCol Holger Draber, German Army, 105 pages.

On December 12, 1979, NATO formally decided on the modernization and deployment of intermediate-range theater nuclear weapons. These were to be stationed in Europe starting in 1983. At the same time, NATO offered to negotiate with the Soviet Union regarding arms control for intermediate-range nuclear weapons. This decision is commonly known as NATO's dualtrack decision. The United States of America and the Federal Republic of Germany contributed fundamentally to the agreement. This monograph examines how the respective U.S. and German history, national security interests and strategies shaped NATO’s 1979 dual-track decision. Particular emphasis is given to how the principal political leaders of both countries-in retrospect - described and assessed the origins of the dual-track decision. This includes their personal roles, personal interpretations and the influence of their personal relationships to each other on the decision making.
\end{abstract}




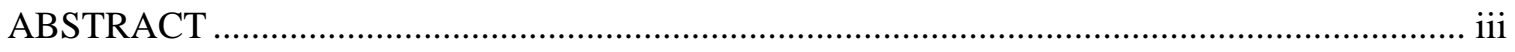



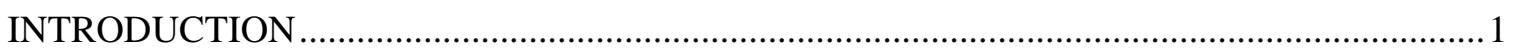

FLEXIBLE RESPONSE, DÉTENTE, AND TACTICAL NUCLEAR WEAPONS .......................8

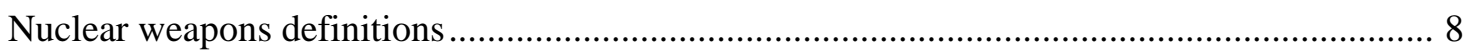

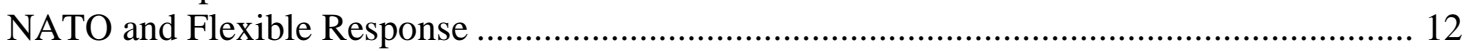

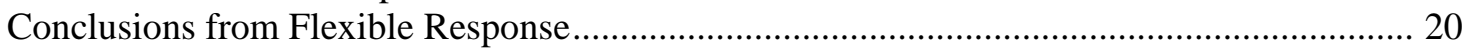

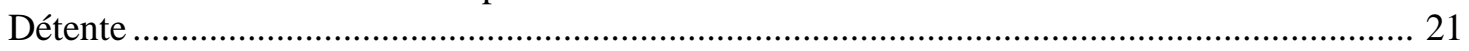



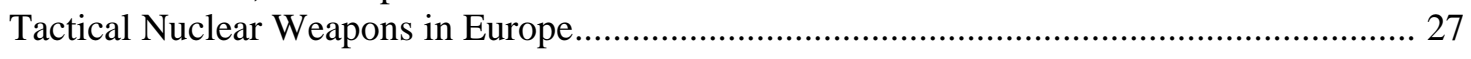

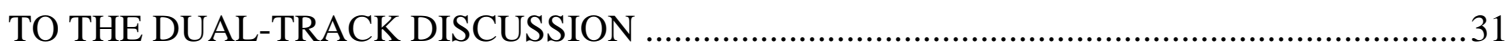

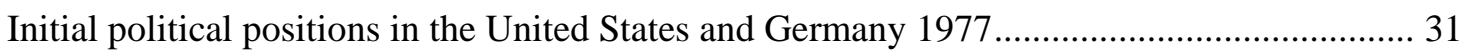



The 1977 speech at the International Institute of Strategic Studies (IISS) ............................... 40

Consequences of the speech and implementation of NATO's High Level Group (HLG)....... 44

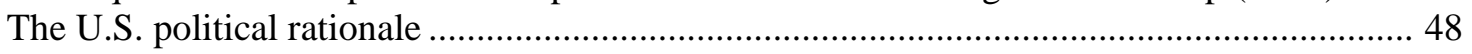





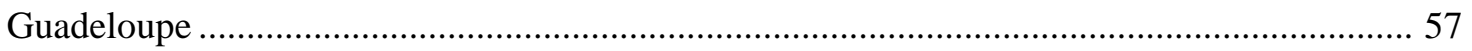



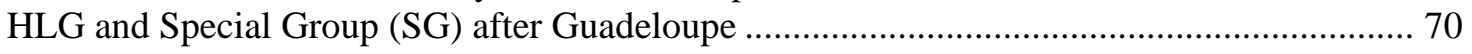

NATO political discussions prior to the dual-track decision ............................................... 73

THE DUAL-TRACK DISCUSSION, ASSESSMENTS, AND CONSEQUENCES ...................76

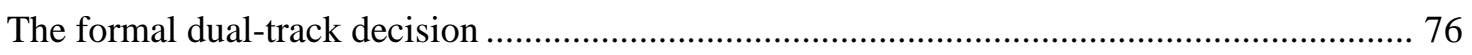

Assessment of the dual-track decision in the memoirs of former political leaders................... 79

Assessment of the dual-track decision by contemporary scholars ......................................... 84



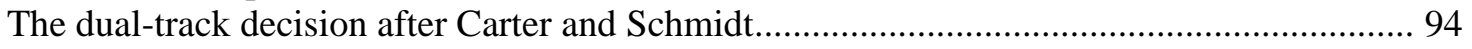



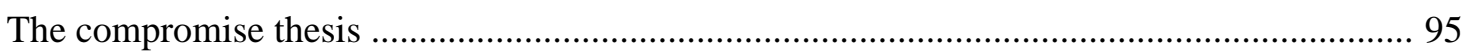








\section{ACRONYMS}

\begin{tabular}{|c|c|}
\hline $\mathrm{ABM}$ & Antiballistic Missile \\
\hline $\mathrm{ADM}$ & Atomic Demolition Munition \\
\hline ALCM & Air-Launched Cruise Missile \\
\hline CDU & Christian Democratic Union (Germany) \\
\hline CSCE & Conference on Security and Cooperation in Europe \\
\hline CSU & Christian Social Union (Germany) \\
\hline DCA & Dual Capable Aircraft \\
\hline ERW & Enhanced Radiation Weapon \\
\hline FDP & Free Democratic Party (Germany) \\
\hline GDR & German Democratic Republic \\
\hline GLCM & Ground-Launched Cruise Missile \\
\hline HLG & High Level Group (NATO) \\
\hline ICBM & Intercontinental Ballistic Missile \\
\hline INF & Intermediate Range Nuclear Forces \\
\hline LRTNF & Long-Range Theater Nuclear Forces \\
\hline LRTNW & Long-Range Theater Nuclear Weapon \\
\hline LTDP & Long-Term Defence Programme (NATO) \\
\hline MAD & Mutual Assured Destruction \\
\hline MBFR & Mutual and Balanced Force Reductions \\
\hline MC & Military Committee (NATO) \\
\hline NAC & North Atlantic Council (NATO) \\
\hline NATO & North Atlantic Treaty Organization \\
\hline NDAC & Nuclear Defence Affairs Committee (NATO) \\
\hline NPG & Nuclear Planning Group (NATO) \\
\hline NSC & National Security Council (USA) \\
\hline NSNW & Non-Strategic Nuclear Weapon \\
\hline
\end{tabular}




$\begin{array}{ll}\text { SALT } & \text { Strategic Arms Limitation Talks } \\ \text { SCG } & \text { Special Consultation Group (NATO) } \\ \text { SG } & \text { Special Group (NATO) } \\ \text { SLCM } & \text { Sea-Launched Cruise Missile } \\ \text { SNW } & \text { Strategic Nuclear Weapon } \\ \text { SPD } & \text { Social Democratic Party (Germany) } \\ \text { TNF } & \text { Theater Nuclear Forces } \\ \text { TNW } & \text { Tactical Nuclear Weapon }\end{array}$




\section{INTRODUCTION}

On December 12, 1979, NATO formally decided on the modernization and deployment of intermediate-range theater nuclear weapons. These were to be stationed in Europe starting in 1983. At the same time, NATO offered to negotiate with the Soviet Union regarding arms control for intermediate-range nuclear weapons. This decision is commonly known as NATO's dualtrack decision. The United States of America and the Federal Republic of Germany contributed fundamentally to the agreement. ${ }^{1}$ The dual-track decision led to controversial and emotional discussions in the Federal Republic of Germany until the late 1980s about nuclear weapons. This was the second time in West Germany’s history that nuclear weapons polarized politics and the entire German society. In 1957-58, the discussion about a possible nuclear armament of the Bundeswehr caused similar effects as the debate about NATO’s theater nuclear weapons modernization in 1979.

The dual-track decision can only be understood by taking NATO’s political and military framework into account. This framework was established in the 1960s and remained in place until the end of the Cold War. The Harmel Report of 1967 stressed the two pillars of military security and political détente. NATO’s Flexible Response strategic concept described the military use of the alliance's deterrence capabilities. Prior to the dual-track decision, the United States and the Soviet Union conducted negotiations to limit the amount of strategic nuclear weapons - the

${ }^{1}$ In this monograph, the expression Germany is used when referring to the Federal Republic of Germany. The German Democratic Republic (GDR) is mentioned by her full name. This is in line with the historical denotation in both former German states. The German Democratic Republic generally used the abbreviation GDR — or in German: DDR respectively—as her official name. The Federal Republic of Germany never used the abbreviated form FRG in official writing. The German Democratic Republic was not acknowledged by the Federal Republic of Germany as a sovereign state according to international law. This was expressed in the so-called Hallstein-doctrine. For a more thorough description see Bundesarchiv der Bundesrepublik Deutschland, “1955: Die Hallstein-Doktrin,” Das Bundesarchiv, http://www.bundesarchiv.de/oeffentlichkeitsarbeit/bilder_dokumente/01366/index.html.de (accessed January 21, 2014). 
Strategic Arms Limitation Talks (SALT). It was generally believed that balanced strategic equilibrium on both sides would prevent the possibility of either side to attacking the other.

While these negotiating continued, the Soviet Union continued fielding new SS-20 missiles with a maximum range exceeding $5,000 \mathrm{~km} .{ }^{2}$ These intermediate-range missiles that could not reach the United States were not part of the SALT agenda. Nevertheless, many of these weapons targeted European soil. From a European point of view, these weapons were part of a so called grey zone and considered to be euro-strategic. ${ }^{3}$ In a speech at the International Institute of Strategic Studies (IISS) in London on October 28, 1977, German Federal Chancellor Helmut Schmidt stressed amongst other things the requirement for overall balanced military capabilities within Europe. Two years later and after intensive and controversial discussions, NATO responded to this request with the dual-track decision.

This monograph examines how the respective U.S. and German history, national security interests and strategies shaped NATO’s 1979 dual-track decision. Particular emphasis is given to how the principal political leaders of both countries — in retrospect—described and assessed the origins of the dual-track decision. This includes their personal roles, personal interpretations and the influence of their personal relationships to each other on the decision making.

Thirty-four years after the formal dual-track decision, primary and secondary sources including official documents, speeches, academic assessments and papers as well as contemporary literature are widely available. These include studies about NATO at that time, the Flexible Response strategic concept, the conduct of arms limitation talks and treaties, the historical situation of the United States and Germany, and a selection of biographies about key

\footnotetext{
${ }^{2}$ For the SALT negotiations, weapons with a maximum range of more than $5500 \mathrm{~km}$ were considered to be strategic nuclear weapons. Compare with Ivo H. Daalder, The Nature and Practice of Flexible Response: NATO Strategy and Theater Nuclear Forces Since 1967 (New York: Columbia University Press, 1991), 159.

${ }^{3}$ In the literature, the expressions grey zone or gray zone, and euro-strategic or eurostrategic are in use.
} 
leaders. A selection of these sources is used to describe the general setting prior to the dual track decision.

Due to the scope of this monograph, the analysis is limited, focusing on the period of President James Earl Carter’s presidency from January 20, 1977 to January 20, 1981. Also, the monograph's focus lies with the security relationship of the United States of America and the Federal Republic of Germany and their respective NATO commitments. Bilateral relations with other countries as well as economic, social, and financial questions are not analyzed in depth. ${ }^{4}$ Due to the specific individual power relations within the United States of America and Germany at the time under consideration, the author focuses on key leader's personal memoirs that are relevant to the dual-track decision.

The memoirs of the President of the United States, his National Security Adviser, the Chancellor of the Federal Republic of Germany, and the German Foreign Minister of that time are used. The personal memoirs of James Earl (Jimmy) Carter, Zbigniew Brzezinski, Helmut Schmidt, and Hans-Dietrich Genscher provide the inputs to compare academic findings and assessments with their individual retrospective views and assessments about events and decisions in the context of the dual track decision. ${ }^{5}$ Quotes of and content from these memoirs are used to support academic findings or to demonstrate different perceptions or interpretations as well as the respective rationales behind decisions and actions. The influence of personal relations between

\footnotetext{
${ }^{4}$ A more comprehensive description about the positions of other NATO members can be found in Ivo H. Daalder, The Nature and Practice of Flexible Response. For economic, financial, and social questions compare with Helga Haftendorn, Sicherheit und Stabilität: Außenbeziehungen des Bundesrepublik zwischen Ölkrise und NATO-Doppelbeschlu $\beta$ (München: Deutscher Taschenbuch Verlag, 1986). Also see Klaus Wiegrefe, Das Zerwürfnis: Helmut Schmidt, Jimmy Carter und die Krise der deutsch-amerikanischen Beziehungen (Berlin: Propyläen, 2005).

${ }^{5}$ Jimmy Carter, Keeping Faith: Memoirs of a President (New York: Bantam Books, 1982), Zbigniew Brzezinski, Power and Principle: Memoirs of the National Security Adviser 1977-1981 (New York: Farrar, Straus, Giroux, 1983), Hans-Dietrich Genscher, Erinnerungen (Berlin: Siedler Verlag, 1995), and Helmut Schmidt, Menschen und Mächte (Berlin: Siedler Verlag, Jubiläumsausgabe, 1999). It should be noted that Helmut Schmidt's book are not classical memoirs. His book covers his personal experiences with the Soviet Union, the United States and China until 1987.
} 
these leaders on decisions is analyzed based on their individual descriptions and compared with statements and findings in other works. Biographies about these former political leaders are used to analyze the characteristics and backgrounds of the respective individuals. ${ }^{6}$ These biographies complement the memoirs on contexts, motives, differences, and analogies of the respective personalities. ${ }^{7}$ Inputs from memoirs and biographies must always be assessed against the background of additional works. In this monograph, the works of several scholars and journalists served this purpose.

Peter Bourne characterized Jimmy Carter as an optimistic Georgian politician with high moral standards and values based on his strong Christian belief. ${ }^{8}$ Carter worked his way up in his hometown of Plains, Georgia and eventually became Georgia’s Governor. He was never a member of a U.S administration or Congress prior to his election as President of the United States. Carter had limited practical foreign politics experience. He was described as a very smart, determined individual with a winning, rather calm personality. His actions were characterized by full engagement without sparing himself on any issue he considered to be of importance. Also, he

\footnotetext{
${ }^{6}$ Concerning Jimmy Carter, the findings about his roots and characteristics are taken from Peter G. Bourne, Jimmy Carter: A Comprehensive Biography from Plains to Postpresidency (New York: Scribner, 1997). Details about Zbigniew Brzezinski are taken from Charles Gati, ed., Zbig: The Strategy and Statecraft of Zbigniew Brzezinski (Baltimore: The Johns Hopkins University Press, 2013). The main biographies about Helmut Schmidt used for this monograph are Hartmut Soell, Helmut Schmidt: 19181969, Vernunft und Leidenschaft (München: Deutsche Verlags-Anstalt, 2003) and Hartmut Soell, Helmut Schmidt: 1969 bis heute, Macht und Verantwortung (München: Deutsche Verlags-Anstalt, 2008). Findings about Hans-Dietrich Genscher are entirely based on his comprehensive personal memoirs.

${ }^{7}$ It is important to recognize that memoirs and biographies reflect the personal thoughts of the respective authors. Memoirs are subjective, though some authors try to be as objective as possible. HansDietrich Genscher's memoirs are a good example for this-at least for the period of time under consideration. He generally refrained from criticizing the characters and personalities of the other three individuals under consideration in this monograph. Biographies can be both subjective and objective, depending on the relationship of the author to his subject. Both biographers of Jimmy Carter and Helmut Schmidt clearly have positive attitudes towards their subjects. Still, both do not avoid mentioning negative aspects or perceptions.
}

${ }^{8}$ Peter G. Bourne, Jimmy Carter: A Comprehensive Biography from Plains to Postpresidency. Peter Bourne supported Jimmy Carter since the end of the 1960s and eventually became a member of his administration. He provides a very thorough description of Carter's career as well as his personal background. 
was able to use unorthodox methods and approaches. He served in the U.S. Navy mainly as a submariner but never had real combat experience. Carter had a scientific and agricultural background and was involved in nuclear powered submarine development while serving in the Navy.

Hartmut Soell characterized Helmut Schmidt as a very strong personality, with distinct moral standards and a tendency to instruct other people. ${ }^{9}$ Helmut Schmidt was a lieutenant in the German Wehrmacht and participated in the Russian campaign. After the war, he witnessed the devastation the conflict had caused all over Europe. This led to his general conviction that war in Europe must never occur again and also that the Soviet's leadership did not have an interest in starting another war. He considered a strong western Social Democracy to be the greatest challenge to Soviet communism. His self-consciousness and expertise in combination with his nature to respond to other peoples arguments in a very direct, at times rather emotional way, led to different perceptions about his personality throughout his entire political career. On one hand, he was considered to be a brilliant expert on defense, financial, and economic questions and highly appreciated within Germany as well as the international community. On the other hand, contemporaries reproached Schmidt as being characterized by a certain degree of arrogance and impatience. Early in his career, he was nicknamed "Schmidt the lip” because of his rather blunt statements in the German Bundestag as well as in public.

Schmidt was by trade an economist and became a defense expert within the Social Democratic Party (SPD). As Senator for Internal Affairs in Hamburg he was specifically known for his leadership and crisis management skills in the aftermath of the 1962 flood catastrophe.

${ }^{9}$ Concerning Helmut Schmidt, the main findings are taken from Hartmut Soell’s biography. Soell is a history professor and worked for Schmidt at the time when Schmidt led the SPD Bundestag faction. Later, Soell was an SPD member of the Bundestag from 1980-1984. See Hartmut Soell, Helmut Schmidt: 1918-1969, Vernunft und Leidenschaft, and Hartmut Soell, Helmut Schmidt: 1969 bis heute, Macht und Verantwortung. 
Schmidt was SPD faction leader of the German Bundestag and Minister for Economy, Finances and Defense prior to his election as Federal Chancellor. Still, he was not undisputed in his own party and only became Chancellor after Willy Brandt had to resign after the Guillaume affair in April $1974 .{ }^{10}$ Schmidt led Germany through the aftermath of the 1973 oil crisis. At the end of the 1970s, Germany’s economy was in a better condition than many other Western states.

Due the great amount of contemporary literature and the specific focus of this monograph on Germany and the United States, a mix of secondary sources are used, reflecting scholarly opinions from both countries. The second section of this monograph provides an understanding of the historical framework. It describes the origins of NATO’s Flexible Response strategic concept. Additionally, the initial political situation with respect to Germany and the United States is portrayed. This section also gives a general overview about nuclear weapons including definitions. Findings are presented mainly based on the works of the authors Jane E. Stromseth and Francis J. Gavin. ${ }^{11}$ The third section of this monograph focuses on developments towards the dual-track decision. Findings from a contemporary point of view are based to a great degree on the works of German scholar Helga Haftendorn, the former U.S. Ambassador to NATO Ivo Daalder, and the German journalist Klaus Wiegrefe. ${ }^{12}$ These works are supplemented by more

\footnotetext{
${ }^{10}$ Günter Guillaume was a close aide to Chancellor Willy Brandt and finally revealed to be an East German spy. As a result of this discovery, Willy Brandt resigned as German Chancellor but kept his position as chairman of the SPD. For a more detailed description see Soell, Helmut Schmidt: 1969 bis heute, Macht und Verantwortung, 319-327.

${ }^{11}$ Jane E. Stromseth, The Origins of Flexible Response: NATO's Debate over Strategy in the 1960s (New York: St. Martin's Press, 1988); Francis G. Galvin, Nuclear Statecraft: History and Strategy in America’s Atomic Age (Ithaca: Cornell University Press, 2012).

${ }^{12}$ Helga Haftendorn, Sicherheit und Stabilität: Außenbeziehungen des Bundesrepublik zwischen Ölkrise und NATO-Doppelbeschluß (München: Deutscher Taschenbuch Verlag, 1986), Helga Haftendorn, Security and Détente: Conflicting Priorities in German Foreign Policy (New York: Praeger Publishers CBS Educational and Professional Publishing, 1985), Klaus Wiegrefe, Das Zerwürfnis, and Ivo H. Daalder, The Nature and Practice of Flexible Response.
} 
recent works from Leopoldo Nuti and Kristina Spohr Readman. ${ }^{13}$ Specifically Spohr Readman’s findings about the work in two NATO expert groups that prepared the dual-track decision contribute to the overall understanding of the respective national positions. She had access for her studies to several formerly classified documents that other authors-including the former leading politicians_-could not use for their respective books. The fourth section deals with the dual-track decision, itself, and the immediate consequences of the decision. The fifth section summarizes the conclusions with respect to the research question on how the dual-track decision was shaped and how much personal influence the former political leaders of Germany and the United States had on the decision. All translations from German into English for this monograph were done by the author, unless otherwise noted.

The author's thesis for this monograph is that NATO's dual track decision was a compromise, based on a general agreement within NATO to demonstrate alliance solidarity, taking different national interests and strategies into account. It offered the possibility to interpret the decisions differently and to focus primarily on the conduct of the most suitable interpretation for own, national interests. Subjective factors, like personal experience, background and attitudes of key leaders, and disagreements influenced the decision making process and the implementation of the dual-track decision to a great extent.

\footnotetext{
${ }^{13}$ Leopoldo Nuti, "The origins of the 1979 dual track decision - a survey" in Leopoldo Nuti, ed., The Crisis of Détente in Europe: From Helsinki to Gorbachev, 1975-1985 (London and New York: Routledge, 2009), 54-71. Kristina Spohr Readman, “Conflict and Cooperation in Intra-Alliance Nuclear Politics: Western Europe, the United States, and the Genesis of NATO’s Dual-Track Decision, 1977-1979,” Journal of Cold War Studies, vol. 13, no. 2 (Spring 2011): 39-89. http://www.mitpressjournals.org/ doi/abs/10.1162/JCWS_a_00137 (accessed January 15, 2014).
} 


\section{FLEXIBLE RESPONSE, DÉTENTE, AND TACTICAL NUCLEAR WEAPONS}

This section of the monograph provides the background to understand the discussions about the dual-track decision based on historical developments in NATO, the United States, and Germany. It covers mainly the period of time from 1967 to 1977. First, definitions are introduced as the basis for a general understanding of the nuclear weapons discussion in NATO. Afterwards, the decision and discussions about NATO’s Flexible Response strategic concept are analyzed. This strategic concept was valid through the entire dual-track discussion. Nevertheless, its ambiguity allowed for different interpretations. Third, the different approaches to détente in the United States and Germany are portrayed. These influenced the dual-track discussion to a great degree. Finally, the role of NATO’s tactical nuclear weapons is outlined.

\section{$\underline{\text { Nuclear weapons definitions }}$}

Before discussing nuclear weapon related issues including the dual-track decision from 1979, a certain understanding about the classification of nuclear weapons is required.

Unfortunately, there are no commonly accepted definitions available that would allow classifying every type of asset in a distinct and generally accepted way. ${ }^{14}$ For the purpose of this monograph,

\footnotetext{
${ }^{14}$ Technical criteria that are commonly in use to classify nuclear weapons refer to the respective TNT equivalent yield of a nuclear warhead and the range of a delivery asset. In this case, low yield weapons with a range of less than $500 \mathrm{~km}$ are generally considered to be tactical nuclear weapons (TNWs). Some of these weapons - like gravity bombs - can nevertheless be delivered by dual capable aircraft (DCA) or even by strategic bombers with a longer range. Modern fighter bombers that have the ability to deliver such weapons over hundreds of kilometers (i.e. more than $500 \mathrm{~km}$ ) are considered to be Theater Nuclear Forces (TNF) to the same degree as missile based systems that cover the same range. In many cases, the yield of strategic weapons that are delivered by ballistic missiles is not different from the yield of missiles with a lower range. This is the reason why many authors refuse to distinguish between SNWs and TNWs, at all. Specifically the discussion prior to NATO's dual-track decision focused on weapons of ranges from 500-5500 km. These TNF were also referred to as being Intermediate Nuclear Forces (INF). Others classify them to be Long Range Tactical Nuclear Weapons or Long Range Theater Nuclear Weapons (LRTNWs). Theater nuclear weapons were in many cases abbreviated TNWs. This can be misleading, taking different definitions into account because this abbreviation is also generally in use for the term tactical nuclear weapons. In this monograph, the abbreviation TNW will hence only be used for the latter term, the expression theater nuclear weapons will not be abbreviated unless used in direct quotes. Compare with Paul Schulte, “Tactical Nuclear Weapons in NATO and Beyond,” Tom Nichols, Douglas Stuart, and Jeffrey D. McCausland, eds., Tactical Nuclear Weapons and NATO (Carlisle: Strategic Studies
} 
definitions focusing on technical features of nuclear weapons or means of delivery are not considered to be fully suitable. A general classification into strategic nuclear weapons (SNWs) and tactical nuclear weapons (TNWs) is a conventional starting point. Strategic nuclear weapons include those that can reach U.S. soil from the Soviet Union and vice versa by ballistic missiles or assets like submarines or navy vessels and strategic aircraft. Tactical nuclear weapons are all other types—sometimes also referred to as non-strategic nuclear weapons (NSNWs). ${ }^{15}$ This rather broad distinction nevertheless proved to be insufficient during various bilateral talks and negotiations about the reduction and limitation of SNWs between the United States and the Soviet Union. Both parties could not agree for a long time about the classification of specific weapon systems. ${ }^{16}$ Various authors provided lengthy and still ambiguous definitions for different nuclear weapons. ${ }^{17}$

In Europe at the beginning of the 1970's, nuclear weapons that could cover ranges between 500 and 5,500 km were matters of particular concern. These weapons were excluded

Institute, 2012), 13-15. Also see J. Michael Legge, Theater Nuclear Weapons and the NATO Strategy of Flexible Response (Santa Monica, CA: Rand, 1983), 77.

${ }^{15}$ Schulte, 14.

${ }^{16}$ Different interpretations about strategic roles of specific types of weapon systems influenced for example the Strategic Arms Limitation Talks (SALT I and II) to a great degree. The United States considered the Soviet Backfire Bomber aircraft to be capable of reaching U.S. soil whereas the Soviet Union promoted a tactical role for this asset. The Soviets on the other hand considered U.S. cruise missiles to be capable of reaching Soviet soil and tried to include them into SALT. Daalder, 162-168.

${ }^{17}$ Schulte for instance provided a definition of TNWs as "nuclear devices and delivery systems with relatively short range and low yield by contemporary standards, which are intended for employment against conventional, or nuclear, ground, naval, air targets or transport assets, on the battlefield, or across the theater, to contribute to total conventional and nuclear campaign capability, yet which are not expected to inflict strategically decisive damage to enemy military, economic, or regime targets, but whose use would nevertheless be an unmistakable signal that the stakes in a crisis were regarded as serious enough to transform it into, or continue it as a nuclear conflict, and so, unavoidably, to risk possible escalation to a strategic level.” This long and comprehensive definition of TNWs is only partially suitable for discussing the dual-track decision. The definition covers the strategic requirements for TNWs according to NATO and Warsaw Pact military rationales during the Cold War and allows for the derivation of complementing SNW definitions. Schulte, 15. Still, Schulte's definition is not accurate enough to discuss the specific roles, SS-20 systems, Backfire bombers, cruise missiles, and Pershing II missiles had. These weapons were characterized by a specific range from 500 to $5,500 \mathrm{~km}$. 
from the Strategic Arms Limitation Talks (SALT) between the United States and the Soviet Union because they were not considered to be SNWs. At that time, Soviet SS-20 missiles were replacing obsolete SS-4 and SS-5 assets. SS-20 systems provided a range of about 5,500 km and were equipped with three nuclear warheads that could be directed to different targets. ${ }^{18}$ European NATO members—specifically Germany—considered these weapons to be eurostrategic weapons rather than TNWs because they could reach Europe from launching positions east of the Urals. ${ }^{19}$ NATO had no SS-20 equivalents available on European soil that could reach the SS-20 launching sites. Some European NATO members argued that the balance of SNWs between the U.S. and the Soviet Union allowed only for a neutralization of the respective other's strategic arsenal. They argued that none of the U.S. SNWs could target SS-20s without giving up a strategic second strike option after being attacked. ${ }^{20}$ European NATO members feared the possibility for political blackmail or at least "possibilities of intimidation during periods of tension short of war" caused by SS-20 systems. ${ }^{21}$

Nuclear weapons that could cover ranges between 500 and 5,500 km were eventually classified as intermediate nuclear forces (INF). ${ }^{22}$ These weapons were described to be in a “[sic]

\footnotetext{
${ }^{18}$ Schmidt, 92-93. According to Schmidt, SS-4 and SS-5 were stationary assets, had one warhead per weapon, could not be reloaded, and had maximum ranges of $2000 \mathrm{~km}$ and $4800 \mathrm{~km}$, respectively. The new SS-20 systems had mobile launching platforms and the SS-20 launchers could be reloaded. Though the overall numbers of SS-20 systems was still low in 1978, the production rate was considered to be eight missiles per month.

${ }^{19}$ According to a study by the RAND Cooperation, the expression eurostrategic was first used by P.M.S. Blacket in 1962. According to the RAND paper, Professor Blackett concluded that a tactical nuclear war in Europe would be considered to be strategic one by Europeans. Compare with Legge, 77.

${ }^{20}$ Compare with Schmidt, 93. Schmidt argues that only U.S. intercontinental ballistic missiles (ICBMs) could have reached eastern SS-20 launch sites. The balance between U.S. and Soviet ICBMs as the result of the SALT I treaty made it unlikely that U.S. ICBMs could have been used against SS-20 weapons.

${ }^{21}$ Schulte, 51 .

${ }^{22}$ Ibid.
} 
gray zone” because of the different perception of being TNWs or eurostrategic, respectively. ${ }^{23}$

The RAND cooperation argued in a report from April 1983 that the terms strategic and tactical historically "denoted the use of nuclear weapons, not the weapons themselves." ${ }^{24}$ Different perceptions in the Soviet Union about the classification of specific nuclear weapons eventually led to the introduction of the terms theater nuclear forces (TNF) or theater nuclear weapons, "categorizing them by location rather than role." ${ }^{25}$ In consequence, four categories of theater nuclear weapons referring to the maximum range were introduced. "Long-range theater nuclear weapons” were defined as weapons with a range exceeding $1,000 \mathrm{~km} \cdot{ }^{26}$ Still, the expression theater nuclear weapons was primarily accepted in U.S. terminology. ${ }^{27}$

Overall, the discussed definitions about classes of nuclear weapons and the various interpretations demonstrate the difficulty of finding commonly agreed terms for the same phenomena. Hence, in this monograph, various definitions and terms for nuclear weapons need to be used because official documents, political leaders and scholars use their own terminology, depending on their specific background and intentions. Schulte's distinction between SNWs as those that could reach the territory of the United States from the Soviet Union and vice versa and TNWs as all others is suitable for all discussions about NATO strategy and the bilateral discussions between the United States and the Soviet Union. The terms intermediate nuclear

\footnotetext{
${ }^{23}$ Glitman, 21.

${ }^{24}$ Legge, 77.

${ }^{25}$ Ibid.
}

${ }^{26}$ Legge, 78-79. The four categories of theater nuclear weapons were long-range theater nuclear weapons (more than 1,000 km), medium -range theater nuclear weapons (150-1,000 km), short-range theater nuclear weapons (less than $150 \mathrm{~km}$ ) and defensive systems (including Atomic Demolition Munitions [ADMs] and nuclear air defense systems but excluding antiballistic missile [ABM] systems). It must be noted that Legge recognizes the difficulty of putting sea based nuclear weapons into this categorization. Also, within the LRTNW class, some authorities use a range of more than 1,500 km.

${ }^{27}$ Helmut Schmidt refused to use the expression theater nuclear forces because he considered the term theater to be an unnecessary indicator about an intended theater of war (Kriegsschauplatz). He claims that for psychological and semantic reasons he mostly used the expression eurostrategic weapons that were threatening the German people. Schmidt, 230. 
forces (INF), long-range theater nuclear weapons (LRTNWs), eurostrategic weapons, and greyzone weapons are also in use for the weapon systems under consideration concerning the dualtrack decision. ${ }^{28}$

\section{NATO and Flexible Response}

Prior to December 1967, NATO’s strategic concept was described in the “Overall Strategic Concept for the NATO Area (MC 14/2) from December 21, 1957.”29 MC 14/2 emphasized particularly the nuclear component of NATO's defense forces and an early use of tactical nuclear weapons to counter a possible attack against NATO. Conventional forces were considered to be shield forces. Their main purpose was to set the preconditions for nuclear equipped sword forces to counterattack.

On December 12, 1967, NATO’s Defence Planning Committee adopted the Flexible Response strategic concept (MC 14/3). ${ }^{30}$ Flexible Response had its origins in the United States in the late 1950s and the early 1960's. After the Soviet Union successfully launched her Sputnik satellite on October 4, 1957, it became clear that "the Soviet Union would soon possess the capability to strike the United States homeland with intercontinental nuclear missiles.” ${ }^{31}$ The Sputnik launch led to an understanding inside the United States that "a situation of [sic] 'mutual deterrence' was evolving, in which both sides would be deterred from initiating or risking general

\footnotetext{
${ }^{28}$ The term INF was used during the negotiations for an INF treaty and is also commonly accepted in contemporary literature to a great extend. Compare with Maynard W. Glitman, The Last Battle of the Cold War (New York: Palgrave MacMillan, 2006).

${ }^{29}$ North Atlantic Military Committee, "Final Decision on MC 14/2 (Revised): A Report by the Military Committee on Overall Strategic Concept for the Defense of the North Atlantic Treaty Organization Area, May 23, 1957,” NATO, http://www.nato.int/docu/stratdoc/eng/a570523a.pdf (accessed January 20, 2014).

${ }^{30}$ North Atlantic Military Committee, "Final Decision on MC 14/3: A Report by the Military Committee to the Defence Planning Committee on Overall Strategic Concept for the Defense of the North Atlantic Treaty Organization Area, January 16, 1968,” NATO, http://www.nato.int/docu/stratdoc/eng/ a680116a.pdf (accessed January 20, 2014).

${ }^{31}$ Stromseth, 20.
} 
nuclear war because of the prospect of mutual nuclear devastation.”32 The fact that the Soviet Union was able to launch an artificial satellite into space contributed to the perception that the United States had lost her technological superiority to the Soviets. Inside the United States, the perception of a missile gap influenced the domestic political debate. ${ }^{33}$ At the same time, U.S. officials recognized that European NATO allies started doubting that the United States would use nuclear weapons to defend European soil. ${ }^{34}$ In consequence, the United States agreed to station U.S. nuclear weapons in Great Britain, Italy, and Turkey to restore the creditability of U.S. deterrence guarantees in Europe. ${ }^{35}$ In 1957, German Chancellor Konrad Adenauer requested to equip the German Bundeswehr with U.S. tactical nuclear weapons after the Sputnik shock. He considered tactical nuclear weapons to be a further development of artillery systems and argued that the Bundeswehr required the most modern weapons available to fulfill her NATO tasks. ${ }^{36}$ Adenauer's request led to the most controversial discussion in Germany after the Second World

\footnotetext{
${ }^{32}$ Ibid. Stromseth described that several members of the U.S. administration and U.S. military leaders came to the conclusion that given the Soviet capability to reach U.S soil with intercontinental nuclear missiles, the role of sword and strike forces had to be reconsidered. President Eisenhower decided in 1958 not to change the existing national security policy.

${ }^{33}$ Harald Biermann, “Stunde Höchster Gefahr, ” Spiegel Secial Geschichte, no.3 (2008): 47. Biermann reflected in more detail about the perceived armaments deficit with respect to intercontinental missiles in the United States. He stressed that John F. Kennedy used the missile gap argumentation against President Eisenhower and Republican presidential candidate Richard Nixon to a great degree. Biermann stated that Eisenhower knew that the missile gap did not exist but could not state this publicly because information about Soviet missile capabilities was classified. According to Biermann, the United States had a significant lead in intercontinental missiles in 1960 and the missile gap never existed.

${ }^{34}$ Stromseth, 20.

${ }^{35}$ Biermann, 47. He described that the Sputnik launch shocked the world and led to pressure from European NATO states towards the United States. In consequence, the United States agreed to station U.S. nuclear weapons in Great Britain, Italy, and Turkey to restore the credibility of U.S. deterrence guarantees in Europe. Stromseth stated that "American tactical nuclear weapons were stockpiled in Western Europe in increasing numbers, particularly after December 1957, reaching a total of about 2500 by the end of 1960.” Stromseth, 24.

${ }^{36}$ Axel Schild, “Das Böse Schlechthin,” Spiegel Secial Geschichte, no.3 (2008): 50-51.
} 
War. The question, whether the Federal Republic of Germany should be equipped with nuclear weapons polarized the German society in 1957-1958 to a so far unknown degree. ${ }^{37}$

The Second Berlin Crisis of 1958-1961 and the Cuba Crisis of 1962 demonstrated to the U.S. leadership that an overall nuclear reaction independent from the type of a possible aggression was no longer suitable and “convinced Kennedy that the West must have some alternative between [sic] 'holocaust and humiliation.”, 38 The Soviet Union had achieved a perceived nuclear stalemate situation and was able to reach the United States with nuclear assets. After the construction of the Berlin Wall in August 1961, and after a review of existing contingency plans for Berlin, President Kennedy decided to focus more on conventional capabilities. ${ }^{39}$ The overall goal was a more "flexible array of forces with which to respond to threats at all levels, from major military aggression to guerilla warfare in the Third World." ${ }^{40}$ In consequence, U.S. Secretary of Defense Robert McNamara tried to persuade the NATO allies to

\footnotetext{
${ }^{37}$ For a more comprehensive description of the German debate about nuclear weapons, see Schild, 50-53.

${ }^{38}$ Stromseth, viii.

${ }^{39}$ The Second Berlin Crisis started when Soviet Prime Minister Nikita S. Khrushchev gave a speech on November 10, 1958-commonly known as the Berlin Ultimatum. He called for a peace treaty with Germany, demanded the revision of the four power status of Berlin, and promoted that Berlin should become a "free city." Should these demands not be fulfilled, Khrushchev announced that the Soviet Union would transfer her occupation rights in Berlin to the German Democratic Republic. Khrushchev's speech demonstrated a new Soviet self consciousness based on the Sputnik success in October 1957. Eventually, the Second Berlin Crisis led to the construction of the Berlin wall in 1961. For a more comprehensive analysis about the discussions and subsequent consequences of the Berlin Ultimatum see Haftendorn, Security and Détente, 68-81.

${ }^{40}$ Stromseth, 29. Chapter 3 of the book provides a more detailed overview about the development of Flexible Response within the United States. The U.S. administration doubted that the threat of an overall nuclear reaction was convincing enough to deter the Soviet Union from any type of aggression. An immediate use of U.S. nuclear weapons against small scale conventional aggressions was no longer considered to be reasonable because the Soviet Union had the capability to retaliate against U.S. homeland. The credibility of the overall deterrence concept was at stake. A small, conventionally conducted aggression might have been successful if the threshold for risking an all arms nuclear conflict could have been avoided. Secretary of Defense McNamara also assessed that American nuclear forces were vulnerable to surprise attacks, non-nuclear forces lacked essential capabilities, and contingency plans were not suitable.
} 
adopt the same approach. In a speech at a meeting of NATO’s Foreign and Defense Ministers in Athens, Greece, on May 5, 1962, McNamara requested from NATO to adopt the U.S. strategy. ${ }^{41}$ It took NATO more than five years before Flexible Response was officially embraced with the MC 14/3 document. ${ }^{42}$ Continuous resistance of several NATO members demonstrated contrasting interests between Western Europe and the United States. ${ }^{43}$ Various scholars have presented their own theories and explanations about the rationale for the respective countries to have different opinions towards the U.S. approach. ${ }^{44}$ Karl Diefenbach concluded that the United States philosophy was — should deterrence fail— to have the option of limiting and ending a conflict occurring on European soil without threatening U.S. territory. ${ }^{45}$ France was the strongest opponent of the new strategic approach. The French position was that the likelihood for an

American use of strategic nuclear weapons to protect European partners from an aggressor was at

${ }^{41}$ Ibid., 42-44. It should be noted that one of McNamara's main issues was to promote a centrally controlled NATO nuclear force. He opposed nationally controlled French and British nuclear weapons to the same degree as ambitions of other NATO members to develop or procure these weapons. He spoke of a strategy of "controlled and Flexible Response," stressing the requirement for unified planning and decision making.

${ }^{42}$ North Atlantic Military Committee, "Final decision on MC 14/3."

${ }^{43}$ This led amongst other things to France’s withdrawal from NATO’s military structures before Flexible Response was adopted. Also other European NATO members opposed the new strategic concept. Germany for instance feared the loss of U.S. security guarantees and the government requested nuclear operational planning participation. The German government opposed raising the threshold for the use of nuclear weapons because the threat of a conventional war on Germany's terrain would be increased. Only after the concept of forward defense on Germany's border was guaranteed and a certain degree of nuclear participation in NATO was institutionalized, Germany overcame the reservations concerning Flexible Response. For a more detailed discussion about the German position concerning Flexible Response, see Haftendorn, Security and Détente, 103-108. Also see Karl Diefenbach, "Militärgeschichte nach dem Zweiten Weltkrieg: Vom Kalten Krieg zur Entspannung" in Grundzüge der deutschen Militärgeschichte: Band 1, 437-439. Also see Stromseth, 119-120. She concluded that France's withdrawal from NATO's integrated military structures was not directly caused by the discussions about Flexible Response. She considered the strategy discussion to be the occasion or pretext.

${ }^{44}$ Examples for that can be found in Ivo Daalder, The Nature and Practice of Flexible Response. He concluded that differences were caused to a great degree by the respective assessments concerning the requirements of extended deterrence. He described four distinct deterrence strategic approaches that were labeled as pure, escalatory, conventional, and warfighting. From there he described the contrasting positions. Daalder, 206-224. Stromseth examined in detail the French, British and German positions and respective strategic rationales. Compare with Stromseth, chapters 6-8.

${ }^{45}$ Diefenbach, 437. 
best low. The French rationale was that U.S. national interest to protect U.S. soil might outweigh alliance solidarity. Hence, President de Gaulle promoted the establishment of a French national force de frappe and specifically objected to American attempts of centrally controlling NATO nuclear assets. Consequently, France withdrew from NATO’s integrated military structures in 1966. $^{46}$

Many European NATO partners favored enhancing the risk of escalation to the highest possible degree to prevent any form of aggression against their territory. Tactical nuclear weapons stationed close to the Iron Curtain were considered to be a means compelling the Soviet Union to assume that NATO would use them. A possible conflict would then provide another qualitative, quantitative and geographical dimension to the aggressor. ${ }^{47}$ In the end, NATO overcame the opposing views by emphasizing conventional deterrence to a higher degree, and by institutionalizing the participation of European NATO partners within a Nuclear Planning Group (NPG) and the NATO Nuclear Defense Affairs Committee (NDAC).$^{48}$ For a stake in nuclear

\footnotetext{
${ }^{46}$ Compare with Stromseth, 96-120. She mentioned that some scholars came to the conclusions that the Suez Crisis in 1956 led France to the conclusion that the United States could not be trusted in the future to support her NATO allies' vital interests unless they matched American interests. In consequence, France decided to build up her own deterrence capability that she could use to support NATO interests when appropriate, but she would not assign under NATO control. Additionally, she argued that without France's withdrawal from NATO’s integrated military structures, Flexible Response would have never been adopted by NATO. This was due to the fact that the required consensus would have been prevented by France's objections to the military strategic concept binding her own forces.

${ }^{47}$ Diefenbach, 437. Diefenbach's explanation was chosen though this thesis is not fully supported by all scholars, for example Stromseth. Diefenbach's approach provides nevertheless a specific rationale from a German point of view that will be helpful to understand the discussion about NATO's dual-track decision. German politicians were generally concerned about U.S. motivations and the possibility that the United States could focus on keeping own terrain unharmed by limiting a potential warzone to Europe, should the overall concept of deterrence fail. The fear of decoupling American from West European security interests was one of the most important arguments en route to the dual-track decision. Ivo Daalder acknowledged these arguments in his book. A general description about German Foreign Policy and underlying rationales can be found in Haftendorn, Security and Détente, 10-19. Also compare with Schmidt, Menschen und Mächte.

${ }^{48}$ Diefenbach, 437. The NPG was founded in 1966 to establish a consultative process on nuclear doctrine within NATO. To facilitate the NPG's work, the United States, the United Kingdom, Italy and Germany became permanent members. Additionally, three seats rotated on a yearly basis between nations participating in NATO's integrated military structures. The NDAC included all NATO members. Facts are
} 
planning, which for many European NATO partners was an area of great concern, the European NATO partners less France were willing to accept U.S. proposed language which suggested a broadening of the range of deterrent options. Nevertheless, the European NATO partners remained deeply ambivalent of moves to return to symmetric containment in the vein proposed by the Truman administration at Lisbon in $1952 .{ }^{49}$

The agreed language of MC 14/3 described general possibilities to respond to an attack within the framework of Flexible Response. The initial response to any aggression, with the exception of a general nuclear attack, was labeled direct defense. This meant a military response at the chosen level of aggression—-be it conventional or nuclear. If the direct defense measures were not sufficient, NATO was willing to conduct a deliberate escalation-including the first use of nuclear weapons - to contain the aggression and restore the situation. A general nuclear response would counter a major nuclear attack. ${ }^{50}$ The available categories of means were described as a triad compromised of strategic nuclear weapons, tactical or theater based nuclear weapons, and conventional forces each of which had a role within the given responsive options. Internally, this rather vague and ambiguous description left enough space for different interpretations of the respective NATO members. Accordingly, nations stressed different

taken from the official NATO website, www.nato.int/cps/en/natolive/topics_50069.htm (accessed on December 3, 2013).

${ }^{49}$ For the internal discussion in Germany see Diefenbach, 435-439. Originally, the German Bundeswehr was tasked to provide 500,000 conventional forces to symmetrically counter Soviet conventional forces in Central Europe. After the principle of Massive Retaliation was introduced in NATO's strategic concepts, the rationale for providing these 500.000 forces was under question. In consequence, Germany aimed for a participation in NATO's strike forces since 1957 by requesting a limited nuclear participation. When NATO's Flexible Response discussion started at the beginning of the 1960's, the German government and the armed forces felt equally uncertain, how to proceed. A role for the Bundeswehr as suggested in Lisbon 1952 was no longer considered to be sufficient concerning political influence and military significance within the alliance. In consequence, Germany requested nuclear planning participation to the same degree as formally establishing the principle of forward defense as a precondition to accept Flexible Response. Still, the German Air Force focused until the end of the 1960's on its strike force tasks.

${ }^{50}$ Stromseth, 175. 
consequences and justifications for agreeing to the new strategic concept. Germany stressed the importance of a comprehensive and interconnected cooperation of European and American military capabilities in combination with a suitable flexible strategy. Western Europe’s separation from U.S. nuclear guarantees had to be avoided. ${ }^{51}$ Germany's position was that the three possible types of reaction—direct response, deliberate escalation and general nuclear response—should not be interpreted as 'providing for a triad of responses in distinct [sic] 'phases,' in which nuclear use would occur only when conventional defences were about to collapse.”52

Another important difference between European and American interpretations of Flexible Response can be observed by the way the strategic concept was addressed. U.S. scholars tend to focus on MC 14/3 as the relevant strategic paper of NATO’s Military Committee (MC) though acknowledging that "Flexible Response was a compromise in both military and political terms."53 In many European papers and official documents, MC 14/3 is usually mentioned in conjunction with the so called Harmel Report, providing the political framework for Flexible Response. The Belgium Minister of Foreign Affairs Pierre Harmel led a NATO working group and presented a paper to the NATO Defense Ministers in December 1967 titled "Report of the Council on the Future Tasks of the Alliance.” 54 The Harmel Report “introduced a new dimension, committing the Alliance to a dual-track policy: it advocated the need to seek a relaxation of tensions of EastWest relations while maintaining adequate defence, i.e. military defence, deterrents would be

${ }^{51}$ Diefenbach, 439. Also see Stromseth, 177.

${ }^{52}$ Stromseth,176-177.

${ }^{53}$ Stromseth, 176. The political component referred primarily to the political understanding of the role of conventional forces as opposed to European perspectives that the strategic concept could only be seen in conjunction with the results of the Harmel Report. Flexible Response was officially endorsed by NATO in May 1967. MC 14/3 was nevertheless finalized on January 16, 1968, after the endorsement of the Harmel Report took place in December 1967.

${ }^{54}$ NATO, "Report of the Council on the Future Tasks of the Alliance, December 1967,” NATO, http://www.nato.int/cps/en/natolive/80830.htm (accessed December 4, 2013). 
balanced alongside political détente.”55 The Harmel Report provided NATO with a new understanding that security could be achieved by a combination of the capability for defense on one hand, and détente on the other. This new double-strategy defined a new role for NATO within the initiated process of détente in Europe. ${ }^{56}$

In the 1970s, NATO’s cohesion was challenged. In the United States, the Vietnam War as well as the Watergate affair and the eventual replacement of President Nixon by President Ford were the dominant subjects. These affected the perception of the United States in Europe to a great degree. After France left the integrated military structures, the Greek-Turkish conflict about Cyprus threatened to unravel the alliance's southeastern flank. Later, Spain and Portugal caused frictions in West Europe. ${ }^{57}$ Additionally, internal security challenges within NATO member states required a greater focus than alliance security. In Great Britain, the Irish Republican Army conducted a civil war in Northern Ireland and attacked British governmental institutions. In Italy, the Red Army Brigade conducted terrorist attacks to the same degree as the Baader-Meinhoff Gang and the Red Army Faction in West Germany. ${ }^{58}$ Nevertheless, Flexible Response in conjunction with the Harmel Report remained the cornerstone of NATO and its members for

${ }^{55}$ NATO, “The Harmel Report,” NATO, http://www.nato.int/cps/en/natolive/topics_67927.htm (accessed December 4, 2013). This report stressed NATO’s twin functions as political and military.

${ }^{56}$ Hans-Adolf Jacobsen, Uwe Heuer and Hans-Jürgen Rautenberg, ed., Friedensicherung durch Verteidigungsbereitschaft: Deutsche Sicherheitspolitik 1949-1989 (Mainz: v. Hase \& Köhler Verlag, 1989), 112.

${ }^{57}$ Greece left NATO’s integrated military structures in 1974 as a result of the Turkish invasion of Cyprus. For Portugal and Spain see Schmidt, 206-211. Schmidt described a conversation between President Ford, Secretary Kissinger and himself about Spain and Portugal on May 29, 1975. Though Spain was not a NATO member before 1982, her geographic position was of great interest to NATO. Spain was still ruled by her dictator Francisco Franco in 1975. The questions the U.S. and German delegation discussed was about possible successors for Franco and what consequences could be expected for NATO. Portugal at that time had experienced a coup in 1974. The military showed solidarity with the new socialist-communist government. In the mid 1970s, the Soviet Union’s influence on Portugal was a main issue.

${ }^{58}$ For a more detailed description of the influence of the Red Army Faction and the BaaderMeinhoff Gang in Germany see Soell, Helmut Schmidt: 1969 bis heute, Macht und Verantwortung, 640690. 
common security policy. Still, the emphasis of deterrence and détente differed between NATO partners and led to varying interpretations about ways and means to achieve them.

\section{Conclusions from Flexible Response}

With respect to the dual-track decision of 1979, the discussions about Flexible Response led to the following conclusions. First of all it became clear that the United States and the European NATO partners had different strategic conceptions concerning a possible future war. The United States concluded from the perception of mutual assured destruction (MAD) that the immediate use of strategic nuclear weapons to counter any type of aggression was no longer feasible. ${ }^{59}$ A conflict in Europe required suitable conventional forces to initially counter the threat on an appropriate level before using nuclear weapons. The exclusion of U.S. territory from small conflicts could be assumed by the new strategic approach. Still, U.S. leadership in NATO and U.S. NATO integration were considered to be crucial to retain the global balance.

European NATO members—with the exception of France—-had a general interest in connecting their security as close as possible to the security of the United States. They wanted to prevent any conflict on European soil to the greatest possible degree. The most suitable strategic concept was one that would put an aggressors risk as high as possible independent from the initial aggression level. At the same time, Europeans wanted the United States to remain NATO’s lead nation and retain the transatlantic partnership guaranteeing their security. These factors led to a strategic compromise allowing for ambiguous interpretations about possible execution.

The discussions and consequent compromise about Flexible Response strengthened the influence of smaller, non-nuclear power nations — to include Germany—within NATO. The establishment of the Nuclear Planning Group provided those nations with a forum to participate

\footnotetext{
${ }^{59}$ For a description of the expression mutual assured destruction (MAD) see Gavin, Nuclear Statecraft, 107.
} 
actively in nuclear alliance policy and decision making. The endorsement and emphasis of the Harmel Report demonstrated the new influence of smaller nations on the overall alliances strategic concept. This paved the way for more self-consciously national approaches in the future. The ambiguous formulation about the principles of deterrence and détente led to different approaches and interpretations about their specific conduct.

\section{Détente}

After the Cuban missile crisis, a cautious détente developed between the United States and the Soviet Union. Both states pursued policies of balance of power. At the same time, both powers tried to prevent positional gains of the opposing side while promoting own security, economic and prestige related interests. ${ }^{60}$ The respective areas of influence were recognized. For instance, the Soviet Union refrained from direct intervention in Vietnam and the United States de facto accepted the Soviet breakup of reforms in Czechoslovakia in 1968. Also, both powers were able to cope with the consequences of the 1973 Yom Kippur War without confronting each other directly. The two global powers came to certain agreements on commonly shared interests. They aimed at reducing the risk of a global nuclear conflict and the prevention of nuclear weapon proliferation.

On July 1, 1968, the United States, the Soviet Union and the United Kingdom signed a nuclear non-proliferation treaty. ${ }^{61}$ After an assured strategic second strike nuclear capability was reached, both global powers agreed on their willingness for arms limitations. Subsequent bilateral Strategic Arms Limitation Talks (SALT) from 1969 to 1972 resulted in the signing of the SALT I treaty on May 26, 1972. Both sides agreed for the first time about an upper limit on the number of

\footnotetext{
${ }^{60}$ Compare with Diefenbach, 438. Also compare with Friedenssicherung durch Verteidigungsbereitschaft, 111.

${ }^{61}$ Friedenssicherung durch Verteidigungsbereitschaft, 111, and 370. The Federal Republic of Germany signed the treaty on November 28, 1969, after Willy Brandt was elected as German Chancellor. Friedenssicherung durch Verteidigungsbereitschaft, 181, 207-209, and 371.
} 
strategic nuclear weapons either side was allowed for five years. Additionally, an Anti-Ballistic-

Missile (ABM) Treaty was included in SALT I. It limited the amount of defensive systems

against SNWs. ${ }^{62}$ Following the signing of the SALT I treaty, negotiations about an even more

comprehensible SALT II treaty commenced. SALT II was eventually signed in $1979 .{ }^{63}$

On June 22, 1973 the United States and the Soviet Union signed an agreement on the prevention of nuclear war. ${ }^{64}$ On October 30, 1973 official talks on Mutual and Balanced Force Reductions (MBFR) commenced in Vienna. They aimed on an agreement about limitations on conventional arms and armed forces on the territories of West and East Germany, the Netherlands, Belgium, Luxembourg, Czechoslovakia, and Poland. Represented were all before mentioned states as well as the United States, the United Kingdom and the Soviet Union. ${ }^{65}$ On August 1, 1975, the Helsinki Final Act of the Conference on Security and Cooperation in Europe (CSCE) was signed by 35 participating states including Canada, the Soviet Union, and the United

\footnotetext{
${ }^{62}$ A detailed description of the SALT I treaty and the ABM treaty can be found in Erin R. Mahan and Edward C. Keefer, eds., Foreign Relations of the United States: 1969-1976, Vol. 32, SALT I, 19691972 (Washington, DC: U.S. Government Printing Office, 2010), http://www.static.history.gov/frus/frus1969-76v32/pdf/frus1969-76v32.pdf (accessed December 17, 2013).

${ }^{63}$ Carter, 260. After the treaty was signed and the Soviet Union invaded Afghanistan in December 1979, the ratification process was stopped. A more detailed description can be found in the fifth section of this monograph.

64“'Agreement between the United States of America and the Soviet Socialist Republics on the Prevention of Nuclear War, Washington: June 22, 1973,” http://www.fas.org/nuke/control/prevent/ text/prevent1.htm (accessed December 17, 2013).

${ }^{65} \mathrm{~A}$ comprehensive description about MBFR and resulting difficulties to achieve any consensus can be found in Donald L. Clark, "What's an MBFR?” Air University Review (July-August 1976), http://www.airpower.maxwell.af.mil/airchronicles/aureview/1976/jul-aug/clark.html (accessed December 17, 2013). It should also be noted that certain types of TNWs were included in the MBFR negotiations, though without a final result. Also see Haftendorn, Sicherheit und Stabilität, 137-139. Haftendorn explained the German rationale and expectations from the MBFR negotiations. The overall target of reducing the amount of troops in Europe to 700,000 respectively in two phases could not be reached. The Western participants requested "common collective ceilings," meaning that NATO and the Warsaw Pact could decide themselves about the national composition of these troops. Germany was the strongest supporter of this approach because otherwise the strength of the Bundeswehr would have been restricted by a binding treaty. The biggest obstacle from the Western point of view to achieve such a parity agreement was that the numbers of troops that had to be reduced in East Europe could not be clarified. NATO assessments about Warsaw Pact strengths differed substantially from the numbers, the Eastern delegations presented while the talks took place.
} 
States. ${ }^{66}$ Overall, all these détente related measures were considered to be in line with NATO’s policy as outlined in the Harmel Report.

Helmut Schmidt described in his memoirs President Nixon’s and President Ford’s approaches towards NATO. He came to the conclusion that the commonly defined “alliance’s double grand strategy" remained valid in both presidencies. ${ }^{67}$ The two pillars Schmidt referred to were common security against the Soviet Union, provided by common defense capabilities, and cooperation with the Soviet Union, specifically by means of arms limitations through SALT and MBFR. ${ }^{68}$ The United States hence pursuit its own, globally oriented détente approach. Bilateral attempts between the United States and the Soviet Union for cooperative armaments control were at the core of this globally conducted détente. The participation in MBFR talks offered European states like the Federal Republic of Germany a limited possibility to participate directly in the previously bilaterally conducted dialogue. Though in the United States the MBFR talks were not considered to be equally important as, for instance, SALT negotiations, MBFR linked global détente measures with European, regionally focused détente initiatives. ${ }^{69}$

\section{German détente, the Ostpolitik}

Since 1966, the Federal Republic of Germany was governed by a grand coalition, compromised of the conservative Christian Democratic Union/Christian Social Union (CDU/CSU) and the Social Democratic Party. For the first time after the Second World War, the

${ }^{66}$ The CSCE talks started on July 3, 1973 and attempted to improve political relations between the Western and Eastern alliances in Europe. Though the final act did not have the binding character of a treaty, the accord provided a written statement, signed by the respective heads of government, about the inviolability of frontiers, sovereignty rights and the recognition of human rights as well as the right for selfdetermination. The full text can be reviewed at University of Minnesota Human Rights Library, "The Final Act of the Conference on Security and Cooperation in Europe, Aug 1, 1975, 14 I.L.M. 1292, Helsinki Declaration,” http://www1.umn.edu/humanrts/osce/basics/finact75.htm (accessed December 17, 2013).

${ }^{67}$ Schmidt, 206.

${ }^{68}$ Ibid.

${ }^{69}$ Haftendorn, Sicherheit und Stabilität, 134-139. 
SPD was not in an oppositional role. Willy Brandt became Germany’s Foreign Minister. ${ }^{70}$ In 1969, the Social Democrats won the parliamentary elections and established a coalition with the liberal Free Democratic Party (FDP) to form the first SPD led government of the Federal Republic of Germany. Willy Brandt became Federal Chancellor. At that time, the Social Democrats had long accepted West Germany’s integration into the Western alliance and given up their neutralist tendencies. The party itself had developed from a class party to a people's party after the Godesberg program of $1959 .^{71}$ The specific German understanding of the security environment was gradually shaped by an understanding that a cautious process of détente between the two blocs took precedence over changing the so-called German question. ${ }^{72}$

\footnotetext{
${ }^{70}$ Willy Brandt was a leading member of the SPD. From 1957 to 1966 he was Berlin’s Governing Mayor. President Kennedy visited Berlin in 1963 and gave his famous speech in which he said "Ich bin ein Berliner.” In 1961, Brandt was the SPD's leading candidate to become German Chancellor but he lost the public elections against Konrad Adenauer and the CDU. Brandt became chairman of the SPD in 1964. In 1965, he was again leading candidate of the SPD and lost against Ludwig Erhardt, CDU, who succeeded Adenauer as Chancellor of the Federal Republic of Germany. From 1966 to 1969, Brandt was German Vice-Chancellor and Minister of Foreign Affairs under Chancellor Kurt Kiesinger, CDU. Brandt became Federal Chancellor from 1969 to 1974. Brandt resigned as Chancellor after the so-called Guillaume affair. Günter Guillaume was a close aide to Chancellor Willy Brandt and finally revealed to be an East German spy. Brandt remained chairman of the SPD until 1987. For a more comprehensive biography of Willy Brandt see www.deutsche-bundeskanzler.de/brandt_willy.shtml (accessed February 5, 2014). For a more detailed description about Brandt's resignation, see Soell, Helmut Schmidt: 1969 bis heute, Macht und Verantwortung, 319-327.

${ }^{71}$ Compare with Jeffrey Herf, War by other Means: Soviet Power, West German Resistance, and the Battle of the Euromissiles (New York: The Free Press, 1991), 15-26. At the beginning of the young Federal Republic of Germany, many Social Democrats "envisioned a neutralist, united, democratic, and socialist Germany.” Herf, 22. Still, under the leadership of Kurt Schumacher, the democratic left party opposed Communism and considered itself to be "the bulwark against communism." Herf, 22. After 1959, "it was apparent to the leaders of the Social Democratic party that class struggle in domestic politics and neutralism in foreign policy were recipes for continued national electoral defeat. In 1959, at its historic party congress in Bad Godesberg, the SPD officially became a [sic] Volkspartei, a people's party seeking support from all social and economic groups, in contrast to a class party.” Herf, 25.

${ }^{72}$ Friedensicherung durch Verteidigungsbereitschaft, 111-112. Before the emergence of détente as a guiding principle after the Cuban Missile Crisis and the Second Berlin Crisis, any German government and the governments of the United States and the Soviet Union focused to a great degree on the status of the two German states, their respective integration into the Warsaw Pact and NATO, and on the question of whether or how to achieve an eventual reunification-also referred to as the German question. In the 1960's the principle of balance of power and the understanding of the possibility of mutual assured destruction (MAD) led to an understanding of peaceful co-existence between the two powers United States and Soviet Union. The status quo within Europe would not be challenged actively by both major powers, practically accepting the respective spheres of influence. The focus was drawn away from Europe towards
} 
The German security policy of the time was shaped by the continuation of the East-West conflict. The primacy of conflict avoidance and providing deterrence to the same degree as the capability for dialogue was considered to be mandatory. ${ }^{73}$ As a consequence, Germany developed her own approach towards détente with her eastern neighbors and the Soviet Union. ${ }^{74}$ This policy is commonly known as the German Ostpolitk. German reunification no longer seemed possible within the foreseeable future. Taking into account the security related circumstances of mutual assured destruction and the necessity for peaceful coexistence other ways had to be determined to eventually achieve reunification. A Wandel durch Annährerung (change through rapprochement) approach took into account that German reunification might remain possible "only with the Soviet Union” taking the Soviet military strength fully into account. ${ }^{75}$ As Egon Bahr of the SPD put it "[t]he major aim of the Soviet Europe policy was the legalization of the status quo. The major aim of our policy is overcoming the status quo." ${ }^{76}$ In practice, this meant "forms of interactions that were short of actual formal relations” to improve the living standards of the Germans in the Eastern zone., ${ }^{77}$ Bahr argued that "a policy of economic and political pressure

the periphery without directly confronting each other. The wars in Vietnam and in Africa are examples for this. Compare with Somerseth, Diefenbach, 425-435, and Wiegrefe, 25-33.

${ }^{73}$ Friedensicherung durch Verteidigungsbereitschaft, 111.

${ }^{74}$ This led the SPD leadership amongst other things to the conclusion that Adenauer's reunification by strength approach, which was still valid in Erhardt's time as Chancellor, had to be replaced by a different approach. German reunification was never given up by any German government. Still, this new approach required a different diplomacy towards East European states. At the same time, the recognition of the GDR as a sovereign state was excluded. Also see Haftendorn, Sicherheit und Stabilität, 134. She stressed that after the Cuba Crisis of 1962, and first agreements about armaments restrictions in the 1960s, Europeans identified own possibilities and compulsions for détente measures. She claimed that after 1969, regional and global détente initiatives completed each other or were interlinked to each other.

${ }^{75}$ Egon Bahr, "Vortrag in der Evangelischen Akademie in Tutzing am 15. 7. 1963,“ in Peter Brandt and Herbert Ammon, Die Linke und die nationale Frage (Hamburg: Rowohlt, 1981), 235, quoted in Herf, 32. Egon Bahr (SPD) was then director of the Foreign Ministries Planning Staff.

${ }^{76}$ Egon Bahr quoted in Gottfried Niedhart, "Politik am heissen Draht,” in "Der Kalte Krieg, Wie die Welt das Wettrüsten überlebte, special issue,“ Spiegel Special: Geschichte, no. 3 (2008): 84.

${ }^{77}$ Herf, 33. Formal relations were in so far out of the question as that the German Democratic Republic was not acknowledged by West Germany as a sovereign state according to international law. 
directed against the Communist regime would only strengthen that Stalinist regime and deepen the division of the nation."78

Consequently, a German-Soviet Treaty was signed on August 12, 1970, a German-Polish Treaty on December 7, 1970, and a Basic Treaty (Grundlagenvertrag) with East Germany on December 21, $1972 .^{79}$ This approach led to certain critique within the Alliance and specifically in the United States stressing that Brandt's Ostpolitik and his specific emphasis on peace instead of freedom would contradict the alliance’s overall strategy. ${ }^{80}$ Additionally, Germany introduced this new policy to her allies in a more self-conscious way then before. ${ }^{81}$ This is in line with the findings of the previous sub-chapter about Flexible Response and the fact that smaller European nations became more assertive and hence more independent in conducting policy. ${ }^{82}$

Germany drew different conclusions from the Harmel Report concerning détente than the United States. After the German question was no longer considered to be the driver for East-West security relations, Germany developed her own approach towards her Eastern neighbors and the

Brandt’s government was careful not to recognize the GDR as a sovereign state. Also see "1955: Die Hallstein-Doktrin.”

${ }^{78}$ Herf, 33.

${ }^{79}$ Friedensicherung durch Verteidigungsbereitschaft, 371-372. The correct German titles of these three treaties were "Deutsch-sowjetischer Vertrag,“ "Deutsch-polnischer Vertrag,“ and "Vertrag über die Grundlagen der Beziehungen zwischen der Bundesrepublik Deutschland und der Deutschen Demokratischen Republik.”

${ }^{80}$ For a discussion of these critiques compare with Herf, 27-44. Also see Niedhard, 86. He described that President Nixon considered Ostpolitik to be dangerous and based on socialist thinking. Wiegrefe on the other hand concluded that worries about the reliability of the United States were a major motive for the establishment of the German Ostpolitik. He even referred to Helmut Schmidt, then Minister of Defense, who stated that Germany could not depend without alternatives on the functionality of an alliance in a process of obtaining "shallowness." Wiegrefe, 37.

${ }^{81}$ Egon Bahr described how he discussed the new German approach with Henry Kissinger in 1969 after the election in Germany. When Kissinger finally objected to the overall idea, Bahr answered that "we have thought it through and we are going to do it. I have not come here to consult but to inform." Egon Bahr "Wir haben Freiräume geschaffen," in "Der Kalte Krieg: Wie die Welt das Wettrüsten überlebte," Spiegel Special: Geschichte, no. 3 (2008): 91.

${ }^{82}$ Wiegrefe referred to an "end of the golden age" of transatlantic relations. He stated that the Federal Republic of Germany had been a perfect ally of the United States prior to the 1960's. This situation changed with President Kennedy and later President Johnson. Wiegrefe, 25-32. 
Soviet Union. The main aim was to keep open the possibility for a future reunification. The improvement of the quality of life in East Germany was considered to be a feasible way of avoiding a mental separation of the German people. In Germany, these measures were interpreted to be fully in line with the guiding principles of the Harmel Report. These regionally limited détente measures added to Germany’s participation in broader initiatives like the MBFR talks or the CSCE talks. At the same time, Germany fulfilled her obligations concerning the deterrence pillar of NATO’s strategy. She provided the bulk of conventional forces in Central Europe. Also, Germany hosted more U.S. tactical nuclear weapons than any other allied European state. Still, the Ostpolitik was criticized especially in the United States. The U.S. fear of German neutralism and suspicions about the connection of German Social Democrats and Soviet communists added to a different understanding of détente.

The German rationale for continuing the Ostpolitk and U.S. concerns about it influenced the discussion on the dual-track decision of 1979 to a great degree. Though Helmut Schmidt was not the architect of the Ostpolitik, he was nevertheless convinced about the general approach. Even after Schmidt became Federal Chancellor, Willy Brandt and Egon Bahr remained his powerful rivals within the German SPD. Internal social democratic rivalry and other domestic problems en route to the dual-track decision are discussed in the next section of this monograph in more depth.

\section{Tactical Nuclear Weapons in Europe}

The origins of NATO's deployment of TNWs in Europe can generally be seen in the context of the Korean War, and the concern that the Soviet Union might attempt to invade Western Europe. At a NATO meeting in Lisbon in February 1952, "the Allies sought to establish 
a force level that would provide NATO with the ability to defeat a Soviet land grab.” ${ }^{\text {}}$ Measures eventually included the rearmament, the integration of West Germany into NATO 1955, and the decision to field "the most modern weapons"- this meant nuclear weapons—in Europe. ${ }^{84}$ Large numbers of U.S. TNWs were deployed into Europe during 1953-55.

The Soviet Union conducted her first nuclear test in 1949 and began building up her own stockpiles, though she "lagged in nuclear weapons technology and could not set aside nuclear weapons for tactical purposes during this period.” ${ }^{\text {85 }}$ After President Eisenhower assumed office in 1953, the dependence on nuclear weapons in the U.S. increased. Eisenhower regarded "nuclear weapons as a strategically acceptable and decisively cheaper alternative to conventional forces.”86 NATO adopted MC 14/1 in December 1952. ${ }^{87}$ By 1960, some 3,000 TNWs were available in Europe to defend NATO. Nuclear weapons were considered to be "just another kind of military option." 88

Germany's role with respect to TNWs in the early phase of her NATO membership was unique. After 1955, Germany was to provide 500,000 conventional forces in Central Europe. A nuclear armament of the German Bundeswehr was not planned. West Germany was convinced

${ }^{83}$ Glitman, 6.

${ }^{84}$ Ibid., 7. Originally, NATO attempted to increase primarily conventional forces in Europe. The ambitious goals could nevertheless not be achieved and additional U.S. attempts to reduce defense budgets led to the conclusion that nuclear weapons would be suitable for defense and deterrence purposes.

${ }^{85}$ Schulte, 20.

${ }^{86}$ Ibid., 21.

${ }^{87}$ NATO, "North Atlantic Military Committee Decision on M.C. 14/1: A Report by the Standing Group on Strategic Guidance, December 9, 1952,” NATO, http://www.nato.int/docu/stratdoc/eng/a521209a.pdf (accessed January 20, 2014). For the differences between MC 14/1 and MC 14/2 see Diefenbach, 436-37.

${ }^{88}$ Schulte, 23. This understanding of TNWs changed only slightly over the next years in Germany. In 1967, Minister of Defense Dr. Gerhard Schröder responded to a question whether the strategy of Flexible Response would increase the risk of turning big parts of the Federal Republic of Germany into a battlefield. He stated that the firepower of modern conventional weapons led to the conclusion that any type of war would cause this effect. Compare with Friedenssicherung durch Verteidigungsbereitschaft, 125. 
that only the integration into the Western alliance would guarantee her existence, prevent the Soviet Union from attempting to occupy her terrain, and eventually lead to a suitable possibility of German reunification. Germany’s terrain, both east and west of the Iron Curtain was considered to be the primary battlefield of a future confrontation between the two blocs. The experience of the Second World War led to complex political and societal discussions to the same degree as security concerns. Germany requested for political reasons forward defense at her border, excluding the military possibility to sacrifice space for operational reasons. This caused serious problems for the alliance’s defense planning. West Germany’s conventional forces were required in Central Europe to counter the Soviet divisions as shield forces. ${ }^{89}$

West Germany’s main goal was to maintain the integrity of her terrain and avoid occupation. Any war on her terrain needed to be avoided, having experienced the devastation caused by a conventional war only a few years ago. This led to a strategic approach supporting the option for an immediate use of nuclear weapons against any aggression as the means of greatest possible deterrence. Chancellor Adenauer promoted a policy of strength (Politik der Stärke) against the Soviet Union as the appropriate means to achieve German reunification. At the same time, Germany abstained from developing her own nuclear weapons. ${ }^{90}$ Still, Adenauer “considered TNWs as practically normal weapons." ${ }^{91}$ At the latest in 1957, and as a result of the Sputnik shock, he requested an additional armament of the German Bundeswehr with nuclear

\footnotetext{
${ }^{89}$ The Soviet Union had a large superiority in conventional land forces in Europe. Building up sufficient NATO forces without a German contribution to counter these forces would have been too expensive. The Korean War tied many U.S. forces and the French Army was engaged in Indochina. These factors led specifically in the United States to the conclusion to use the German military potential. The Paris Treaties of October 23, 1954 called amongst other things for 500,000 German forces and West Germany's admission into NATO. For a more comprehensive description see Diefenbach, 425-431.

${ }^{90}$ For a more thorough analysis about Germany's policy and a discussion about her unique role with respect to TNWs, compare with Schulte, 27-29, and Friedenssicherung durch Verteidigungsbereitschaft, 25-32. At the nine power conference in London on October 6, 1954, Germany signed the final communique that included the declaration of the German Chancellor, to abstain from manufacturing nuclear, chemical and biological weapons. Friedenssicherung durch Verteidigungsbereitschaft, 49-50.

${ }^{91}$ Schulte, 28.
} 
carrier systems to enable Germany's participation in the strike forces as depicted in MC 14/2. The NATO council opted in December 1957 for a two-key-system, meaning that nuclear warheads would remain in U.S. possession but the Bundeswehr would provide dual purpose carrier systems that could be used in the event of a war to deliver conventional and nuclear warheads. ${ }^{92}$

The discussion about Flexible Response both in the U.S. and later in NATO led to a new role of TNWs. Originally, Secretary of Defense McNamara did not consider TNWs to be the weapon of choice for the future strategic concept. ${ }^{93}$ In the NATO discussions between 1962 and 1967, TNWs were retained in the concept and became an option for the deliberate escalation phase within Flexible Response. This included the option of a first use of tactical nuclear weapons to contain the aggression and restore the situation. ${ }^{94}$ In the 1970 s, more than 7,300 NATO TNWs were deployed all over Europe "of which some 2,800 were designated for [European] allied use.” ${ }^{95}$ Overall, TNWs were an established part of NATO’s strategy as well as its weapons arsenal in the 1970s.

\footnotetext{
${ }^{92}$ Diefenbach, 437-438.

${ }^{93}$ Stromseth, 45-46. According to her, McNamara saw their role primarily to deter the Soviet Union from using own TNWs. Still, he objected to the first use of TNWs because this would consequently lead to an escalation to global nuclear war without providing an advantage. He emphasized the requirement for stronger conventional forces to counter conventional led aggressions.

${ }^{94}$ Stromseth described the main reason to retain TNWs from McNamara's point of view. This was the fact that these weapons already existed in high numbers in Europe and any withdrawal would lead to the European perception of a reduced U.S. commitment in Europe. Additionally, he stressed the deterrence function against the first use of Soviet TNWs and also non-nuclear aggressions. Compare with Stromseth, 60-61. In addition to that, the required level of conventional forces as proposed in the beginning of the Flexible Response discussion was hardly achievable given budget constraints in the U.S. and in Europe. For a detailed analysis compare with Gavin, Nuclear Statecraft, 30-56.

${ }^{95}$ Steven Pifer, “NATO, Nuclear Weapons and Arms Control,” Brookings Arms Control Series Paper 7 (July 2011): 6, http://www.brookings.edu/ /media/research/files/papers/2011/7/19\%20arms\% 20control\%20pifer/0719_arms_control_pifer.pdf (accessed January 21, 2014).
} 


\section{TO THE DUAL-TRACK DISCUSSION}

\section{Initial political positions in the United States and Germany 1977}

After the Harmel Report and MC 14/3 had been adopted by NATO in 1967, NATO’s NPG discussed the transformation of nuclear doctrine to make Flexible Response operational over the next ten years. In the United States, several technological developments—for example, precision guided ammunition, enhanced radiation warheads, and long-range cruise missilesallowed for the modernization of nuclear systems. The United States promoted the requirement for a more stable conventional balance in Europe by requesting an increase of defense spending of her European allies. TNWs were considered by the United States as defensive weapons, providing level appropriate deterrence. SNWs fulfilled the role of the ultimate deterrent. ${ }^{96}$ The SALT II negotiations were at the center of U.S. arms limitations interests. Non-strategic weapons were excluded from the talks. ${ }^{97}$ In Germany, Helmut Schmidt had identified the Soviet intermediate range ballistic missile SS-20 systems as a strategic threat towards Europe. He appealed to President Ford to include these weapons into the SALT negotiations. ${ }^{98}$

The decreasing parity of long-range theater nuclear forces (LRTNF) in Europe was widely recognized. While NATO relied mainly on F-111 and Vulcan bombers, the Soviet Union

\footnotetext{
${ }^{96}$ Spohr Readman, 43-45.
}

${ }^{97}$ Still the definitions of strategic and non-strategic weapons were long disputed between the Soviet Union and the United States. Particularly the classification of the new Soviet Backfire bombers and U.S. cruise missiles were a challenge. Compare with Daalder, 163-166. Daalder claimed that Secretary of State Kissinger insisted on cruise missile development against opposition from the Pentagon in 1973. Kissinger considered these weapons as appropriate "bargaining chips" against the Backfire. Daalder, 164.

${ }^{98}$ Schmidt, 212. Schmidt described that he discussed the SS-20 issue with President Ford in May 1975. According to Schmidt, Ford promised him "expressly" to include SS-20 and Backfire bombers in SALT II. The upcoming pre-elections and presidential elections in the United States caused President Ford to delay SALT II negotiations. According to Schmidt, Ford feared that an earlier treaty would contribute to opposition from Democrats as well as Republicans and could cost him the primaries or the presidential elections, afterwards. Nevertheless, the promise was never officially recorded and Schmidt stated that the particular "relationship based on trust" between him and President Ford did not require a written record. 
deployed new SS-20 missile systems and improved the Warsaw Pact’s air defense capabilities. ${ }^{99}$

The role of LRTNFs was assessed differently in Europe. Some states saw them as means of “strategically coupling Washington to Europe.”100 They had "an increasing perception that in view of the Soviet nuclear modernization effort, improvements in NATO’s long-range theater nuclear posture were warranted.”101 Others_-including Germany_ argued "that the direction of U.S. SALT policy was not only misguided but actually represented a clear indication of U.S. insensitivity to European security interests.”102 They feared that LRTNF modernization did not bind the United States to Europe. They saw LRTNF as a means to "further decoupling and potential regionalized warfare.” ${ }^{103}$ As a consequence of these two positions, in 1977 "the alliance focused its attention on how the tactical nuclear weapons stationed in Europe could be modernized or supplemented by new systems.”104

The TNF debate stalled after President Carter assumed office in January 1977. The new President of the United States “promoted the strengthening of NATO’s conventional forces and

\footnotetext{
${ }^{99}$ Daalder, 166. Also, sea based Poseidon systems were available but these were considered to be insufficient to balance the Soviet systems.

${ }^{100}$ Spohr Readman, 46.

${ }^{101}$ Ibid. Spohr Readman mentioned the United Kingdom as the main supporter of this thesis. In consequence, the United Kingdom suggested the deployment of cruise missiles in Europe and the exclusion of these weapons in SALT.

${ }^{102}$ Daalder, 166-167. He described that Germany had the political interest on the United States' commitment in Europe.

${ }^{103}$ Spohr Readman, 46. Schmidt described the rationale behind these thought in depth in his memoirs. For him the main question was whether the United States would be willing to risk global nuclear war if Europeans would be attacked or whether there would be an attempt to limit a potential warzone to European terrain even if TNWs would be used. Schmidt, 227-228. Also compare with Brzezinski who stressed in his memoirs that he was initially not convinced about the requirement for European LRTNF. Brzezinski, 307-308. Also compare with Daalder, 167. He described that Germany opposed restrictions on cruise missiles in the SALT negotiations. This is in contradiction with the statement that Germany saw LRTNF modernization as a means to decouple U.S. from European security interests. Still, the fact that the U.S. was willing to negotiate about cruise missiles restrictions was an indication that the United States did not take European concerns sufficiently into consideration.
}

${ }^{104}$ Haftendorn, Security and Détente, 139. 
put forth bold arms limitations and human rights policies vis-à-vis Moscow.” ${ }^{105}$ At the NATO summit in London on May 10-11, 1977, Carter promoted alliance solidarity, tighter cooperation on arms production, and national commitments on defense spending. He proposed to develop a Long Term Defense Plan (LTDP) to match NATO’s requirements for the 1980s and “lobbied for a rapid and successful conclusion of the MBFR talks.”106

\section{Prelude: the neutron bomb affair}

In June 1977, an article in the Washington Post headlined "Killer Bombs Buried in ERDA Budget” initiated a highly polarized public discussion about U.S. plans to field a new type of tactical nuclear weapon. The article mentioned as a distinctive feature of this weapon that it would kill people but would leave matter, like houses, unharmed. ${ }^{107}$ The U.S. Energy Research and Development Administration (ERDA) intended to manufacture new warheads for LANCE missile systems and new nuclear artillery shells. These were named as enhanced radiation warheads (ERWs) and became commonly known as neutron bombs. These weapons would primarily be used against attacking Warsaw Pact tanks without causing the same amount of environmental destruction and collateral damage as older TNWs. ${ }^{108}$

${ }^{105}$ Spohr Readman, 46.

${ }^{106}$ Ibid. For a more detailed view on LTDP, MBFR, and the subsequent implications, see Roger L. L. Facer, Conventional Forces and the NATO Strategy of Flexible Response: Issues and Approaches (Santa Monica: RAND, 1985), 39-48.

${ }^{107}$ Wiegrefe, 181.

${ }^{108}$ Congressional Quarterly Inc, “President Carter 1978,” Congressional Quarterly (April 1979): 45. According to the article, the Energy Research and Development Administration had charge of all nuclear weapons research and production. The term enhanced radiation referred to the fact that these warheads had a relatively small TNT equivalent yield but produced the same level of nuclear radiation as "an older nuclear weapon with [sic] 10 times the explosive power." 
Militarily, these weapons were considered a further development of existing technology and the decision to manufacture them was merely treated as a routine upgrade program. ${ }^{109}$ Politically, nevertheless, opinions were divided on both sides of the Atlantic. In the United States, the question discussed was whether these weapons would increase the deterrence against the Warsaw Pact to attack with conventional forces or whether the neutron bomb would "make nuclear war more thinkable for NATO leaders." ${ }^{110}$ President Carter was at first surprised about the article and the subsequent Congressional debate about the ERW funding. Eventually, he decided to issue a statement in November, but asked Congress to approve the budget in advance. ${ }^{111}$ In an open letter to Congress, President Carter stated that ERWs were in the interest of the U.S. security, but that final decisions awaited for the recommendations from additional Pentagon studies due on August 15, 1977. This paper was interpreted as a presidential approval for the ERW and Congress approved the budget after the letter was published. ${ }^{112}$

In Europe, "the decision by President Carter to ask Congress to provide funding for the production of new enhanced radiation weapons and to call upon the allies to take corresponding decisions concerning the storage and tactical deployment of these weapons systems unleashed a

\footnotetext{
${ }^{109}$ Compare with Wiegrefe 183. Wiegrefe stated that the U.S. Department of Defense treated neutron weapons at the beginning as a routine affair.

${ }^{110}$ President Carter 1978, 45. During the 1977 Congressional debate, U.S. opponents of the ERWs argued also that "there would be pressure to use the weapon in certain circumstances. And once any type of nuclear weapon were used, . . the conflict would escalate to a global nuclear holocaust.” U.S. proponents of the weapon argued that "precisely because the Russians could more easily envision NATO using the weapon to repel an attack, they would be deterred from launching an attack."

${ }^{111}$ Compare with Wiegrefe, 183-185. Wiegrefe mentioned besides being surprised by the discussion, that President Carter had three main reasons to delay an earlier decision. Firstly, he had just stressed his vision of a nuclear weapon free earth in his inauguration speech and was reluctant to increase the nuclear arsenals. Secondly, the ERW program could cause problems for a nuclear test ban treaty and the MBFR negotiations. Thirdly, he would not decide immediately against ERW development because such a decision could be interpreted as personal weakness.

${ }^{112}$ Ibid., 184-185.
} 
fierce and very emotional debate, particularly in the Federal Republic.” ${ }^{113}$ Egon Bahr published an article in the Social Democratic Party’s Vorwärts magazine in July. His article was titled: "Is mankind on the verge of madness?"114 He argued that the ERWs were "a symbol of the perversion of human thinking” because they were leaving buildings and installations intact while extinguishing people’s lives. ${ }^{115}$ This article spurred a strong discussion in the German public as well as inside the governing SPD. ${ }^{116}$ Helmut Schmidt opposed that the United States was pushing for the first time in history a "pure American decision on a nuclear question” on her European allies. $^{117}$

Schmidt assessed the ERWs with reservation. Originally, he had supported the development. ${ }^{118}$ Later, however, he argued that the deployment of these weapons might increase the risk of war in Europe. He also feared a decoupling of American from European security

\footnotetext{
${ }^{113}$ Haftendorn, Security and Détente, 137.

${ }^{114}$ Egon Bahr, "Ist die Menschheit dabei, verrückt zu werden?“ Vorwärts, Juli 21, 1977 quoted in Haftendorn, Security and Détente, 137 and 289.

${ }^{115}$ Haftendorn, Security and Détente, 137. Also compare with Wiegrefe, 185-187.

${ }^{116}$ Though Helmut Schmidt was the head of government, the chairmanship of the SPD remained with former Chancellor Willy Brandt. Within the SPD, there was a long tradition of pacifism and an antinuclear attitude as well as a pending debate on the party's basic values and principles. Though Schmidt was eventually willing to support the ERWs, he needed to take these wings of his own party under consideration to the same degree as his liberal coalition partners. The FDP majority supported ERWs. Compare with Wiegrefe, 187. He observed that the SPD feared more and more the end of the East-West détente that was considered the main reason in foreign policy affairs for establishing the socialdemocratic/liberal coalition in Germany. At the same time, Minister of Foreign Affairs Genscher and other defense experts of the FDP welcomed the new weapon system as an appropriate answer to Soviet tank armament. Also see Soell, Helmut Schmidt: 1969 bis heute, Macht und Verantwortung, 719. Soell describes a dissent in the German Federal Security Council between Chancellor Schmidt and Minister Genscher. He claims that Schmidt regarded the stationing of neutron weapons in Germany as an indicator for American tendencies to further separate a war risk towards Europe. Hence, he refused to link the decision to develop the weapons and the subsequent introduction into NATO. Genscher on the other hand saw this connection as favorable for Germany. He wanted to obtain these weapons. Consensus was reached about an intention to insert these weapons into the MBFR discussions.

${ }^{117}$ Soell, Helmut Schmidt: 1969 bis heute, Macht und Verantwortung, 720.

${ }^{118}$ Compare with Wiegrefe, 184 . In 1970, the NATO Defense Ministers demanded the development of TNWs causing less collateral damage. Schmidt was at that time German Minister of Defense.
} 
interests, should the ERWs be stationed in Germany. Schmidt suggested a compromise. The United States should announce production. At the same time, the willingness for negotiations about a reduction of SS-20 missiles in return for not deploying the ERWs should be stressed by NATO. ${ }^{119}$

Eventually, the German government "developed a discriminating position on the deployment of the new systems.” ${ }^{120}$ Germany underscored her renunciation of nuclear weapons by referring to the signing of the Non-Proliferation Treaty. As a non-nuclear-weapons-state, she refused to decide about the production of ERWs and emphasized that this decision remained the responsibility of the United States. Stationing of these weapons on the territory of Germany would only be possible if other NATO partners shared the burden, "and if within two years the West had not abandoned deployment because appropriate successes had meanwhile be scored in arms control negotiations.”"121 This compromise had been gradually developed through consultations and was in line with a letter President Carter sent to Chancellor Schmidt in November 1977. ${ }^{122}$

Germany declared her willingness to endorse a NATO Council decision acknowledging an American decision on neutron weapons by mid-March 1978. ${ }^{123}$ The German approval required the full internal weight of Chancellor Schmidt to convince the SPD faction of the German Bundestag to support the decision. Similar discussions as in Germany took place in many

\footnotetext{
${ }^{119}$ Spohr Readman, 48-50. She stressed Schmidt's approach to use ERWs primarily as a means for arms control negotiations to reduce the SS-20 systems in the Soviet Union. She described a three step approach. First, the United States should announce production. Then, NATO should declare the willingness to negotiate for two years with the Soviet Union on SS-20 reductions. Should the negotiations fail, then NATO should decide on ERW deployment.

${ }^{120}$ Haftendorn, Security and Détente, 138.

${ }^{121}$ Ibid.

${ }^{122}$ Brzezinski, 303.

${ }^{123}$ Soell, Helmut Schmidt: 1969 bis heute, Macht und Verantwortung, 720. The preconditions were the common support of an included armaments control proposal and a declaration to field these weapons if negotiations about these weapons failed.
} 
European NATO states. ${ }^{124}$ President Carter stated in his memoirs that he "was concerned about the possibility that the weapon would never be deployed, even if it were developed.”125 Consequently, President Carter decided to postpone the production of the ERWs. The "decision was distributed to the NATO council on April, 7” and the NATO meeting was called off. ${ }^{126}$

The analysis of the events that led to the ERW postponement and the conclusions drawn from it differed substantially in the United States. Brzezinski regarded the events as a "major setback in U.S.-European relations” and concluded in his memoirs that “Carter's belated reluctance was matched by Schmidt’s evasive intransigence.” ${ }^{\text {227 }}$ He described how President Carter struggled to decide about the production and deployment of ERWs because "he had campaigned on the nuclear issue" and he quoted President Carter that "he did not wish the world to think of him as an ogre.” 128 The moral struggle of President Carter to decide about the weapons was clearly expressed by Brzezinski’s observation that “I don’t think that I have ever seen the President quite as troubled and pained by any decision item.”129

Brzezinski acknowledged that the U.S. administration perceived the President's general approval to consult with NATO allies about the ERW program in detail at a point in time where Carter was not yet comfortable for it. Eventually, he quoted President Carter's statement from

\footnotetext{
${ }^{124}$ Carter, 226. The Dutch government passed a resolution on March 8, 1978 "stating that production of the weapon was undesirable" and that no agreement to deploy the weapons would be given. Carter observed that there were not many practical options available to field the weapons in Europe. He claimed that "Belgium and the Netherlands had powerful anti-ERW movements; Italy's Communist Party mounted strong opposition; Greece, Turkey, and Portugal were unlikely, given their shaky internal political situations; and Norway and Denmark prohibited deployment of nuclear weapons on their soil. Moreover, as a battlefield weapon ... the ERW made sense only in forward deployment, what made most of these countries irrelevant.” Also see Brzezinski, 303.




March 26, "that his Administration would be stamped forever as the Administration which introduced bombs that kill people but leave buildings intact; and that he would like to find a graceful way out.” ${ }^{130}$ Brzezinski concluded that "leadership means making decisions which the Europeans are not prepared to make” and recommended unsuccessfully to President Carter to decide in favor of the development and deployment of ERWs. ${ }^{131}$

Carter himself described the ERW challenge in his memoirs rather briefly. He observed that "a sharp difference of opinion existed within each NATO country: the military commanders wanted the weapon to be deployed, but the political leaders did not." ${ }^{132}$ He concluded that eventually "[t]he United States was now in an almost absurd position-willing to proceed with the project alone, while insisting fruitlessly on the deployment of neutron weapons by our NATO allies.” ${ }^{133}$ As a result of the internal and external discussions he noted on March 20, 1978 in his diary that he "became more and more convinced that we ought not to deploy the neutron bomb." ${ }^{134}$ He finally concluded that the decision not to produce ERWs was proper and "logical on its own merits and compatible with the desires of most our European allies, but it also conformed to our general policy of restricting nuclear weaponry.”135

Hans Dietrich Genscher remembered specifically the period of time before and after President Carter’s decision. In his memoirs, he supported Brzezinski’s account about the compromise and the planned decision of the NATO Council in spring $1978 .{ }^{136}$ In a meeting in

\footnotetext{
${ }^{130}$ Ibid., 304-305.

${ }^{131}$ Ibid.

${ }^{132}$ Carter, 226.

${ }^{133}$ Ibid.

${ }^{134}$ Ibid., 227.

${ }^{135}$ Ibid., 229.

${ }^{136}$ Genscher, 405. Genscher mentioned a discussion with Warren Christopher who was sent to Europe by Secretary of State Vance after the presidential decision. His mission was to clarify individual details and the rationale of President Carter's reservations. Genscher stressed that Germany was by no
} 
Washington, DC on April 4, 1978, Genscher discussed the way ahead with President Carter, Secretary Vance and National Security Adviser Brzezinski. As a result, an agreed upon declaration was drafted. The decision about the production of ERWs should be moved back and could possibly be used for future armaments control negotiations. Genscher called that "a second class burial” that nevertheless allowed both sides to maintain their face. ${ }^{137}$ Helmut Schmidt mentioned neutron weapons in his memoirs only in passing while discussing general topics like the German-Soviet relations or perceived discontinuities of U.S. foreign policy. ${ }^{138}$

Overall, with respect to the dual-track topic the ERW discussion was mainly shaped by different national interests, a different level of foreign policy related experience, different security related individual philosophies, and different moral views of the respective heads of government. As seen in the discussions about Flexible Response, Germany was very sensitive about any development that might make war in Europe more feasible. At the same time, she was concerned about Alliance cohesion and aware of the U.S. leading role within NATO. Weakening the transatlantic partnership was to be avoided. Germany’s unique approach towards détente and a new

means eager to support the U.S. proposals about ERWs. Rather the government had to overcome substantial resistance within the coalition to eventually endorse the planned NATO decision. This was only done to maintain alliance cohesion. The presidential decision put the Chancellor and himself in a difficult situation.

${ }^{137}$ Genscher, 408. Genscher described how President Carter complained about the lack of support from European NATO members. Carter mentioned a discussion with Austria's Chancellor Kreisky. After Secretary Vance informed President Carter about the fact that Austria was not a NATO member, Carter remarked according to Genscher in an "[sic] ill-natured" manner that "[t]his may be so. In any case, Kreisky is a Social Democrat.” Genscher, 407-408.

${ }^{138}$ Compare with Schmidt, 91 and 160. Opposite to all other considered memoirs and also biographies about Helmut Schmidt, the ERWs are not discussed in a single sub-chapter in Schmidt's book Menschen und Mächte. Part of this fact might be that this book focused on experiences with the U.S., the Soviet Union and China and Schmidt wrote in his preface that "the book is not meant to be an autobiography." Schmidt, 11. Internal discussions about the SPD or the German coalition were not the subject of this book. Still, it is surprising that Schmidt seemed to ignore the topic ERW while he focused in some detail on the dual-track issues. The underlying arguments, respective strategies and initial positions of the United States and Germany on both topics were at least comparable if not similar and most writers connected the ERW issue with the subsequent dual-track discussion. Compare also with Haftendorn, Security and Détente, 137-139, Soell, Helmut Schmidt: 1969 bis heute, Macht und Verantwortung, 712723, and Wiegrefe, 180-204. 
self-consciousness led to an own approach towards ERWs. The proposal to link production with an offer to negotiate about the reduction of the Soviet SS-20 systems at the expense of ERW deployment is the main reason why many scholars consider the neutron weapon issue as a "forerunner of the dual-track decision.” 139

Schmidt was convinced that President Carter did not understand the Soviet thinking about security related questions in full. Also, he attributed to Carter a lack of understanding about European politics and the resulting consequences from U.S. decisions on allied governments. Shortly after the Washington Post article from June 1977 that triggered the ERW discussion was published, Schmidt gave his speech in London in October that many scholars consider to be the initiation of the future NATO dual-track decision. ${ }^{140}$ The ERW discussion developed in parallel to the beginning of the dual-track decision and did not disappear until late spring of 1978 from public perception.

The 1977 speech at the International Institute of Strategic Studies (IISS)

On October 28, 1977 Helmut Schmidt was invited to deliver the Alastair Buchan Memorial Lecture at the International Institute of Strategic Studies (IISS) in London. This speech focused primarily on current world economic problems and included subjects like energy policy and East-West trade. ${ }^{141}$ Only the third part of the speech was devoted to security issues and headlined "SALT, MBFR, neutron weapons, strategic and political necessities." ${ }^{142}$ In this part of

${ }^{139}$ Spohr Readman, 48. Also compare with Haftendorn, Security and Détente, and Wiegrefe.

${ }^{140}$ Friedenssicherung durch Verteidigungsbereitschaft, 193. The ERWs were mentioned in the speech and Schmidt proposed to examine the importance and weight of these weapons with respect to armaments control efforts.

${ }^{141}$ Schmidt, 232.

${ }^{142}$ Friedenssicherung durch Verteidigungsberitschaft, 192-194. Helmut Schmidt gave the speech in English. For this monograph, the officially archived German version is being used, titled „Politische und wirtschaftliche Aspekte der westlichen Sicherheit“ from Bulletin der Bundesregierung, (8. November 1977), S. 1013ff., quoted in Friedenssicherung durch Verteidigungsbereitschaft. This version contains only the relevant parts of the speech about security policy. 
the speech, Schmidt stressed the importance of the maintenance of a political-military balance between East and West. He considered it a precondition for security to the same degree as the continuation of a fruitful détente. He stated that the efforts of the United States and the Soviet Union to limit the SNWs in the conduct of the SALT process mutually excluded the possible use of these potentials.

Consequently, the importance of disparities concerning TNWs and conventional weapons would rise in Europe. He concluded that limitations of strategic armaments between the two global powers would diminish European security requirements if one would not succeed in removing existing disparities in Europe in parallel to SALT ${ }^{143}$ He continued that Europe did not articulate clearly enough the requirement for parity on the strategic level to the same degree as on tactical and conventional level at the beginning of the SALT process. The connection between SALT and MBFR needed to be recognized and practical conclusions needed to be drawn. He concluded that two general possibilities were available to achieve a conventional balance between NATO and the Warsaw Pact. The first option would lead to massive armament of the western alliance. The second option— that Schmidt preferred—would be a commonly agreed reduction on both sides. $^{144}$

Everything Schmidt mentioned was in line with previous speeches and statements he had given before on security related issues. ${ }^{145}$ He had mentioned the grey-zone of what he called eurostrategic weapons, for example, to President Carter at the NATO summit in May 1977. Brzezinski’s assessment of Schmidt's rationale largely confirmed Schmidt's views. Brzezinski referred to the SS-20 deployments and the Soviet Backfire bombers, stating "[b]oth these new

${ }^{143}$ Soell, Helmut Schmidt: 1969 bis heute, Macht und Verantwortung, 709-710.

${ }^{144}$ Friedensicherung durch Verteidigungsbereitschaft, 193.

${ }^{145}$ Schmidt mentioned in his memoirs that the first time the issue was officially discussed occurred at a visit in the Soviet Union in October 1974 after Schmidt became German Chancellor. Schmidt, 66. 
weapons systems were capable of hitting targets anywhere in Europe, without any effective Europe-based nuclear counter. The Europeans feared that the Soviets would now be able to exert a greater degree of political pressure than ever before, while at the same time strategic parity and our efforts to achieve strategic arms limitation would limit American willingness to respond to Soviet attack or provocation.”146

Leopoldo Nuti concluded that "[t]he IISS speech was the climax of a personal campaign that Schmidt had been waging to persuade the US to include Soviet TNF in the new SALT, beginning with a personal discussion with President Gerald Ford in 1975 and continuing with a forceful presentation of the issue of conventional parity at the NATO council held in May 1977.”147 Schmidt was frustrated with the United States because his position was not sufficiently taken into account. Hence, he went public at the IISS lecture. ${ }^{148}$ Brzezinski supported the statement about the lack of attention Schmidt's arguments received in Washington. He reflected on divergent U.S. and German perceptions about the Soviet Union and détente in July 1977. According to Brzezinski, Schmidt suggested being more responsive to Brezhnev and proposed “direct contacts between Carter and the Soviet leader, with himself [Schmidt] as the intermediary." ${ }^{149}$ This proposal was not taken up by the President. ${ }^{150}$

Hartmut Soell concluded that the speech would not have drawn a lot of attention in Washington, had there not been a subsequent question and answer opportunity after the speech on

\footnotetext{
${ }^{146}$ Brzezinski, 307
}

${ }^{147}$ Leopoldo Nuti, “The origins of the 1979 dual track decision - a survey” in Leopoldo Nuti, ed., The Crisis of Détente in Europe: From Helsinki to Gorbachev, 1975-1985 (London and New York: Routledge, 2008), 63.

${ }^{148}$ Ibid., 63.

${ }^{149}$ Brzezinski, 307.

${ }^{150}$ Ibid. Brzezinski continued his description with the supposition that Schmidt increased his personal critique on President Carter afterwards and that Schmidt "suspected that I [Brzezinski] talked Carter out of the idea of using Schmidt as an intermediary . ..., and, as I [Brzezinski] have noted elsewhere, he was not entirely wrong." 
the occasion of a common dinner. According to Soell, a close co-worker of former Secretary of State Kissinger was present and raised specific questions about the SS-20 subject. Schmidt replied by explaining the "grey-zone” problem in detail. This led eventually to the perception in Washington that the speech could be interpreted to be "a kind of European protest against the President.”151 The U.S. administration concluded that Schmidt’s critique required action.

In his memoirs, Schmidt supported Soell's claims. Schmidt wrote that the international audience particularly at the dinner recognized that "the German Chancellor set directions, which differed clearly from those of the new American President." ${ }^{152}$ Eventually, the speech and its emphasis on imbalances in non-strategic weapons was linked particularly to the SS-20 deployment of the Soviet Union and considered to be "the beginning of a historic reversal of the momentum of the global balance of forces, as well as the opening shot of the political battle over the euromissiles." 153 Schmidt claimed in his memoirs that London the speech "has later now and then been called the actual hour of birth of the so called dual-track decision.”" ${ }^{54}$ Still, he stressed that his intention was not to promote a western counter-armament. His main purpose was to integrate eurostrategic nuclear weapons and conventional forces into the aspired armaments limitations of SALT II. ${ }^{155}$ The speech was nevertheless perceived differently. The restoration of parity at the non-strategic level by including TNWs and conventional forces in arms control measures was the main proposal. Should this fail, "then the next available alternative would be

\footnotetext{
${ }^{151}$ Soell, Helmut Schmidt: 1969 bis heute, Macht und Verantwortung, 716-717.

${ }^{152}$ Schmidt, 233.

${ }^{153}$ Herf, 54.

${ }^{154}$ Schmidt, 232.

${ }^{155}$ Ibid. Schmidt stressed that the text of the speech was unambiguous in that respect.
} 
some form of rearmament." ${ }^{156}$ Nuti argued "[w]hile not openly advocated at the IISS speech, this second track was the logical conclusion.”157

\section{Consequences of the speech and implementation of NATO’s High Level Group (HLG)}

A few weeks prior to Helmut Schmidt's speech, the British Minister of Defence

Frederick Mulley had “emphasized the need for new theater nuclear forces” to his U.S.

counterpart. ${ }^{158}$ In a letter Mulley specifically mentioned the requirement for NATO intermediate range missiles to counter the imbalance caused by Soviet systems in that spectrum. Nuti argued that for the United States this proposal "suggested a possible solution to the problem—albeit one that Schmidt was not yet ready to consider-which drew upon the conclusions of the previous strategic debates inside the alliance. Both episodes accelerated the impulse to renew the discussion about modernization of NATO’s TNF.”159

The U.S. answer to that problem was the establishment of a NATO High Level Group (HLG) to discuss theater nuclear forces issues and provide recommendations to the NATO Council. ${ }^{160}$ The HLG was formally implemented by NATO’s NPG in October 1977. This approach was in line with nine pre-existing NATO expert groups discussing NATO’s Long Term Defense Plan on conventional forces. The HLG would be composed of "senior representatives from the capitals” to ensure that the member states leadership had a direct influence on the discussions. This was the first time that the U.S. administration was willing to discuss modernization issues about nuclear weapons with her allies. Before, only deployment questions

\footnotetext{
${ }^{156}$ Nuti, 63.

${ }^{157}$ Ibid.

${ }^{158}$ Ibid.

${ }^{159}$ Ibid.

${ }^{160}$ Spohr Readman, 51. The HLG derived from NATO’s Long Term Defense Plan Task Force 10
} and was converted to the status of HLG. 
had been common topics in the NPG or the Nuclear Defense Affairs Committee. ${ }^{161}$ For the first time in history, NATO as a whole took a procurement decision. ${ }^{162}$ The HLG was led by the United States. U.S. Assistant Secretary of Defense David McGiffert became the group’s chairman. This was also a new approach. Normally, a member of NATO’s International Staff would have been chosen to lead an expert group within the Alliance. Eleven NATO members participated in the HLG. ${ }^{163}$ Later, a Special Group (SG) also under U.S. chairmanship was established to discuss the arms control package. ${ }^{164}$

Kristina Spohr Readman analyzed the HLG process in depth and came to the conclusion that "U.S. political and military elites and the president himself never managed nor truly desired to lead the intra-allied negotiations over LRTNF. Instead, a rather unenthusiastic U.S. administration had to be urged by the Europeans to respond firmly to Soviet nuclear politics.”165 After the HLG was formally established on October 11, 1977, the group started discussing nuclear related issues. One of the advantages of this particular forum was that the groups mandate

${ }^{161}$ Compare with Nuti, 63-64. The NDAC included all NATO countries and was abolished in 1974 as a consequence of the Portuguese Revolution in 1974. More details can be found on the NATO's official website under NATO - Topic, “The Nuclear Planning Group,” NATO, http://www.nato.int/cps/en/natolive/topics_50069.htm (accessed December 23, 2013). It should also be noted that the NPG, as the senior NATO body on nuclear matters, makes decisions on the level of NATO Defense Ministers. The members of this group are not necessarily nuclear experts. The establishment of expert groups to prepare and support NATO senior body decisions is a standard procedure within NATO's administration.

\footnotetext{
${ }^{162}$ Spohr Readman, 40.

${ }^{163}$ Nuti, 63.

${ }^{164}$ Spohr Readman, 40.

${ }^{165}$ Ibid., 43. Spohr Readman challenged with her thesis various scholars like Raymond Garthoff, to the same degree as Leopoldo Nuti or Helga Haftendorn. She was able to access various formerly classified documents though she acknowledged that many important documents have not been declassified, yet. Spohr Readman focused specifically on the role of smaller NATO members and their influence on the HLG discussions and recommendations. She found amongst other things that the United Kingdom, Norway and Germany had a greater influence then earlier works proposed. For this monograph, the distinct proposals and recommendations of the HLG and SG are taken under consideration because her work is based on more and comprehensive sources than previous literature. The specific national influence within distinct HLG and SG meetings is not considered to be of utmost importance because this monograph focuses on the
} memoirs of former political leaders. 
and composition did not require approved national positions. ${ }^{166}$ In parallel to the politically driven ERW discussion in the capitals, the group worked on practical proposals for nuclear modernization and the composition of NATO’s nuclear arsenal. The HLG "became the arena for major political (pre-) decisions on future TNF production and deployments.”167

At the beginning of the groups work, Europeans were encouraged to present their own views, given the lack of a clear U.S. position on how to proceed. The British representative suggested the need for improving long-range theater nuclear forces to overcome a gap between short-range tactical nuclear weapons and the strategic arsenals. Germany supported this position at the first HLG meeting on December 8-9, 1977. The U.S. chairman developed four possible TNF options. These were discussed in detail at the next HLG meeting in Los Alamos in February 1978. Eventually, the United Kingdom, Norway and Germany led the discussion towards a perceived agreement to emphasize increased targeting of deep support lines to a Warsaw Pact offensive. The consequence would be a strengthening of the LRTNFs. ${ }^{168}$ Spohr Readman described that the draft report of the Los Alamos meeting provided by the U.S. delegation did not reflect the consensus in full. According to her, the U.S. version of the report even increased the importance of short range TNWs at the expense of LRTNFs. This was

\footnotetext{
${ }^{166}$ The HLG did not have the authority to decide about nuclear policy. This remained with the NPG. The purpose of establishing the HLG was amongst other things to get expert based recommendations, independently from political, national restrictions.

${ }^{167}$ Nuti, 64. Also compare with Spohr Readman, 51.

${ }^{168}$ Compare with Spohr Readman, 52-54. The four options were described as "continuation of the emphasis in the existing posture (option I); increased emphasis on the engaged battle area and its immediate support (option II); increased emphasis on targeting deep support lines to a Warsaw Pact offensive (option III); and balanced emphasis on engaged battle area and deep support (option IV).” After lengthy and controversial discussions, the preference lay with option III. Militarily, this option would enhance NATOs responsiveness including the possibility to counter Soviet attacks without excluding Soviet terrain and without the requirement to use SNWs. Politically, this option was considered more feasible than option IV because it provided deterrence against SS-20 systems but stressed the defensive character of the proposal. Also compare with Nuti, 64. He described the results of the HLG discussion as an "upward evolutionary adjustment of the Alliance's TNF" on the rationale of "anticipating the results of the Carter administration's [sic] decisionmaking process.”
} 
closer to option II-increased emphasis on the engaged battle area and its immediate support. This option was originally favored by the U.S. delegation. In a subsequent HLG meeting on March 17, 1978, no consensus could be reached about the proposals from Los Alamos. A report to the NATO Ministers of Defense was due in April 1978. President Carter decided to postpone the ERWs in late March. ERWs fell exactly into the weapons category the U.S. HLG delegation was promoting. Spohr Readman concluded that "[n]ot only did the U.S. administration lack harmony, it could no longer claim to be controlling the HLG process.” ${ }^{169}$ Ensuring a credible defense and deterrence posture for NATO became primarily a political necessity after progress on expert level was no longer sufficient. ${ }^{170}$ The U.S. had not decided on her position of how to proceed with LRTNFs. After the ERWs discussion, nevertheless, the U.S administration was aware that LRTNFs could become an even bigger political problem, should the European positions not be taken sufficiently under consideration.

Various interconnected subjects shaped the political discussion within NATO at this time. These were NATO’s debate about the modernization of TNF, the SALT II debate, and a “growing perception of the need to strengthen US leadership after the ERW debacle.”171 Eventually, NATO Defense Ministers agreed at the Fredrikshaven NPG meeting on April 19, 1978 on the general requirement to upgrade TNF systems in Europe. ${ }^{172}$ Still, the U.S. political commitment towards LRTNWs was challenged by her European partners. The United States

\footnotetext{
${ }^{169}$ Spohr Readman, 56.

${ }^{170}$ Ibid., 57. She described also that the U.S. delegation refused to make amendments as requested by the European members of the HLG to the Los Alamos report. They even considered providing a chairman's report instead to the NPG that was planned on April 18-19, 1978 in Frederikshaven.

${ }^{171}$ Nuti, 65. Nuti concluded that "the work of the HLG seemed one of the best possible tools to reinvigorate NATO and restore some optimism to the transatlantic relationship” after the alliances trust in the United States was seriously shaken by the ERW controversy.

${ }^{172}$ Also compare with Friedensicherung durch Verteidigungsbereitschaft, 180. At the NPG meeting in April 1978, NATO at ministerial level endorsed the requirement to modernize European based nuclear systems.
} 
remained on a rather general level when discussing modernization issues of nuclear weapons. At the NATO summit in Washington on May 30-31, 1978, President Carter stressed the need for a general replacement and modernization of nuclear weapons and declared the willingness of the United States to discuss the SS-20 issue. But he was far from proposing concrete upgrade programs for LRTNWs. By mid-1978, the Alliance at least generally agreed on the requirement for LRTNW modernization, though with different motives and determination. ${ }^{173}$ The HLG would henceforth discuss about how to modernize nuclear weapon systems. The United States tried to regain the leadership role within this forum.

\section{The U.S. political rationale}

In the summer of 1978, the political situation in the United States with respect to nuclear modernization was as complicated as in Europe. As late as April 1978, a discussion about LRTNWs modernization was considered to be unneeded because the U.S. SNWs were viewed to be sufficient to counter the Soviet SS-20 arsenal. This posture changed for various reasons after the discussion within the alliance had started. First, the United States had a general interest to improve transatlantic relations. Specifically after the ERWs issue, the Carter administration was eager to demonstrate competence and the ability to act to critics on both side of the Atlantic. Brzezinski described the effects of the ERW decision to "affect the creditability of his [the President's] leadership and will sow dissension within the alliance and negative Congressional reactions.”174

\footnotetext{
${ }^{173}$ Spohr Readman, 58. She also identified inner-European differences about the rationale for upgrading LRTNFs. The United Kingdom promoted LRTNFs modernization mainly to overcome NATO's general structural weakness in that area, independent from Soviet SS-20 threats. West Germany, on the other hand promoted NATO LRTNF systems to balance the distinct threat caused by SS-20 missiles.

${ }^{174}$ Brzezinski, 306.
} 
Brzezinski concluded that some initiatives would be required to enhance the standing of President Carter. ${ }^{175}$ More importantly, President Carter needed European support for his main project concerning nuclear weapons - the SALT II treaty. Besides the peace process in the Middle East, the success at SALT II can be considered the most important foreign policy related subject for Jimmy Carter in his presidency. In his memoirs, Carter dedicated an entire chapter on the SALT issue. ${ }^{176}$ He described that he had pledged in his inaugural address "to work toward the ultimate goal of eliminating nuclear weapons from the earth." ${ }^{177}$ He concluded that "forging an effective arms control policy” was complex. Though the basic goals were clear, "we had to wrestle with technical, political, economic, and moral questions of enormous difficulty." ${ }^{178} \mathrm{He}$ stressed that "[o]ur best hope lay in the Strategic Arms Limitation Talks, known as SALT. If these resulted in an arms control agreement, it would not only benefit the United States and the Soviet Union, but might serve as a model for other nations.” ${ }^{179}$

${ }^{175}$ Compare with Wiegrefe, 253.

${ }^{176}$ Carter, 212-265. A detailed description on Carter's thoughts and motives about SALT would exceed the frame of this monograph. Carter described in general the obstacles he saw to achieve an agreement with the Soviet Union. He indentified mutual distrust, the influence of military-industrial complexes in both countries, different political systems, difficulties in comparing the respective SNW arsenals, the speed of technology developments, and other factors like the expected linkage of Soviet behavior in other political areas to progress on arms control, the idea of "outspending" the Soviet Union, and the assumption that the Soviet Union had violated treaties before and would continue to do so. Carter stressed in detail the difficulties for Senate ratification after a treaty is signed. He identified partisan issues as well as the tendency to link approval to other, non-SALT related decisions to be major obstacles. Also compare with Brzezinski, 316-353. He described the SALT process in detail to the same degree as Jimmy Carter, though with a different focus. The level of detail in both memoirs indicated the importance of SALT specifically when compared with the few remarks President Carter and his National Security Adviser spent on NATO's dual-track decision, respectively.

\footnotetext{
${ }^{177}$ Ibid., 215.

${ }^{178}$ Ibid.

${ }^{179}$ Carter, 213.
} 
Carter was aware that once a treaty was negotiated, the required ratification by the U.S. Senate would be greatly influenced by European allied support towards the agreement. ${ }^{180}$ According to Klaus Wiegrefe this understanding led to a change of attitude within the U.S. administration. Starting in summer 1978, the deployment of LRTNWs should be supported to avoid jeopardizing the progress of the SALT treaty. ${ }^{181}$ To avoid a political fiasco as happened only few months before with the ERWs, Brzezinski wanted the decision making process to be steered by the National Security Council.

On June 22, 1978, President Carter signed Presidential Review Memorandum (PRM) 38. It tasked an intra-agency study about the military and political aspects of "[p]ossible increased long-range theater nuclear force capabilities in Europe for strategic strikes on the Soviet Union” and “[p]ossible inclusion in future arms control negotiations of long-range theater nuclear systems.” ${ }^{182}$ The summary of the intra-agency results provided mainly two different points of view concerning a possible TNF modernization and related arms control proposals. The Pentagon argued that the Soviet Union pursued a TNWs approach that would improve her ability to conduct a limited nuclear war in Europe. This might lead the Soviets to the assumption that the United States and her Allies could be politically decoupled. Hence, Secretary of Defense Brown supported the deployment of nuclear weapons in Europe that could reach Soviet territory.

\footnotetext{
${ }^{180}$ Wiegrefe, 253-254. Wiegrefe stressed that a Congressional dismissal would have severe domestic and foreign policy consequences for President Carter. Specifically Chancellor Schmidt's continuing critique about U.S. negotiations in conjunction with the grey zone topic was considered to be supportive for Carter's Congressional opponents. Wiegrefe referred to a report from a German member of parliament who stated after a visit in the United States that "the European discussion about grey zone weapons is frequently understood in the USA as a discussion against the SALT agreement."

${ }^{181}$ Ibid., 254. Wiegrefe identified Brzezinski as the driver for this policy change and quoted him as follows: "Personally, I have never been convinced that we needed TNF for military reasons." He stated that Brzezinski was reluctantly persuaded that these weapons were needed for European support of SALT. Also see Brzezinski, 308-309.In his memoirs, Brzezinski stated, he "was doubtful that a military response based on Europe was needed, but I was convinced by my staff ... of the political necessity to deploy Europeanbased nuclear counter.”

${ }^{182}$ National Security Council, Presidential Review Memorandum/NSC - 38, (June 22, 1978), 1. http://www.fas.org/irp/offdocs/prm/prm38.pdf (accessed December 26, 2013).
} 
In addition to that, the United States generally feared a future Soviet first strike capability. Cruise missiles on European soil could help countering that threat because of their accuracy. ${ }^{183}$ The State Department on the other hand concluded that the latest European reservations had to be seen in a greater context. They argued that Watergate, the Vietnam War and perceived inconsistencies in President Carter’s decision making caused a loss of political trust in the United State's leadership. Deploying new nuclear weapons in Europe might lead to the European perception that the United States were planning for a limited nuclear war capability on European soil, themselves. ${ }^{184}$ Consequently, the State Department voted for a political solution. The Soviet SS-20 systems should be included and the Europeans should be more involved in arms control talks. ${ }^{185}$ As a compromise of both positions the "integrated strategy" of nuclear arms modernization in combination with arms control offers was established. ${ }^{186}$

As a result of the PRM 38 study, in the following months the U.S. administration started to focus on LRTNW systems. The U.S. position eventually converged with her European allies. ${ }^{187}$ The U.S. promoted an integrated strategy by end of August 1978. This approach excluded pure arms control solutions as well as pure deployment decisions. From now on, deployment decisions_-including LRTNWs—-would be combined with arm control efforts. This was adopted to reassure the Federal Republic of Germany, specifically, and provide the

\footnotetext{
${ }^{183}$ Wiegrefe, 255. Cruise missiles were one of the already discussed options for NATO LRTNF. Originally, the possible Soviet first strike capability would have been avoided, had the Soviets agreed to Carter's deep cut SALT proposals in 1977. The Soviet Union refused to negotiate further than generally agreed during the Vladivostok talks between President Ford and Brezhnev on November 23-24, 1974. Compare with Carter, 217-219.

${ }^{184}$ Wiegrefe, 255. This argument was in so far valid as it had already been used by European politicians on the ERW issue.

${ }^{185}$ Ibid., 256. Wiegrefe also mentioned the plan to assign additional strategic forces to NATO.

${ }^{186}$ Ibid. The U.S. rationale was that the Kremlin would only seriously negotiate if the alliance had something "to offer." Also, the European partners required an arms control element for domestic reasons. Also compare with Nuti, 65 and Spohr Readman 61.

${ }^{187}$ Spohr Readman, 60. She refers to a Special Coordinating Committee Meeting about PRM 38 in August 1978 and an NSC memo to the Vice President from August 22, 1978.
} 
politically required arms control “cover” enabling Germany to support new weapon

deployments. ${ }^{188}$ For Schmidt, arms control efforts were never meant to cover for deployment programs. He was convinced that arms limitations were the best options and saw deployment decisions as the "bait" to agree on eventual weapon reductions. ${ }^{189}$

Despite the misunderstanding about motivations and political thinking behind these proposals, European and U.S. approaches were largely in agreement by mid-1978, especially as the United States had shifted towards LRTNWs modernization. This clear statement was required to have an unambiguous and approved U.S. position for NATO's political processes as well as for U.S. experts in various working groups. Nevertheless, this meant by no means that NATO's military experts and political leaders were in line with their specific recommendations, be it on NATO level or in the member states. Still, after the U.S. position had been cleared, the HLG could go ahead with its task.

\section{HLG proposals of 1978, the roots of the dual-track decision}

The HLG continued its work at a meeting from October 16-17, 1978. Prior to the meeting, the German and United Kingdom delegations harmonized their views to present a European position. This would "help the old continent to stand up to Washington” should interests be different. ${ }^{190}$ German HLG members moved even closer to the British attitude that LRTNW modernization should primarily be aimed at closing the existing military gap between

\footnotetext{
${ }^{188}$ Ibid., 61. According to her, the U.S. was merely interested in deploying LRTNF, should this be required as a result of the ongoing NATO negotiations. In that case, Germany's support could only be expected if certain arms control emphasis would be included to convince the public. An alternative would still be to modernize the existing TNW systems without shifting to longer range weapons, as originally supported by the U.S. in the HLG talks from spring 1978. Also compare with Nuti, 65. He described that even though the PRM 38 task linked deployment and arms control, "in the following months the Carter administration openly focused only on the rearmament proposals of the HLG." See also Wiegrefe, 255-256.

${ }^{189}$ Schmidt, 229-230, and 232.

${ }^{190}$ Spohr Readman, 63.
} 
TNWs and SNWs. ${ }^{191}$ The German delegation stressed, however, that Germany would not support a solution in which new weapons would only be deployed in Germany. In addition to that, Germany would not operate LRTNWs under a dual-key system because there could not be a "German finger on the trigger." 192 As a result, the HLG concluded that an LRTNW equivalent to the Soviet systems was not required. Instead 300-500 new NATO weapons were envisioned, widespread national participation was required, and "that some capability had to be deployed, even if arms limitations were to be considered.”193

At the following NPG meeting on October 20, 1978, the U.S. delegation requested concrete European proposals on LRTNW types, deployment sites, financing, and arms control relations. Secretary of Defense Harold Brown made explicitly clear that the United States would not force new LRTNWs on her allies. If Europeans voted against new systems, none would be deployed. Brown argued that a public debate like that which happened six months before on the ERWs should be avoided. ${ }^{194}$ Germany’s Defense Minister Hans Apel stressed that

${ }^{191}$ Ibid. Spohr Readman described that the German Defense experts moved even closer to the British attitude that LRTNF modernization should primarily be aimed at closing a military gap between TNWs and SNWs. By that, Flexible Response would be strengthened. She observed the German position that "LRTNF should not be dispensable arms control bargain chips" and that "progress in identifying weapons requirements ... was likely to stall if the HLG attempted . . . to define the exact relationship with arms control.” This approach was definitely not fully harmonized with the political leadership in Germany.

${ }^{192}$ The dual key approach referred to the solution on TNWs that Germany owned delivery assets but the United States owned the warheads and the codes to launch TNWs. Hence Germany could not use nuclear weapons by herself. The United States could not use German delivery assets without consent. For LRTNF, this approach was mainly declined because Germany feared to upset the Soviet Union's leadership, should Germany be perceived to be able to fire nuclear weapons on Soviet territory. Compare with Spohr Readman, 64 and Haftendorn, Security and Détente, 143. Haftendorn stressed that the decision to abstain from a dual-key approach "represented a modification of the nuclear cooperation practiced within the alliance since the 1960s."

${ }^{193}$ Spohr Readman, 65. Also see Daalder, 194. Daalder stressed that these numbers were politically feasible. He also explained that the Pentagon and NATO military recommended between 1,500 and 2,000 warheads. For a more detailed analysis about the military requirements, see Daalder, 211-213.

${ }^{194}$ Ibid., 64. The decision about specific NATO LRTNF systems was not made at that time. Still, ground launched cruise missiles (GLCM), sea launched cruise missiles (SLCM), air launched cruise missiles (ALCM), Pershing II ground launched missiles, Longbow Missiles, and F-111 aircraft were under consideration to be suitable systems. Also compare with Nuti, 65 . He referred to rearmament options in the fall of 1978 as defined by the U.S. administration. These were "[sic] 1) sea or ground-based cruise missiles 
recommendations of NATO's military experts “must not prejudge ministers' decisions and that the ultimate political decisions remained firmly with the capitals.” ${ }^{\text {995 }}$ This statement must be seen in light of the HLG recommendations, indicating that a comprehensive German governmental position had not yet been agreed upon. The German HLG representatives supported a view close to the British delegation and in line with Foreign Minister Genscher's statements on LRTNWs. But Genscher and Minister of Defense Apel did not fully agree with each other or with Chancellor Schmidt. ${ }^{196}$

The HLG continued its consensus based work towards concrete proposals that would lead to a NATO decision by end of 1979. Based on previous HLG discussions, the group proposed a moderate modernization of NATO's assets. The aim was to provide credible capacity to retaliate appropriately against the Soviet SS-20 systems. ${ }^{197}$ Eventually, a mix of cruise and ballistic missiles were considered the best option. The development of new medium-range ballistic missiles was discussed but eventually dismissed. Instead, a plan was developed to replace a number of existing Pershing I short range missiles in Germany with a further development. The Pershing II XR (extended range) version offered a range of 1,800 km and a possible further extension to 2,200 km. Though this weapon could not reach the SS-20 launch sites inside the Soviet Union, it could reach Soviet soil and had the advantage that the development had already started. Developing an entirely new missile would have cost too much time. The main disadvantage of the Pershing I replacement solution was that these weapons were only deployed

(SLCMs or GLCMs); 2) intermediate range ballistic missiles with a range of 1,000 to 1,500 miles (Pershing II and Longbow); and 3) the creation of new bases for the US FB 111H aircraft.”

${ }^{195}$ Ibid., 66.
${ }^{196}$ Ibid., 67.

${ }^{197}$ Wiegrefe, 257. Wiegrefe also stressed that the HLG did not intend deploying sufficient TNF to balance the Soviet assets in full. Less cruise missiles systems were assessed to be a better option with respect to the ongoing SALT negotiations. Cruise missiles had already been subject to intense discussions in the SALT process before. For a more detailed discussion on European expectations with respect to cruise missiles, compare with Daalder, 166-168. 
in Germany so far because of their limited range. Pershing II XR systems would face the same problems because of their range limitations. ${ }^{198}$ This contradicted German political demands to not be the only country where new LRTNWs would be stationed. ${ }^{199}$ Also, the relatively quick preparation time of the Pershing II and the short flight time to reach targets could be interpreted by the Soviets as the development of a European based first strike capability. ${ }^{200}$ Still, the German HLG delegation did not object to the proposal. Concerning the overall amount of nuclear warheads to be deployed, the HLG agreed to propose a number of 200 to $600 .^{201}$ The HLG concluded that a common report could be sent to the Defense Ministers including a recommendation to decide formally by end of 1979.

By end of 1978, the defense experts of the HLG had been able to reach a consensus on what to propose to the political leaders. This agreement prefigured the numbers and types of LRTNW systems that NATO eventually decided to deploy in December 1979. Since the HLG members were relatively free to discuss matters and the recommendations had not been fully harmonized within the NATO member states. The HLG was only mandated to propose future LRTNW modernization and deployment questions. More importantly, the extent of possible arms control initiatives in conjunction with the LRTNF modernization proposals was not mandated to the HLG. These decisions remained with the political leadership and were not harmonized within the member states, yet. These facts caused subsequently additional discussions in the member states and within higher NATO bodies that had to approve the recommendations of the HLG.

\footnotetext{
${ }^{198}$ Wiegrefe, 258. Also compare with Haftendorn, Sicherheit und Stabilität, 112. Haftendorn described that five weapon systems were generally under consideration (GLCMs, SLCMs, ALCMs in conjunction with FB-111H aircraft, and Longbow missiles). She stated that a HLG majority in favor of Pershing II and GLCMs was achieved between November 1978 and February 1979.

${ }^{199}$ Haftendorn, Sicherheit und Stabilität, 109.

${ }^{200}$ Ibid.,112 and Wiegrefe, 258.

${ }^{201}$ Wiegrefe, 258. The U.S. initial proposal covered a number of 100 to 2,500 nuclear warheads. Military experts supported numbers on the higher limit whereas mainly European members of the HLG concluded that not less than 100 and not more than 600 warheads would be required.
} 


\section{$\underline{\text { Political discussions in NATO until the end } 1978}$}

Achieving a political consensus between the capitals of NATO member states on LRTNW modernization was far more difficult than on expert level within the HLG. As German Minister of Defense Apel had pointed out at the NPG in October, eventually national parliaments had to approve governmental decisions in every single member state. Public opinion played a crucial role on nuclear related issues, as the ERW discussion already demonstrated. Also, national policies in member states differed substantially. Norway and Denmark for example refused to deploy nuclear weapons on their territory out of principle. Internal discussions in the Netherlands and Belgium indicated that an agreement for deployment in these countries would be difficult. ${ }^{202}$ Germany insisted on not being the only deployment country. The range of the proposed LRTNWs required a deployment close to Iron Curtain to reach Soviet territory. In addition to that, the role of arms control measures in conjunction with a possible deployment decision was not commonly agreed upon.

The United States continued focusing her arms control efforts on SNWs and SALT II. Including LRTNWs in arms control talks was viewed as an unavoidable necessity in inner European discussions. Helmut Schmidt promoted the arms control approach as the key element. For him, deployment decisions served primarily the purpose of enabling appropriate arms control measures. He wanted the LRTNWs to be included in SALT II. The British generally supported the modernization of LRTNWs to enhance NATO’s deterrence posture. They promoted separate strands of rearmament and arms control. ${ }^{203}$ France remained absent from internal NATO discussions. ${ }^{204}$ Overall, ten months after the HLG Los Alamos discussions, NATO member states

\footnotetext{
${ }^{202}$ For a more detailed description of Danish, Dutch and Belgian positions prior to the dual-track decision, see Daalder, 176, 184-185, 197-198, and 200-204.

${ }^{203}$ Daalder, 183.

${ }^{204}$ Generally, France at that time was hesitant discussing the "grey zone" issue because she did not want the French nuclear weapons to be included in U.S. - Soviet negotiations. Nevertheless, at the margins
} 
were required to develop national positions on LRTNW deployment and arms control measures.

At the North Atlantic Council (NAC) meeting in November 1978, SALT, the "grey area"

problem, and NATO LRTNWs were addressed together for the first time. ${ }^{205}$

\section{Guadeloupe}

In October 1978, National Security Adviser Brzezinski was sent on a trip to London, Paris, and Bonn. His primary mission was to consult on TNF issues with the British Prime Minister, the French President and the German Chancellor. Brzezinski wrote that “[m]y trip in October 1978 was particularly important because the conversations I had with Helmut Schmidt, James Callaghan, and Giscard d'Estaing foreshadowed some of the difficulties we would have on the question of theater nuclear forces.”206 He concluded that the gray area issue would cause problems in alliance relationships in the 1980s. He found that "Europeans are worried; yet they are not quite sure what ought to be done about it and are likely to shrink away from any concrete solution."207

As a result of the conversation he had with Helmut Schmidt, the advantage of informal strategic talks between the four heads of government was identified. Brzezinski supported “a forum where the leaders of the four countries most directly engaged in security problems could

of France-German consultations in September 1978, Schmidt and Giscard d'Estaing discussed the threat of Soviet SS 20 and Backfire bombers. Schmidt argued towards Giscard that the United States had only few comparable means_-some cruise missiles were already available-deployed in Europe to balance SS-20 systems. These cruise missiles might even be limited as the result of SALT II. Schmidt expressed his concern that the Soviet Union might gain a military superiority in less than ten years. In combination with the Soviet superiority in conventional arms this imbalance could spoil the credibility of SNW use. According to Soell, this led Giscard to the conclusion that "in the long run, France could not remain completely outside NATO’s defense.” Soell, Helmut Schmidt: 1969 bis heute, Macht und Verantwortung, 728.

\footnotetext{
${ }^{205}$ Spohr Readman, 68.

${ }^{206}$ Brzezinski, 294.

${ }^{207}$ Ibid.
} 
meet and discuss frankly, openly, and flexibly matters of common concern." ${ }^{208}$ After approval from President Carter, who noted at the margins of a paper that the possibility of such a meeting had already been discussed at the Economic Summit in Bonn, the meeting was planned. President Giscard d'Estaing's invitation to meet in Guadeloupe went out for January 5-6, 1979. ${ }^{209}$ The four heads of government met in a relaxed atmosphere at the Hamak Hotel in St. François. The morning talks of January 5, 1979 were conducted only by the principals. In the afternoon and the subsequent day, each delegation consisted of two members. Official notes and decisions were not taken. The meeting served the purpose of exchanging opinions and was not meant to replace an established forum. ${ }^{210}$

For Carter, the most important talks concerned nuclear weapons and future relationships with the Soviet Union. He reflected on general concerns that the Soviet Union's isolation “might cause it to discount the restraining influence of détente and launch out on some military adventure.”211 He claimed that a difficult conversation ensued on the topic of NATO’s self

${ }^{208}$ Ibid. Brzezinski mentioned that NATO Summits and Economic Summits were the only established fora in which the leaders regularly met. Also he was aware of the problems of the structure and appearance of informal meetings. Former French President de Gaulle had once suggested unsuccessfully the establishment of a NATO directoire that should have been comprised of the United States, the United Kingdom and France as NATO's lead—and nuclear-nations. Obviously, the perception of establishing such an institution needed to be avoided in 1978 considering the possible reaction of all other NATO partners. Compare with Stromseth, 97. According to Stromseth, France intended in the early 1960s the establishment of a three-power directorate to "make joint decisions in all political questions affecting global security, ... especially as regards the use of nuclear weapons."

${ }^{209}$ Brzezinski, 294-295. The Caribbean islands of Guadeloupe are a part of France and have the status of a French overseas department (départment d'outre-mer).

${ }^{210}$ Ibid., 294. Though the meeting had an informal character, the participants had the expectation that a common general position on how to proceed concerning LRTNF modernization and arms control could be identified as the precondition for future discussions. Also see Wiegrefe, 262. Due to the fact that no official notes were taken, all findings and descriptions of the meeting are based on personal notes by the heads of government or their aides, respectively. In addition to that, summaries were provided after the meeting in the capitals to inform the respective administrations. These could also be taken into consideration to the same degree as interviews that have been conducted later. Carter, Brzezinski and Schmidt referred in their memoirs to their personal notes and diary entries. Wiegrefe and Soell referred mainly to summary notes and interviews as well as contemporary newspaper articles.

${ }^{211}$ Carter, 234. 
defense. Carter stated that the alliance needed to counter the Soviet SS-20 threat, but that no European country was willing to accept neutron weapons, cruise missiles, or Pershing II missiles on their soil. The French president supported Carter’s view that Europe needed “to evolve a weapon capability to trade off for the SS 20’s.”212 Carter described Schmidt’s position to be “contentious” because the German Chancellor insisted that other countries accept weapon deployment before Germany would do the same. According to Carter, British Prime Minister Callaghan stated that it was necessary to include European LRTNFs in future SALT III negotiations. Carter concluded from these different positions that the conversation was “obviously inconclusive, but typical for the problem the United States had faced for a long time in shaping a response to threats against Europe.”213 His way ahead following these discussions was "to move forward with design and to develop some production capability; go all-out to implement very restrictive SALT agreements; seek unanimity within NATO.”214 Carter stated that it was agreed to send a U.S. representative to Europe after the European leaders had “consulted more thoroughly with their military leaders." 215

Brzezinski supported Carter's account in his memoirs. He stated that Carter was very effectively leading the conversation and pressed "the others to define their responses to the perceived threat." ${ }^{216}$ Brzezinski found Giscard to be “clear, to the point, and quite decisive. Callaghan displayed good political sense, was quite vigorous, and spoke very sensibly." ${ }^{217}$ About Schmidt, he wrote that he was "most concerned about the Soviet nuclear threat in Europe and the

\footnotetext{
${ }^{212}$ Ibid., 235.

${ }^{213}$ Ibid. He also expressed his frustration about the fact that the United States were expected to design, develop, and produce new weapons but European leaders were not willing to agree in advance on a deployment.

${ }^{214}$ Carter, 235-236.

${ }^{215}$ Ibid., 236.

${ }^{216}$ Brzezinski, 295.

${ }^{217}$ Ibid.
} 
least inclined to agree to any firm response.”218 Brzezinski concluded that a more concrete Western position was needed. ${ }^{219}$ Helmut Schmidt noted in his memoirs that "[f]or several observers it was spectacular that next to the head of government from the USA, Great Britain and France, the German head of government became evident as the fourth member of the North Atlantic Alliance’s leadership group.”220

Carter held out the prospect of deploying new LRTNWs in Europe. ${ }^{221}$ He requested a deployment agreement from his partners as a precondition to seek funding from the U.S.

Congress. The answers nevertheless disappointed the U.S. president. Schmidt agreed in principle if other countries would agree for a deployment on their soil, too. Callaghan and Giscard did not provide full support, either. The French president left no doubt that France would not participate in a modernization program. The United Kingdom wanted to wait for results about LRTNWs from the next U.S.-Soviet summit meeting. ${ }^{222}$

At the end of the first day of the Guadeloupe meeting President Carter faced the same problems he encountered previously with the ERWs. The next morning, Carter pronounced that he would engage Brezhnev on the SS-20 topic and offer him negotiations, based on the modernization program. He asked the Europeans to provide him with proposals for details he

${ }^{218}$ Ibid.

${ }^{219}$ These conclusions about the Guadeloupe meeting by the two U.S. participants are somewhat in contrast with the assessments expressed in German literature. Wiegrefe stressed that the participation of the German Chancellor in Guadeloupe provided him and the German Federal government with an "enormous amount of increase in standing." Wiegrefe referred mainly to the fact that for the first time after World War II, a German Chancellor was recognized on "eye-level” by the leaders of Western victorious powers. Wiegrefe, 262.

${ }^{220}$ Schmidt, 233.

${ }^{221}$ Wiegrefe also described that President Carter offered to include LRTNF in future SALT III negotiations and that the other three principals agreed on this. He mentioned that Schmidt and Callaghan agreed immediately. Giscard agreed after he was convinced that French nuclear weapons would not be subject to SALT III negotiations. Wiegrefe, 262.

${ }^{222}$ Wiegrefe, 263. He claimed that a meeting between Carter and Brezhnev on the occasion of the signing of the SALT II treaty was commonly expected in due time. 
should mention to Brezhnev. U.S. Deputy National Security Adviser David Aaron would be sent to Europe for further consultations. Schmidt welcomed the approach but refused to take the lead in providing proposals. He suggested that David Aaron should come to the European capitals with clear proposals. ${ }^{223}$

Helmut Schmidt remembered the meeting differently then Carter and Brzezinski. Schmidt mentioned President Carter's statement that the grey zone weapons issue was of particular concern for Germany. To counter these concerns and reestablish the balance, Carter suggested countering the Soviet SS-20 systems with medium range missiles. Schmidt stated that he was not prepared for Carter's proposal. ${ }^{224}$ Thus, he responded that he expected the two European nuclear powers to answer, first. He recalled that the British Prime Minister took the lead. Callaghan stated that “such a step” would likely be necessary but only after U.S.-Soviet negotiations about the grey zone weapons failed. ${ }^{225}$ Callaghan pleaded for an opening to such negotiations, soon. The French president agreed with Callaghan’s proposal but also stated that the Soviets already had an advantage and negotiations should be limited in time. Should there be no negotiation success after a defined period of time then American missiles should be deployed. Giscard considered it to be decisive to demonstrate determination towards the Soviets from the beginning. ${ }^{226}$

Schmidt eventually agreed with Giscard's statement. Still, the Chancellor stressed that the Federal Republic of Germany could not be the only country offering her territory for the new weapons. Other European NATO members had to put their territory at NATO’s disposal to

${ }^{223}$ Ibid., 264.

${ }^{224}$ Ibid., 233. This statement is in so far surprising as the HLG results of November 1978 already indicated that LRTNF modernization was a key issue. Also see Wiegrefe, 258.

${ }^{225}$ Schmidt, 233.

${ }^{226}$ Ibid., 233-234. 
deploy the new systems, should this be necessary. ${ }^{227}$ Schmidt continued that Carter accepted the solution of the three European main allies. Schmidt claimed that "this was the hour of birth of the later so-called dual-track decision.” ${ }^{228}$ Schmidt made clear that he wanted to avoid a special role for Germany. He further argued that the economic standing and the growing political weight of the Federal Republic of Germany already caused problems. This could be further exacerbated by stressing the extension of Germany's military weight—he mentioned the concentration of military forces and nuclear weapons on West Germany’s territory. ${ }^{229}$ Schmidt used these statements, explaining that Germany’s current strength made her more vulnerable than before, to warn the Allies to take her "seriously, but not to ask too much." 230

Hartmut Soell concluded that that United States profited from favorable European statements about the importance of SALT II at the end of the meeting. ${ }^{231}$ Additionally, the

${ }^{227}$ Ibid., 234. He also stated that he was aware that French doctrine would prevent France from offering her soil. Schmidt described the rationale for his statement in more depth. He stated that he had to take domestic issues - to include his own political party—under consideration. Personally, he was long convinced about the necessity of a balance of force in the grey zone and that successful negotiations required a "bargaining-counter" against the Soviets. Being the fact that this was only a "declaration of intent" to deploy assets, he was aware that Soviet propaganda would be fully mobilized against Germany. This led him to the conclusion that other states needed to share the burden of deployment, so Germany would not be the only focus area of Soviet attempts to discredit the TNF modernization decision.

${ }^{228}$ Ibid. Soell reflected in his biography about Helmut Schmidt in more detail on the reasons for the Chancellor's hesitation to support Carter's proposals more actively. He stated that prior to the Guadeloupe meeting Schmidt was willing to support LRTNFs modernization if this would be required from a military strategic point of view. This statement of Soell is in contradiction with Schmidt's accord that he was not prepared for Carter's proposal. According to Soell, Germany should neither be pushed in a singular position within the Alliance nor be isolated against Soviet pressure. Also, Schmidt expected increased domestic political pressure after a modernization program was agreed upon. Soell stated that this explained the mixture of rejection and caution Schmidt demonstrated in Guadeloupe. Soell, Helmut Schmidt: 1969 bis heute, Macht und Verantwortung, 729. Also see Schmidt, 233.

${ }^{229}$ Schmidt continued with—what Brzezinski would call in his memoirs "a rather elementary lecture”-an overview about Germany’s historical heritage and an explanation about Germany's vulnerability because of her divided status and the Berlin question. Soell, 729-730. Compare with Brzezinski, 295.

${ }^{230}$ Soell, Helmut Schmidt: 1969 bis heute, Macht und Verantwortung, 730.

${ }^{231}$ Ibid.,731. SALT II support from European leaders was Carter's most important concern to get Congressional support for the ratification of the treaty. For a more detailed description of the ratification problem, see Carter, 261-264. 
Pentagon and the NSC saw the advantage of deploying nuclear LRTNWs in Europe. Specifically, "the Germans could be shut up,” given their constant complaints about SS-20s, without making concessions towards the Soviets on more SNW systems at the SALT II negotiations. ${ }^{232}$ Intermediate range systems should be discussed in subsequent SALT III talks. ${ }^{233}$ The French president claimed later that he personally developed the approach that was later known as the dual-track decision in Guadeloupe. ${ }^{234}$ The British Prime Minster advocated a position that was closest to Schmidt's. ${ }^{235}$ He had to take domestic issues under consideration. Elections were upcoming in the United Kingdom. The British economy at that time suffered from strikes, high unemployment rates, and a rather weak currency and Callaghan’s reelection was uncertain. ${ }^{236}$ Schmidt mainly intended to use the threat of deploying LRTNFs against the Soviets and to build up pressure for negotiations with Moscow. He did not achieve this aim in Guadeloupe with “sufficient clarity."237

${ }^{232}$ Soell, Helmut Schmidt: 1969 bis heute, Macht und Verantwortung ,732.
${ }^{233}$ Ibid.,732-733. Including LRTNFs in SALT III would become a cause for dispute between Carter and Schmidt, later. Schmidt accused Carter after the SALT II treaty was signed that the U.S. President had not sufficiently insisted on LRTNFs being subject of SALT III while negotiating with Brezhnev in Vienna. Soell also mentioned that the French primarily wanted to keep their nuclear independence from NATO. An interconnection of NATO's LRTNF modernization with own, already ongoing modernization plans needed to be avoided. In addition to that, the proposed deployment of new assets in other European countries would likely draw Soviet attention away from potential targets on French soil. Also see Nuti, 66. Nuti described that Brzezinski saw Guadeloupe as an opportunity for President Carter to provide strategic direction to his main allies. He stated that there was some anxiety amongst European leaders about an overall scheme of the U.S. administration

${ }^{234}$ Valéry Giscard D’Estaing, Le pouvoir et la vie, vol. II (Paris: Compagnie 12, 1991), 363-385, quoted in Nuti, 66.

${ }^{235}$ Compare with Daalder, 183. He stated that prior to Guadeloupe, the British political leadership came to the conclusion that the Soviet LRTNF should be discussed during SALT III negotiations. They also agreed that this approach would likely require a NATO LRTNF deployment decision, first.

${ }^{236}$ Soell, Helmut Schmidt: 1969 bis heute, Macht und Verantwortung, 733. These worries were not unfounded. On May 4, 1979, Callaghan was replaced by Margret Thatcher, after the British Labour Party was defeated in general elections.

${ }^{237}$ Ibid. 
As a result, Schmidt acknowledged that the United States was primarily interested in a deployment decision and an arms control approach conducted in combination with LRTNW modernization. In consequence, it was agreed at Guadeloupe that “[a] new NATO working group, the Special Group, was given the task of reconciling the TNF modernization with the US-Soviet arms control negotiations. In addition, the range of weapon systems that NATO could deploy was reduced to two weapon systems.” 238

Overall, Guadeloupe did not bring the expected results for any of the participants. The United States had to acknowledge that her European allies—especially Germany—could not be persuaded to deploy new TNF systems without reservations. Still, President Carter needed their support for a successful conclusion of the SALT II treaty including the ratification of the U.S. Congress. European opposition to SALT II results was likely should the SS-20 issue not be appropriately addressed. The U.S. had to make concessions towards a more comprehensive arms control approach and the Europeans would not take the political responsibility for concrete modernization proposals. These had to be provided by the United States in advance. Concerning the deployment part, Carter found himself in a similar situation as experienced eight months earlier with ERWs: Europeans were willing to deploy only if the United States set the conditions for it. The Europeans insisted on serious arms limitation efforts as the precondition for their support.

The German government became aware that a decision about modernization and deployment of new TNF was mandatory and could not be avoided before negotiations would take place. This meant for the German Chancellor that he would face intense domestic problems as well as extended pressure from the Soviet Union. Being perceived as the main initiator of the discussion as a result of his London speech, Schmidt found himself in an uncomfortable position.

\footnotetext{
${ }^{238}$ Nuti, 66-67.
} 
His main allies expected him to demonstrate determination—or even to take the European lead— while at the same time he considered Germany's growing strength to be a major problem. With reference to Germany's history_-including the defeat in World War II and the specific German détente approach of the Ostpolitik—and her particular situation as a divided country in the center of the Cold War's demarcation line, Schmidt insisted on avoiding a German special role (Sonderrolle).

France and Great Britain also faced challenges in Guadeloupe. It became clear that the United States expected full support which at least in the French case was difficult without changing Frances own main doctrine. A German lead role could not be expected, given Schmidt's statements. The United Kingdom's Prime Minister was not eager to take the lead, either. He already faced massive domestic economic problems and his political survival was already at stake. In the end, the four heads of government accepted a compromise for the way ahead that was ambiguous and left certain space for interpretations. This reminded observers about the discussion regarding Flexible Response in the 1960s. Then, only the possibility for different interpretations led finally to endorsing the strategic concept. The same would happen in the 1980s with NATO’s dual track decision. The political foundation for it was laid in Guadeloupe in January 1979 and the main positions — as stated in the personal memoirs under considerationwould not change at least during Carter's presidency in the United States and during Schmidt's time as Chancellor of the Federal Republic of Germany.

\section{$\underline{\text { Political discussion in Germany after Guadeloupe }}$}

In Germany, the discussion about TNF modernization and the required German position for the NATO meetings was intense. Deputy National Security Adviser Aaron visited London and Bonn in February 1979 to discuss U.S. proposals, as agreed in Guadeloupe. He presented more or less the already known HLG suggestions about TNF modernization. The Germans agreed under the conditions that the decision about development and production remained a U.S. responsibility, 
Germany was not the only European deployment country, and an official NATO decision was passed to enforce non-deployment states' contribution on the decision. Aaron proposed to timely separate deployment decisions from negotiation offers. The U.S. intended to offer negotiations about LRTNWs to the Soviets only after SALT II was ratified. A European deployment guarantee would be required, earlier. This proposal was immediately rejected by the German government as a result of the latest domestic political discussions in the Federal Republic. ${ }^{239}$

Helmut Schmidt reported to a group of leading SPD members after the Guadeloupe meeting. He "justified the double-track decision by arguing that the parity between East and West at the level of strategic nuclear weapons made a Western counterweight to the Soviet superiority in the realm of medium-range missiles imperative.” ${ }^{240}$ In domestic politics, the resistance of certain segments of the governing SPD against any nuclear modernization had to be taken under consideration as well as public opinion. These were lessons learnt from the rather emotional and overheated West German ERWs discussion. The most difficult task was hence harmonizing the development of a unified NATO statement and reaching a political consensus in Germany at the same time. As a result, the Federal Security Council and the cabinet established and endorsed guidelines for negotiations. ${ }^{241}$ These should be used for NATO discussions as well as domestic debates. The guidelines consisted of already known and expressed claims. ${ }^{242}$

\footnotetext{
${ }^{239}$ Wiegrefe, 265.

${ }^{240}$ Haftendorn, Coming of Age: German Foreign Policy since 1945, 254. Also see Haftendorn, Sicherheit und Stabilität, 126.

${ }^{241}$ Haftendorn, Sicherheit und Stabilität, 125-126. Haftendorn referred to meetings of the Federal Security Council on January 20, 1979 and of the Federal Cabinet on January 31, 1979. The guidelines were printed in an article "Sicherheitspolitische Klausur des Kabinetts im Verteidigungsministerium, "Generalanzeiger für Bonn und Umgebung (February 1, 1979). In addition to that she referred to an article “Abrüstung: Gefühl im Herz, ”Der Spiegel, Nr. 6, (1979).

${ }^{242}$ Haftendorn, Coming of Age: German Foreign Policy since 1945, 254. These claims were the exclusion of Germany being the only deploying state; the stressing of Germany’s non-nuclear statusincluding the rejection of a "two-key system for Pershing II missiles, and the statement that decisions on development, production and stationing of nuclear weapons were the exclusive purview of the U.S. President; a statement that deployment decisions must be supplemented by a simultaneous offer of
} 
In January 1979, the defense political spokesman of the oppositional CDU/CSU, Manfred Wörner, had delivered a speech in the United States. He demanded the deployment of LRTNWs in Europe without reservations. He reasoned that the West needed to regain the "escalation dominance” that was threatened by the SS-20s. He even expressed that Europe needed to develop its own assets in case of a United States' refusal to deliver cruise missiles. ${ }^{243}$ Schmidt responded to Wörner’s statements in the German Bundestag that Germany as a non-nuclear state must not give the impression "of wishing to enforce Western nuclear decisions.”244 This rather moderate reply of the German head of government towards a member of the parliamentarian opposition was to be expected. Generally, the CDU/CSU opposition supported the Guadeloupe resolution for modernizing LRTNWs.

Helga Haftendorn described the parliamentary debate in Germany between the coalition of SPD and FDP and the CDU/CSU to be "but a rearguard skirmish." ${ }^{245}$ A more confrontational attitude was expressed by the leader of the Social Democratic faction of the Bundestag, Herbert Wehner, in an article he wrote at the end of January 1979. Wehner advocated in his article arms limitations and reductions instead of LRTNW modernization and concluded that a different approach would not take realty into consideration. Additionally, he described the Soviet weapon

negotiations. In addition to that, the guidelines stressed the necessity for joint and unanimous NATO decisions about LRTNF stationing. The paper concluded with the observation that NATO had no choice but introducing new systems, should the Soviet Union continue the SS-20 deployment at an undiminished rate.

${ }^{243}$ Soell, Helmut Schmidt: 1969 bis heute, Macht und Verantwortung ,733. Manfred Wörner was considered to be a defense expert and later became German Minister of Defense and Secretary General of NATO. According to Soell, the view Wörner expressed in his speech supported those in the United States who interpreted the Guadeloupe agreement primarily as a deployment decision. 24, 1979.

${ }^{244} \mathrm{Ibid}$. Soell referred to a speech in the German Bundestag, Helmut Schmidt delivered on January

${ }^{245}$ Haftendorn, Coming of Age: German Foreign Policy since 1945, 256. The main criticism of the CDU/CSU was that "there had been no military equivalent to political détente between East and West" and that "the German government had been too reluctant in working with the United States and the other allies on restoring the military balance.” 
potential to be "defensive." ${ }^{246}$ Schmidt took the reins and declared at an SPD faction meeting on

February 6, 1979 that “Bonn’s alliance policy is fixed in the cabinet and the Federal Security

Council and nowhere else.” ${ }^{247}$ Hans-Dietrich Genscher mentioned in his memoirs that Egon Bahr warned emphatically against rearmament of NATO and opposeded the introduction of new medium range missiles. He concluded that the SPD feared that rearmament could lead to an end of the détente policy. He assessed that this was the first indication for the "future grounds for divorce” of the SPD-FDP coalition caused by Social Democratic internal differences. ${ }^{248}$

The actual decision of the Social Democrats to support the Guadeloupe proposals and the following implementations both in the Bundestag and NATO was made on May 19, 1979. At a meeting of leading SPD politicians, SPD chairman Willy Brandt and Herbert Wehner refrained from stating opposition against Schmidt's approach. ${ }^{249}$ The government committed itself to the dual-track decision on a meeting of the Federal Security Council on June 13, $1979 .{ }^{250}$ Still, the party internal discussion continued until after Schmidt's governmental coalition broke apart in

${ }^{246}$ Ibid.She referred to an article of Herbert Wehner, titled "Deutsche Politk auf dem Prüfstand," Neue Gesellschaft, Nr. 2 (1979). It was published in January 1979. Also compare with Soell, Helmut Schmidt: 1969 bis heute, Macht und Verantwortung ,733. He described that Wehner also attacked Foreign Minister Genscher by naming it "indecent" if not "fraud" should the Foreign Ministry continue to "put the Soviet side on the dock" in questions related to disarmament and arms control. Also see Wiegrefe, 266, and Soell, Helmut Schmidt: 1969 bis heute, Macht und Verantwortung, 733. According to Soell, Wehner adopted in his article critical arguments, claiming the Foreign Ministry's fault on the MBFR negotiations' standstill.

${ }^{247}$ Soell, Helmut Schmidt: 1969 bis heute, Macht und Verantwortung, 734. He quoted from a manuscript of Schmidt's speech that consisted of 27 pages. Also see Wiegrefe, 266. Wiegrefe mentioned additional SPD internal opposition from recognized disarmament experts like Horst Ehmke and Alfons Pawelczyk. They promoted negotiations without a deployment decision.

${ }^{248}$ Genscher, 415.

${ }^{249}$ Haftendorn Sicherheit und Stabilität, 129. She stated that Brand declared himself a "non-expert" and Wehner primarily "smoked his pipe" at the meeting. Schmidt had managed to commit both party leaders in advance to his position.

${ }^{250}$ Ibid. 
1982. ${ }^{251}$ In 1979, Schmidt was able to convince his own party to support his security policy and finally to accept the dual-track decision. Still, some segments of the SPD remained unconvinced about LRTNW modernization and deployment of new medium-range missiles in Germany. The other two members of the party's leading troika, compromised of Willy Brandt, Herbert Wehner, and Helmut Schmidt, decided — though reluctantly—to follow the head of government. Risking the governing coalition was to be avoided. The FDP, led by Hans-Dietrich Genscher, had supported LRTNW modernization from the beginning on. ${ }^{252}$ The opposition in the German Bundestag promoted an approach closer to the United States' intentions. They were in favor of stationing U.S. medium-range systems to counter the Soviet systems and did not stress the arms control track to the same degree as the Social Democrats.

In addition to the parliamentary discussions, public opinion in Germany got more and more polarized on the question whether additional nuclear weapons should be stationed in Germany. A German peace movement (Friedensbewegung) established itself supported by prominent scientist, artists, political leaders and scholars. Though these groups were not yet organized enough to play a role in the parliamentary debate in Germany, they advanced intellectual content that was traditionally part of the SPD's political doctrine. ${ }^{253}$ Many Young

\footnotetext{
${ }^{251}$ For a more thorough description of the SPD discussion about the dual-track decision from 19791982, see Haftendorn, Sicherheit und Stabilität, 129-133. The same types of discussions like in Germany developed in many other NATO states, too. Many leaders of smaller European countries faced growing opposition at home and had difficulties promoting LRTNF deployment. In Italy, the Netherlands, and Denmark the governments feared a shift from leftist voters. In Turkey, Soviet economic help was at stake. In the United Kingdom on the other hand the newly elected Prime Minister Margret Thatcher opposed the dual-track idea by stressing the requirement for TNF modernization, alone. Spohr Readman, 79-80.

${ }^{252}$ Genscher, 414. Genscher even claimed that the concept that would later be known as the dualtrack decision was primarily developed within the Free Democratic Party. He referred to a meeting of the FDP's defense political committee where a resolution was prepared. It involved the deployment decision for Pershing II and cruise missiles, a negation offer towards the Soviet Union, and the possibility for an incremental decrease of LRTNF or the complete removal of these weapons. The FDP's leading committee approved this resolution on August 13, 1979.

${ }^{253}$ For a more detailed description of the German peace movement and the resulting implications, see Soell, Helmut Schmidt: 1969 bis heute, Macht und Verantwortung, 837-848. Also see Lawrence S.
} 
Social Democrats, the party's youth wing, identified themselves with the positions members of the peace movement expressed. Older party veterans that climbed the ranks at the period of détente and German Ostpolitk felt the same. Overall, the splitting of the SPD on the question of rearmament already began to emerge. Schmidt used his political weight and authority as the head of government, prevented his party from drifting apart and was able to assert himself against his inner party rivals.

\section{$\underline{\text { HLG and Special Group (SG) after Guadeloupe }}$}

At NATO’s spring summit in The Hague on May 31, 1979, Foreign Minister Genscher gave a speech that reaffirmed "the significance of the simultaneous allied commitment to future LRTNF [sic]deployments' and arms control negotiations.”254 Genscher stressed that concerns about bilateral relations with the Soviet Union were minor compared to common alliance security interests. NATO agreed that a minimum of TNF modernization was required and a nondeployment decision was not an option even if the Soviet Union reduced her SS-20 systems. ${ }^{255}$ Germany pursued three aims. She wanted to achieve unanimity among the NATO allies for a dual-track decision, the widest possible participation in LRTNF deployments, and a completed arms control package. ${ }^{256}$

Wittner, Confronting the Bomb: A Short History of the World Nuclear Disarmament Movement (Stanford: Stanford University Press, 2009),135-136, and 163-165.

${ }^{254}$ Spohr Readman, 80.

${ }^{255}$ Ibid. This statement is in so far of importance as there were tendencies in some NATO countries before, to aim for a Soviet reduction offer and abandon modernization plans, completely. This zero-option contradicted the argument that NATO faced a gap in her own deterrence posture as long as any Soviet grey zone weapons were deployed. Also, the Soviets used the zero-option argument by stating that a balance of forces already exited and NATO's modernization plans would tip this balance. Compare with Schmidt, 95. He quoted Brezhnev from a personal discussion on May 5, 1978 about the balance of forces. Brezhnev stated that "yet, we are in Europe in an approximate state of security equilibrium." This Soviet opinion was never accepted $\mathrm{b}$ the German Chancellor.

${ }^{256}$ Spohr Readman, 80. 
The HLG continued and the newly established Special Group (SG) began their work. The SG that was later renamed Special Consultative Group (SCG) was established in April 1979 as a result of the Guadeloupe meeting. The NATO Council in permanent session formally approved the establishment of the SG on April 6, 1979. ${ }^{257}$ The SG's task was "to develop an agreed NATO approach to an INF arms control agreement” in parallel to the HLG. ${ }^{258}$ Since the new LRTNW systems would be developed by the United States and that envisioned negotiations would be conducted by U.S. and Soviet representatives, the SG was chaired by Leslie Gelb, from the U.S. State Department. ${ }^{259}$ The SG was closely linked to the work of the HLG. ${ }^{260}$ The U.S. initial position for the work in the SG was that the arms control approach was a supplement and not a substitute for TNF modernization. ${ }^{261}$ Later, European concerns led to a consensus that emphasized the arms control aspect more substantially. ${ }^{262}$

The HLG reached an agreement about a proposal to the NATO Foreign and Defense Ministers for their planned meeting on December 12, 1979. The group proposed new deployments of intermediate-range nuclear weapons in Europe. A mix of cruise missiles and ballistic missiles was suggested. They should be deployed in several NATO countries. Overall, 572 new single warhead systems should be fielded. These consisted of 108 Pershing II ballistic

\footnotetext{
${ }^{257}$ Haftendorn, Sicherheit und Stabilität, 118-119.

${ }^{258}$ Glitman, 34.

${ }^{259}$ Ibid.

${ }^{260}$ Haftendorn, Sicherheit und Stabilität, 119. Amongst other thinks the mandates of both groups
} were closely linked and HLG members were deputies in the SG at the same time.

${ }^{261}$ Nuti, 67. According to Nuti, this was in accordance with the U.S. approach that TNF modernization was required "to restore confidence in the viability of NATO's spectrum of deterrence." Nuti referred to a U.S. memo named “Issue Paper on TNF Arms Control Objectives and Principles” from April 5, 1979, accessed from the Digital National Security Archive (DNSA). Also see http://www.wilsoncenter.org/sites/default/files/Euromissiles_Reader_PartII_Section\%20B (accessed January 2, 2014).

${ }^{262}$ Nuti, 67. Also compare with Haftendorn, Sicherheit und Stabilität, 117 and the findings about Aaron's visit in Bonn and London in this monograph. 
missiles to replace Pershing I systems in Germany and 464 BGM 109G ground-launched cruise missiles (GLCMs). ${ }^{263}$ These 464 GLCMs should be distributed in Germany (96 missiles), the United Kingdom (160 missiles), Italy (112 missiles), Belgium (48 missiles), and the Netherlands (48 missiles). ${ }^{264}$ Also, to avoid an increase of the overall amount of nuclear weapons, it was agreed to remove 1,000 TNW warheads from European soil. ${ }^{265}$

At the same time, the Special Group developed negotiation principles. Negotiations on LRTNWs should be conducted between the United States and the Soviet Union based on an equal outcome for both sides. Specific numbers were not suggested. The "lowest possible numbers" were envisioned depending on the conduct of negotiations. ${ }^{266}$ The negotiations should be part of future SALT III which linked LRTNWs to SNWs. The European allies would participate in the discussions by regular consultations with the United States. According to the guidelines from the Guadeloupe meeting, the SG "also worked out a special clause which made clear that if the Soviets dismantled their SS-20s, NATO would be willing to reconsider its own project of modernization." ${ }^{267}$ Genscher confirmed in his memoirs that the "preparation of the NATO dualtrack decision was a first class negotiating achievement of our NATO representatives and ... the

\footnotetext{
${ }^{263}$ Glitman, 36-37.

${ }^{264}$ Haftendorn, Sicherheit und Stabilität, 120.

${ }^{265}$ Glitman, 36-37.

${ }^{266}$ Ibid., 37. Glitman mentioned that Germany interpreted this principle that a zero-zero outcome
} was possible. The double-zero approach, meaning that neither the Soviet Union nor NATO would eventually possess any LRTNF in Europe played an important role in Germany after the dual-track decision was formally made. Schmidt favored this option from the beginning on as expressed in his London speech. Later, he described that he learned in 1983 about the so-called walk in the woods between Nitze and Kvitsinski, and the denial of the Reagan administration to accept the proposed outcome. He described that "should it be still possible to reach a zero-solution for the INF-problem, we will feel very justified."

Schmidt, 336. The walk in the woods proposal suggested to mutually limiting LRTNF systems in Europe to 75 launchers, and 150 nuclear capable aircraft for either side. Compare with Glitman, 75-78.

${ }^{267}$ Nuti, 67. For a more detailed description of the SG guidelines compare with Haftendorn, Sicherheit und Stabilität, 119-120. 
Special Consultations Group.”268 On September 28, 1979, both groups conducted a common meeting to harmonize their respective reports. The NATO NPG approved the proposals leading to the dual-track decision on November 13-14, 1979. The NATO Council in permanent session approved the common report on November 28, $1979 .{ }^{269}$

\section{NATO political discussions prior to the dual-track decision}

While NATO bodies successfully prepared the documents required for the ministerial meeting in December, the political discussion within the capitals, between the allies, and also with the Soviet Union continued. Some allied governments still hesitated to fully support the upcoming dual-track decision. Denmark, Belgium, and the Netherlands had to be convinced not to block the decision. Norway's foreign policy tradition forbade a deployment of weapons on her soil but she was generally willing to support the proposals. Italy on the other hand had explained after Guadeloupe that she would be willing to deploy medium-range assets on her soil. ${ }^{270}$

The SALT II treaty was signed on June 18, 1979 in Vienna after three days of consultation between the United States and the Soviet Union. ${ }^{271}$ President Carter and Secretary General Brezhnev met several times with and without their delegations on that occasion. Eurostrategic missiles were not part of the SALT II agreement and only discussed at the margins of the official negotiations. As agreed in Guadeloupe, Carter proposed to implement medium-

\footnotetext{
${ }^{268}$ Genscher, 417 . He particularly stressed that all alliance members had a great degree of influence on the conduct of both tracks.

${ }^{269}$ Haftendorn, Sicherheit und Stabilität, 121.

${ }^{270}$ Ibid., 118 and 121. She assessed that Italy, as a regular member of the economic summits, recognized pending marginalization after she was not invited in Guadeloupe. By supporting the TNF modernization proposals and offering own soil for deployment, the Italian government wanted to ensure that Italy would not be ignored, again. Belgium and the Netherlands faced generally insecure majority ratios within their governing coalitions and needed to take domestic reservations into greater consideration. Denmark conducted a non-deployment policy towards nuclear weapons and also had domestic problems, promoting LRTNF modernizations.

${ }^{271}$ For a detailed description of the negotiations and the respective outcomes of specific discussions see Carter, 242-265.
} 
range TNF in future SALT III talks. But this proposal was not made during official sessions.

Carter described that "[o]n the ride down the small elevator to lunch, Brezhnev and I were alone with the interpreters. At his request I agreed to give him a written copy of my proposals concerning the next steps toward SALT III ... At the embassy, I printed out this note by hand and gave it to Brezhnev when we met again that afternoon.”272

On October 6, 1979, Brezhnev gave a speech in East Berlin. He described the emerging Western plans of deploying new LRTNWs as “disturbing the European balance of forces” and announced additional Soviet armaments, should NATO proceed. ${ }^{273}$ Additionally, he threatened the Federal Republic of Germany with “counterstrikes.” ${ }^{274}$ Also, he made a couple of concrete proposals including the offer to reduce Soviet medium-range systems should NATO refrain from rearmament. He declared the willingness of the Soviet Union to include medium-range systems in SALT III and announced the unilateral and unconditional withdrawal of 20,000 Soviet Soldiers and 1,000 tanks from East Germany. ${ }^{275}$ Brzezinski argued that Brezhnev’s speech “was clearly a propaganda move and did not indicate any willingness to withdraw the SS-20s.”276 He reiterated

${ }^{272}$ Carter, 252-253. In his memoirs, Carter included a copy of this paper that was comprised of twelve main bullets concerning SALT III. Bullet J) of the paper reads: "[sic] BEGIN TALKS TO LIMIT AND CONTROL NUCLEAR WEAPONS NOT COVERED UNDER SALT II [medium-range and other theater weapons]." Also see Schmidt, 102-103. According to Schmidt, the fact that this proposal was discussed only amongst the two heads of delegation in Vienna caused serious problems for him on a meeting with Soviet politicians Kosygin, Gromyko, and Tichonov on June 25, 1979 in Moscow. Schmidt stressed the importance of including medium-range TNFs in future SALT III talks and argued that if eurostrategic weapons were not included in SALT III, the Western alliance would be forced to massively rearm. The Soviet partners replied that they did not understand this statement, claiming that "[n]either President Carter nor any other American mentioned medium-range weapons in Vienna at all." Schmidt described that he was "filled with consternation" and that Secretary of State Vance confirmed the Soviet statement the day after in Tokyo. He continued that a few days later, Moscow acknowledged that the subject was touched by Carter and Brezhnev during a discussion in an elevator. According to the Russians, Carter accepted at this time Brezhnev's statement that there were not enough SS-20s, yet.

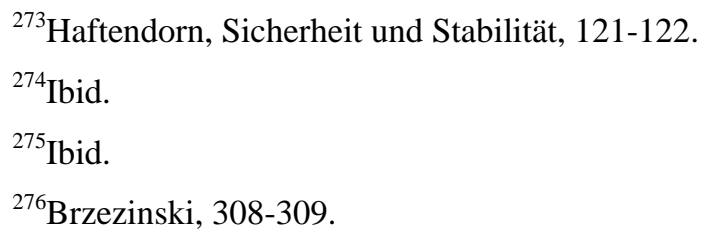


the importance of Germany's position on the upcoming dual-track decision and the influence on other European NATO states. He told President Carter that “[i]f Schmidt stays firm, others will also.” Yet, he wrote that "[w]hether Schmidt would hold firm was open to serious question.,"277

Helmut Schmidt stated about Brezhnev’s speech that he ignored the threats and welcomed the willingness for negotiations. Yet, he reminded Brezhnev about a Soviet-German declaration from May 1978: "Both sides assume that approximate levels and parity are considered sufficient for ensuring defense.”278 Afterwards he explained that even if the overall amount of launchers of Soviet SS-4s, SS-5s, and SS-20s would not be increased by replacing older systems, the advantages of SS-20 systems in mobility, firepower and range would shift the balance of forces to the advantage of the Soviet Union. ${ }^{279}$ After different meetings with Soviet politicians in October and November 1979, Schmidt concluded that the Soviet Union still did not understand in which position she put Western Europe and Germany in by increasing her SS-20 deployment. He stated that the Soviet Union overestimated the influence of the United States on her NATO allies, assuming an "absolute domination” of the Western alliance. ${ }^{280}$ Schmidt stressed that Carter’s failure to promote European interests at the SALT II negotiations heightened Soviet misperceptions even further. ${ }^{281}$

Genscher recalled that the Federal Chancellor, the Defense Minister, and he were aware of the fact that a historical decision was pending. He stressed that all three had been convinced

${ }^{277}$ Ibid., 308.

${ }^{278}$ Schmidt, 104. Also compare with Genscher, 415-416. Genscher used the Soviet-German declaration from May 1978 on a meeting with his Soviet counterpart Gromyko. The German side considered the declaration from the beginning on as the basis for future Soviet arms reduction to achieve the commonly envisioned balance of force. The Soviets later referred to an already existing balance of force that should not be disturbed by Western rearmament.

\footnotetext{
${ }^{279}$ Ibid., 104.

${ }^{280}$ Ibid., 107.

${ }^{281}$ Ibid., 107-108.
} 
that only NATO’s steadfastness would bring the Soviets to eventually agree to negotiations. Before the decision on December 12, 1979 took place, it was commonly understood within NATO that three to four years would pass before the first LRTNFs could be deployed. The Federal Republic of Germany wanted this period of time to be used for negotiations and to continue with détente and cooperation. ${ }^{282}$ Overall, Germany was at this point in time willing to support the pending dual-track decision in full. The political cooperation between the United States and Germany was very close. Both countries—-though for different reasons—could not afford to see the dual-track decision fail. ${ }^{283}$ Both countries also used their political influence to keep other NATO states on track to ensure that an unanimous decision would be made on December $12,1979 .^{284}$

\section{THE DUAL-TRACK DISCUSSION, ASSESSMENTS, AND CONSEQUENCES The formal dual-track decision}

A Special Meeting of NATO Foreign and Defense Ministers took place in Brussels on December 12, 1979 to formally endorse the dual-track or double-track decision. This meeting was scheduled before the regular ministerial meeting of December 13-14, 1979 and was exclusively dedicated to "theater nuclear force modernisation including the deployment in Europe of US ground-launched Cruise and Pershing II systems and a parallel and complementary arms control effort to obviate the need for such deployments.”285 France chose to abstain from the meeting

${ }^{282}$ Genscher, 417.

${ }^{283}$ Wiegrefe, 274-275.

${ }^{284}$ Ibid., 274. Specifically Denmark and the Netherlands still had objections against the dual-track decision. For a more comprehensive analysis about U.S. attempts to keep these allies as well as Norway and Belgium in line, see Daalder, 200-204.

${ }^{285}$ Compare with NATO, “NATO update 1979: Summary,” http://www.nato.int/docu/update/7079/1979e.htm (accessed January 5, 2014). The official NATO papers referred to a "double-track" decision 
given that she was not part of NATO’s integrated military structures. In the official communiqué that was issued to the public after the Special Meeting, NATO explained the decision in more detail. ${ }^{286}$ The decision was based on general quantitative and qualitative improvements of Soviet nuclear capabilities and specifically on her LRTNW modernization and expansion. Both the SS20 systems and Backfire bombers were explicitly mentioned. The communiqué also stressed Soviet improvements of her short-range TNF and her conventional forces against the background of strategic weapons parity. NATO concluded that Soviet TNF superiority would undermine the strategic balance and hence threaten the credibility of NATO’s deterrence strategy. Consequently, "Ministers concluded that the overall interest of the Alliance would best be served by pursuing two parallel and complementary approaches of TNF modernization and arms control.”287

The communiqué followed the recommendations of the HLG and announced the replacement of 108 Pershing I-A by Pershing II launchers as well as the deployment of 464 GLCMs. It stressed the participation of all nations that were members of NATO’s integrated defense structures. ${ }^{288}$ Also, the withdrawal of 1,000 TNW-warheads from Europe was announced to stress that NATO did not plan to increase her overall nuclear footprint. The following three paragraphs of the communiqué were dedicated to the parallel arms control approach. The SALT II treaty was explicitly welcomed and the communiqué stressed the approach to negotiate about

while many other contemporary writers use the term "dual-track" decision. The official communiqué of the Special Meeting does not mention either of the expressions. See NATO, "Ministerial Communiqué: Special Meeting of Foreign and Defense Ministers Brussels $12^{\text {th }}$ December, 1979," http://www.nato.int/docu/comm/49-95/c791212a.htm (accessed January 5, 2014).

${ }^{286}$ NATO, "Ministerial Communiqué: Special Meeting of Foreign and Defense Ministers Brussels $12^{\text {th }}$ December, 1979."

${ }^{287}$ Ibid., Bullet 6 .

288، Ministerial Communiqué: Special Meeting of Foreign and Defense Ministers Brussels $12^{\text {th }}$ December, 1979.” These weapons would be stationed in selected countries but "certain support costs will be met through NATO's existing common funding arrangements.” This step ensured at least to a degree the request of full nation's participation while stationing arrangements took military requirements into consideration. The limited range of Pershing II missiles required for example a deployment close to the demarcation line with the Warsaw Pact to enable the purpose of reaching Soviet terrain. 
LRTNW limitations during bi-lateral U.S.-Soviet SALT III talks. These talks should be based on the principle of equality. The final paragraph of the communiqué concluded that “[a] modernization decision, including a commitment to deployments, is necessary to meet NATO’s deterrence and defence needs, to provide a credible response to unilateral Soviet TNF deployments, and to provide the foundation for the pursuit of serious negotiations on TNF.” The second sub-paragraph stated that "[s]uccess of arms control in constraining the Soviet build-up can enhance Alliance security, modify the scale of NATO's TNF requirements, and promote stability and détente in Europe in consonance with NATO’s basic policy of deterrence, defence and detente as enunciated in the Harmel Report. NATO’s TNF requirements will be examined in the light of concrete results reached through negotiations.,289

The communiqué did not mention the NATO countries in which the LRTNWs should be deployed and the distribution of these systems. ${ }^{290}$ It clearly stressed the decision to deploy NATO LRTNWs independently from the outcome of possible future arms control negotiations. It is noteworthy that no specific deployment time-frame was mentioned though it was clear that a period of four years would be required to further develop the weapons systems under consideration. ${ }^{291}$ The arms control part of the communiqué deliberately did not mention any specific numbers that should be reached by arms control negotiations. This provided more flexibility for arms control talks. The particular formulations in the communiqué once again allowed for ambiguous interpretations within the Alliance about the envisioned level of reduction.

${ }^{289}$ Ibid., Paragraph 11 A and B.

${ }^{290}$ These arrangements remained part of classified documents that were agreed upon during the Special Session. NATO followed the HLG recommendations in preparation of the meeting. The overall numbers and distribution plans for the respective countries followed the recommendation of the HLG. All 108 Pershing II systems were to replace Pershing IA systems in Germany. Haftendorn, Sicherheit und Stabilität, 120.

${ }^{291}$ One of the main reasons to decide for the Pershing II systems was that the development of concurring Longbow missiles would have required possibly four more years and fielding could not be expected prior to 1987. Compare with Daalder, 192. 
The U.S. and many representatives of NATO's military structures were in favor of a minimum of U.S. LRTNWs independent from arms control approaches to strengthen the deterrence capability of NATO on all threat levels. They saw LRTNW deployments as the logical continuation and adaptation of Flexible Response to a changing reality.

For many European NATO members, the communiqué provided a base that would even allow for a future double zero solution should negotiations lead to such an outcome. It is certainly not accidental that the Harmel Report was mentioned in the last sub-paragraph of the paper. This reflected the European definition of Flexible Response by stressing the trinity of deterrence, defense and détente. Overall, the formulations of the communiqué and the resulting ambiguity can be considered as the result of intense common coordination to find formulations, every NATO government could accept.

\section{Assessment of the dual-track decision in the memoirs of former political leaders}

The dual-track decision has been repeatedly analyzed by politicians and scholars. Many of the above mentioned findings are reflected in these works and the corresponding conclusions. Jimmy Carter did not put a major emphasis on the dual-track decision in his memoirs. He stated that " $[\mathrm{b}]$ ecause of the rapidly developing imbalance in intermediate-range missiles in Europe, other NATO leaders and I decided in December 1979 to meet this threat with a limited number of Pershing 2 missiles and ground launched cruise missiles, to be deployed in Europe beginning in 1983.”292 He acknowledged that coming to an agreement on deployment of "the retaliatory weapons” was difficult. ${ }^{293}$ Carter stressed that some Europeans were willing to count on Soviet benevolence instead of their own strengths and will. They were willing to allow for Soviet

\footnotetext{
${ }^{292}$ Carter, 535.

${ }^{293}$ Ibid.
} 
nuclear dominance in Europe. This attitude would lead to a Soviet unwillingness to negotiate about LRTNW limitations and hence avoid restraining these weapons in Europe.

Brzezinski did not focus on "the so-called two-track policy decision,” either. ${ }^{294} \mathrm{He}$ described briefly the deployment track and the fact that 1,000 nuclear warheads would be withdrawn from Europe. He then stated that the "decision was coupled with a renewed emphasis on arms control.” ${ }^{295}$ Later, he stated that Schmidt was the initiator of the discussion about "[sic] Euro-strategic balance” and that the German Chancellor publicly stressed the threat of “decoupling” the U.S. from European security. ${ }^{296}$ Brzezinski argued that "[i]t was to meet that threat that the TNF initiative was developed after a number of discussions with Schmidt, in which he insisted that such a response was needed.”297

The dual-track decision was not considered to be a major achievement with far-reaching consequences for either U.S.officials. Both described the dual-track decision without much enthusiasm and rather briefly. They acknowledged that the decision was necessary. For Carter, the deployment decision was necessary to limit Soviet influence in Western Europe and as a precondition to persuade the Soviets for future arms reductions. Brzezinski described the decision merely as something that was required because the German Chancellor insisted on it. This supports the earlier finding in this monograph that SALT II was the focal point of U.S. arms control policy and that European support was required for the Congressional ratification process. The dual-track decision seemed to be a logical but not overly important step for the further achievement of bigger goals. The decision was not considered important enough to steer future security policy. This impression is even reinforced by studying Congressional Quarterly:

\footnotetext{
${ }^{294}$ Brzezinski, 309.

${ }^{295}$ Ibid., 309.

${ }^{296}$ Ibid., 462.

${ }^{297}$ Ibid.
} 
President Carter 1979 that according to the editor's foreword "provides a timely overview about Jimmy Carter's third year in office—a year that posed difficult challenges for his presidency."298 The dual-track decision was not mentioned at all in this volume comprised of 243 pages including annexes.

This leads to the question what else happened during that period of time under consideration. In 1979, the main subjects of U.S. foreign policy were in addition to the signing of the SALT II treaty in June, the improvements of the relations with China, the Israeli-Egypt peace treaty and the Iranian hostage crisis. In addition to that, the President and his administration had to focus on Cuba, where a perceived Soviet Brigade was advertised by the media after the SALT II treaty was signed. Also, first indications about the possibility of a Soviet intervention in Afghanistan occurred. This invasion eventually started on December 25, 1979. This list of major foreign and security related events helps to suggest why 1979 was considered to be a challenging year for Jimmy Carter. Also, 1980 was an election year and Carter and his team already worked on reelection and a second term in office. These factors explain to a great degree why the dualtrack decision did not gain greater attention in both U.S. memoirs under consideration.

Inside NATO, the dual-track decision was not perceived to be a successful demonstration of U.S. leadership and determination. This perception was shared by a range of domestic politicians in the United States. The reasons for this are that many concessions had to be made not only to Germany but also to all other European NATO partners. The Guadeloupe meeting and the findings about the HLG discussions showed that the U.S. starting positions in both areas had to be considerably altered before a consensus could be reached. From an American point of view, the dual-track decision was hardly a great political success.

\footnotetext{
${ }^{298}$ John L. Moore, ed., President Carter 1979 (Washington, DC: Congressional Quarterly, 1980),
} 1. 
Helmut Schmidt did not comment directly on the ministerial communiqué of the dualtrack decision in his book. He only described in detail the negotiation of the agreement. He focused on the reactions in the Soviet Union, the United States and Germany after the decision was announced. He remembered that the Soviet news agency TASS declared on December 14, 1979 that “NATO’s decisions had destroyed the basis for talks about medium-range weapons.”299 Still, he was convinced that the Soviets would eventually agree to arms control negotiations. Afterwards, the Soviet Union invaded Afghanistan and the U.S. president placed himself at the tip of a worldwide wave of outrage and condemnation. As a result, neither arms control talks, nor ratification of SALT II was possible in the near future.

Schmidt described that he continued working towards arms control negotiations. Neither U.S. sanctions because of the Afghanistan invasion, nor Soviet arguments condemning the dualtrack decision prevented him from giving priority to an arms reduction approach. ${ }^{300}$ Schmidt and Genscher visited Moscow on June 30, 1980. The German Chancellor stressed on the occasion that “any German government will stand by the principle of military balance” and that Germany made the effort of achieving this balance by “mutual arms restrictions on a lower level." ${ }^{301}$ This was followed by controversial and partly emotional speeches and discussions about the content of the dual-track decision. ${ }^{302}$ The Soviets finally announced that they would be willing to negotiate

\footnotetext{
${ }^{299}$ Schmidt, 108.
}

${ }^{300}$ After the Soviet invasion, the United States imposed amongst other things a trade embargo against the Soviet Union. Also, the SALT II ratification process stalled. The U.S. conducted a boycott of the Olympic Games in Moscow. Carter expected his Western Allies to support these measures. Most European states did not follow the trade sanctions and only some boycotted the Olympic Games. Schmidt, 108-109. For a more detailed description about U.S. sanctions compare with Carter, 471-483 and Brzezinski, 426-437.

${ }^{301}$ Schmidt, $110-111$.

${ }^{302}$ Schmidt described amongst other things a dinner speech he gave in presence of the Soviet Politbüro. He stated that he blamed the Soviet Union for the circumstances that made the double-track decision necessary. Afterwards he described how a member of the Politbüro dropped his translation of the speech loudly on the table. For a detailed description of the visit see Schmidt, 110-120. 
bilaterally and without preconditions with the United States about restrictions on medium-range nuclear weapons. ${ }^{303}$

Hans-Dietrich Genscher described that all participants were aware when NATO met on December 12, 1979 that it would require three to four years before the first U.S. LRTNWs would be deployed. He stated that "the Federal government wanted this period of time to be used for arms control negotiations with the Soviet Union.”304 Germany, as a divided country, was specifically interested in continuing the policy of détente and cooperation. He referred to his speech on the occasion of the Special Meeting of NATO Foreign and Defense Ministers. He had stressed then that delaying the decision about deployment was not an option. The Soviet Union would only negotiate if a concrete decision for stationing weapons was made. He concluded in his speech that "[t]his is why it is necessary that we decide today about the deployment.”305

Both descriptions of the former German Chancellor and the former Foreign Minister put an emphasis on the arms control track. Achieving arms reductions on medium-range TNF was the main goal of the German government concerning the dual-track decision. Genscher stressed the requirement for LRTNF deployments to a greater degree than Schmidt. In Genscher's speech to the German Bundestag on December 14, 1979 he stressed that "the modernization of mediumrange weapons is the appropriate answer on the spoiling of the balance of power caused by Soviet nuclear medium-range weapons pre-armament.” ${ }^{\text {306 }}$ For Genscher, the modernization was considered to be only a means to achieve the true goal of arms reduction. This approach was in contrast with the U.S. rationale. The importance of the dual-track decision for the German government was stressed amongst other things by the fact that Minister Genscher gave a speech

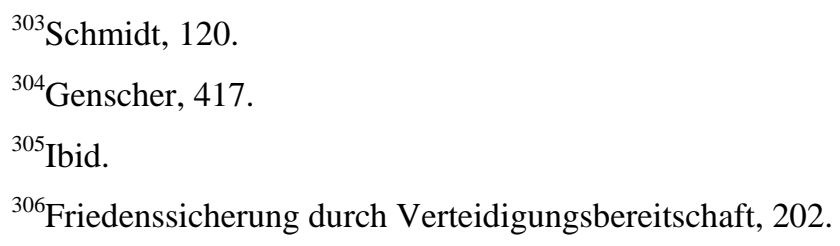


about the dual-track decision to the German Bundestag on December 14, 1979. The regular meeting of NATO Foreign Ministers in Brussels was not concluded at that time. In Germany, the dual-track decision was only the beginning of very controversial future discussions. It dominated the political debate until the mid-1980s and eventually was one of the reasons why the SPD-FDP coalition broke apart.

\section{Assessment of the dual-track decision by contemporary scholars}

Many scholars analyzed the dual-track decision and its development in detail.

Representing a German perspective, Helga Haftendorn spoke from a “double misunderstanding” that eventually led to NATO’s December 12, 1979 decision. ${ }^{307}$ She stated that the reasons for this double misunderstanding can be found in opposing and changing motives of the United States and the Federal Republic of Germany with which both sides supported the decision. According to her, the first misunderstanding concerned the origins of NATO’s rearmament. Schmidt aimed in his London speech on drawing attention to the question of military parity on all levels and wanted foremost SS-20 systems to be included in ongoing arms control negotiations. In the United States, this speech was interpreted to be a European request for similar U.S. systems. At first, the U.S administration was reluctant to consider this because SALT negotiations were given priority. This changed in late summer of $1978 .{ }^{308}$ From then on, the United States promoted a TNF

modernization program in Europe to cover the credibly of NATO’s defense as well as the military capability of deterrence. This complicated the situation. European concerns and political preconditions required extensive diplomatic skills and determination from the U.S.

\footnotetext{
${ }^{307}$ Helga Haftendorn, “Das doppelte Mißverständnis. Zur Vorgeschichte des NATODoppelbeschlußes von 1979,” Vierteljahreshefte für Zeitgeschichte, no. 2 (April 1985): 285, http://www.ifz-muenchen.de/heftarchiv/1985_2.pdf (accessed January 23, 2014).

${ }^{308}$ Haftendorn identified achievements in the LTDP process, the perception that SALT was on track, the first results of the HLG and in particular the ERW discussion as the reasons for a shift in the U.S. position. Compare with Haftendorn, “Das doppelte Mißverständnis,” 285.
} 
administration. As a result, the coupling of TNF modernization with a complex arms control approach was the United States' concession to her Allies. ${ }^{309}$

The second misunderstanding—as identified by Haftendorn—concerned the motives and reasons for the dual-track decision. For the United States, the modernization track followed a military based rationale. The Alliance required LRTNWs to counter Soviet SS-20 systems without the necessity of escalating to the SNW level—and hence extending a conflict to U.S. soil. The Europeans supported LRTNW modernization primarily because they wanted to emphasize the political coupling of Europe to the strategic arsenals of the United States. This was the only reason to agree on more vulnerable but politically more visible ground-based systems. ${ }^{310}$ In other words, the United States supported a rationale that the Europeans wanted to prevent on the first hand. Haftendorn concluded that these different rationales for LRTNW modernization eventually led to a greater decline of the credibility of the nuclear guarantee than the dual-track decision could reinforce. ${ }^{311}$

Another factor was the conflict of interests concerning arms control policy. The U.S. administration used arms control arguments primarily for domestic political reasons to increase the acceptance level of TNF modernization in Europe. For the Europeans, the arms control track was imperative and in line with earlier détente measures. Germany wanted to maintain the results of the Ostpolitk and at the same time keep the overall credibility of NATO. In Germany, the dualtrack decision was considered to be linked to military stability and détente in Europe. ${ }^{312}$

${ }^{309}$ Haftendorn, “Das doppelte Mißverständnis,” 285-286.

${ }^{310}$ Ibid., 286. Specifically Germany kept the option for sea launched cruise missiles open as long as she could. This would have prevented the discussion on a German Sonderrolle because then Germany would have not been the only country to host new LRTNF.

${ }^{311}$ Ibid.

${ }^{312}$ Ibid., 287. 
Maynard W. Glitman analyzed the dual-track decision slightly different. He referred to the communiqué and observed that "the broad action/implementation/conclusion portion of the dual-track decision was preceded by specific arguments and justifications for deployment ... while in the eyes of some NATO governments, arms control needed no such justification." ${ }^{313} \mathrm{He}$ also stressed that Denmark and Greece—due to their internal political situations—-did not block the decision but would use footnotes in later documents expressing concerns about several paragraphs. ${ }^{314}$ Glitman concluded that " $[\mathrm{t}]$ he majority of NATO member state governments were in agreement that the strategic and political situation necessitated the deployment of modernized U.S. INF missiles in NATO Europe. They had also offered to conduct arms control negotiations.”315

Ivo Daalder came to different conclusions. ${ }^{316}$ He identified domestic political considerations in NATO member states as one of the main drivers for the dual-track discussion. The challenge for NATO was, to "relate military and strategic factors to political considerations." ${ }^{317}$ Concerning military and strategic factors, he identified three general militarystrategic ways of thinking within NATO. These were used to justify the LRTNW modernization militarily within the framework of Flexible Response, stressing the deterrence pillar of the strategic concept. ${ }^{318}$ These also competed against each other. Daalder acknowledged that NATO

\footnotetext{
${ }^{313}$ Glitman, 42. Glitman analyzed the communiqué very thoroughly and provided his assessment on paragraphs and single lines. Compare with Glitman, 42-46.

${ }^{314}$ Ibid., 42. According to Glitman, Denmark later placed a "general reservation on parts" of the document and Greece "recalled its position" on "several parts."

${ }^{315}$ Ibid., 47.

${ }^{316}$ Daalder, 224-225.

${ }^{317}$ Ibid., 206.

${ }^{318}$ Daalder distinguished between proponents of a warfighting-deterrence strategy, an escalatorydeterrence strategy, and a conventional-deterrence strategy. These three strategic interpretations of NATO's deterrence pillar led to different requirements concerning LRTNF modernization. Specifically the number of warheads required to counter the Soviet systems differed substantially. Nevertheless, the scales were
} 
did not have an unambiguous strategic framework and different interpretations contributed to the problem of agreeing on how to proceed with the commonly accepted capability or deterrence gap, caused by Soviet LRTNWs. ${ }^{319}$ Concerning political factors, Daalder identified the imperative requirement for political support to formulate a commonly agreed compromise. ${ }^{320}$ Hence political factors drove the dual-track decision to a greater extent than military-strategic rationales. He finally concluded that "[t]he dual-track decision was therefore clearly responsive to the requirement to secure domestic political support for NATO decisions relating to nuclear weapons.”321

Haftendorn, Glitman and Daalder represented different approaches and interpretations. They indicated different ways of strategic assessments. Their respective conclusions were not completely in contradiction with each other. Haftendorn stated that the United States followed a military based rationale towards the LRTNW modernization requirement after 1978. Daalder's very thorough and comprehensive analysis about different types of military deterrence strategies demonstrated that he personally regarded the LRTNWs issue to be primarily a military-strategic problem. Daalder's main conclusion was though that political factors dominated over the military-strategic arguments to reach the dual-track decision.

Haftendorn was aware of the dominance of political factors for the dual-track decision. She stressed the intent of coupling Europe to the strategic arsenals of the United States, politically as the main rationale for European LRTNF modernization support. She considered the political

tipped primarily by political considerations, though the military-strategic rationales had some influence. For a detailed analysis of all three deterrence strategies, see Daalder, 207-224.

${ }^{319}$ Compare with Daalder, 206-207. Also compare with the findings in this monograph about Flexible Response.

${ }^{320}$ Ibid., 224. Daalder named the following facts as proof for his thesis: the coupling of modernization with arms control proposals; the replacement of older TNW warheads; the relatively small number of NATO LRTNF to be deployed; the choice of the Pershing II system instead of a system with greater range; and the Netherland's perspectives on cruise missiles.

${ }^{321}$ Ibid., 225. 
orientation of NATO and its strategic concept to be a given. The European emphasis on the arms control track was hence the logical consequence, stressing the détente approach as manifested in the Harmel Report from 1967. Glitman analyzed the dual-track decision merely as a deployment compromise. The arms control part was a concession to some European partners to make the dual-track decision politically supportable. His conclusions supported Haftendorn's theory of a double misunderstanding because Glitman—as a member of the U.S. administration—followed her argumentation concerning the U.S. rationale.

\section{Political development after the dual-track decision}

After the Soviet invasion in Afghanistan at end of December 1979, if not earlier, President Carter decided to take a hard line against the Soviet Union. The SALT II ratification process was stopped and talks about the second track—arms control negotiations about LRTNWs—-became impossible for an unforeseeable future. The Soviets had already announced on December 14, 1979 that negotiations would only be an option if NATO took back the LRTNW modernization decision. ${ }^{322}$ For its part, the U.S. administration focused on measures to punish the Soviets for their Afghanistan approach. ${ }^{323}$ In spring 1980, the U.S. administration and Chancellor Schmidt clashed on an issue that was closely related to the dual-track decision. Brzezinski related that Secretary of State Vance had issued a report after meeting with Helmut Schmidt on February 20, 1980. According to Brzezinski, the report indicated "without quite

\footnotetext{
${ }^{322}$ Schmidt, 108.

${ }^{323}$ For a detailed description of the U.S. approach after Afghanistan compare with Brzezinski, 426437. He described the so called Carter doctrine and linked Afghanistan to a greater Middle East approach including amongst other things the Iran crisis.
} 
saying so that Schmidt's earlier determination to stand fast with us was melting as quickly as snow in a late Rhineland winter.”324

Brzezinski recalled that President Carter noted on the report that Germany continued doing business with the Soviet Union and did not participate in sanctions against the Soviets or Iran, respectively. Brzezinski continued that Schmidt had made public statements in late spring 1980, suggesting a bi-lateral freeze in LRTNW deployments. Brzezinski assessed that Schmidt was "reacting to domestic pressures and perhaps anxious to preserve his self-appointed role as the West's interlocutor to Moscow.” ${ }^{325}$ Schmidt’s proposal would have contradicted the dual-track decision. After consultations with the German administration which stated that the press had misinterpreted the Chancellor, the U.S. administration proposed a message from President Carter to Chancellor Schmidt. The president sent a message that stressed the importance to "stand unambiguously on the NATO decisions” and that Schmidt's earlier statements—-though possibly misinterpreted by the press— “could be harmful to our collective efforts.” ${ }^{326}$ After Carter had approved the message, “someone in the State Department leaked it to both an American and European journalist.”327

Jimmy Carter also described these events that took place prior to a world economic conference in Venice, Italy. The meeting was scheduled for June 22, 1980. He remembered Chancellor Schmidt stating that he was in favor of a three year moratorium in which no new LRTNWs should be deployed in Europe. Carter quoted from the English translation of Schmidt's remarks as follows: "It would serve the cause of peace if during the next three years both sides

${ }^{324}$ Brzezinski, 462. This statement was not directly linked to the dual-track decision but to Germany’s support concerning measures against the Soviet Union after the Afghanistan invasion and Iran in connection with the hostage crisis.

\footnotetext{
${ }^{325}$ Brzezinski, 462.

${ }^{326}$ Ibid., 462-463.

${ }^{327}$ Ibid., 463.
} 
were to desist from any further deployments and begin negotiations on mutual limitations, soon.” ${ }^{328}$ Carter stressed that this statement was widely perceived as a German refusal to deploy new missiles in accordance with the dual-track decision.

He stated that Schmidt himself must have been concerned about this interpretation and had called the U.S. president immediately after the speeches. Schmidt told him that the press was “distorting his comments” and "he was not in favor of a freeze.” ${ }^{329}$ After Schmidt promised to contact the political leadership in Belgium, the Netherlands, Italy and other states to explain his position, Carter stated that he forgot about the issue for some time. Only after Schmidt continued to state his ambiguous message and the U.S. administration received calls from other European partners, Carter decided to approve the formal message to Schmidt that Brzezinski had referred to. Carter remembered that Schmidt complained about the content of the message after it was released by the press. Still, he could find no reason for the Chancellor to be embarrassed by the wording he chose. Carter stated further that "Helmut had become quite angry" and that "it was important for us to resolve any misunderstanding between us as soon as possible. ${ }^{330}$ Hence, a meeting between the U.S. and German delegation prior to the economic summit was arranged.

Helmut Schmidt described the events slightly differently. He stated that he indicated to President Carter in a call on April 16, 1980 an already publicly used thought about a possible memorandum. He wanted to provide an opportunity for the Soviets to agree to arms control negotiations within the framework of the dual-track decision. By doing so, the Soviets could keep

\footnotetext{
${ }^{328}$ Carter, 535. Technically, this statement was not directly contradicting the dual-track decision. NATO was aware that the first LRTNF could not be deployed prior to 1983 because the weapon development was not yet concluded.

${ }^{329}$ Ibid.

${ }^{330}$ Ibid., 536.
} 
their face in public. ${ }^{331}$ Schmidt hence suggested that both superpowers should announce unilateral declarations not to deploy any further LRTNWs until 1983. ${ }^{332}$ According to Schmidt, such a moratorium would have had no impact on NATO’s modernization track. The dual-track decision would profit from a moratorium because the arms control track could be started with lower numbers of Soviet systems available if the Soviets stopped their ongoing deployments. Schmidt confirmed Carter’s statement that the U.S. president wanted to take “wobbly” European governments in the Netherlands and Italy under consideration. ${ }^{333}$ Carter wanted to avoid the impression that the dual-track decision was challenged. According to Schmidt, Carter advocated informing all NATO partners about the proposal and to make at the same time clear that it was not in contradiction to the dual-track decision. ${ }^{334}$ Afterwards, Schmidt stated that there were various critical statements by members of the U.S. administration in May 1980 claiming a lack of loyalty of Europeans towards the United States.

Amongst other things Schmidt mentioned a "Washington inspired essay" in the journal Business Week that concluded Schmidt had retracted the dual-track decision by proposing the moratorium. In addition to that, the essay concluded that Germany was on her way to neutrality. ${ }^{335}$ Schmidt referred to the essay and stated that he never took "such nonsense" as serious, as opposed to President Carter. ${ }^{336}$ Schmidt claimed that the essay was inspired by the

\footnotetext{
${ }^{331}$ The Soviets had declared before that the dual-track decision prevented further attempts to negotiate about LRTNF. Schmidt's proposal aimed on unilateral declarations, so the Soviet Union would not appear to be weak or give way to Western pressure.

${ }^{332}$ Schmidt, 255.

${ }^{333}$ Ibid.

${ }^{334}$ Schmidt, 254-255.

${ }^{335}$ Ibid., 255. Also the French President came under attack and the Business Week essay called Schmidt’s upcoming Moscow visit “a God-given propaganda opportunity for the Soviets.”

${ }^{336}$ Ibid.
} 
President’s personal staff. ${ }^{337}$ On June 12, 1980 Schmidt received “an astonishing letter” from Carter that was immediately spread to the press. ${ }^{338}$ The letter referred to "contradictory press reports” and stated that the United States would not agree to any freeze, moratorium, or renunciation of LRTNW deployment. The United States would continue with rapid stationing of medium-range weapons. ${ }^{339}$ Schmidt concluded that the true reason for this letter was a preplanned meeting with Secretary General Brezhnev. He described the leaking of the letter to the press to be “rancor"-based. ${ }^{340}$ Then Schmidt stated that "someone wanted to vent his wrath who could never decide anyway whether the Germans or the Russians were the main enemy of the Polish people, of which he derived from, himself.» ${ }^{341}$

Schmidt described the unilateral focus of the U.S. position on the deployment of LRTNWs as the decisive point in the letter, he received from Carter. He complained about the lack of emphasis concerning the arms control track. Schmidt concluded that Brzezinski was satisfied with the Soviet rejection of arms control negotiations about LRTNFs and that Carter was mostly interested in demonstrating to the U.S. public toughness against the Soviet Union, without a real interest in Schmidt’s Moscow mission success. ${ }^{342}$

In Venice both delegations, including Carter, Brzezinski, Schmidt and Genscher, met on June 21, 1980. Schmidt used the occasion to explain in a rather emotional way how he felt being insulted by Carter's letter. The two heads of government discussed disputed questions, ranging from the Guadeloupe meeting, the ERW discussion, economy questions, the moratorium

${ }^{337}$ Ibid.

${ }^{338}$ Ibid., 256. This was the message Carter and Brzezinski were referring to in their memoirs.

${ }^{339}$ Ibid.

${ }^{340}$ Ibid.

${ }^{341}$ Ibid. Without naming him, Schmidt clearly referred to National Security Adviser Brzezinski who had Polish origins.

${ }^{342}$ Ibid. 
proposal, the SALT negotiations, financial questions, and sanctions against the Soviet Union. ${ }^{343}$ Schmidt spoke most of the time and gave vent to his anger on many issues. Schmidt claimed in his memoirs that he never intended to challenge Carter, but that he wanted to settle the controversy. The Chancellor wanted to have a free hand before visiting Moscow and for the remainder of 1980. Schmidt also stated that he was aware at that time that the White House needed his support for domestic reasons more urgently than he needed Carter's. He claimed that the Carter's "prestige at home and in the world was weakened" and his was not. ${ }^{344}$ Carter described the Venice meeting to be "an unbelievable meeting with Helmut Schmidt . . . ranting and raving about a letter that I had written him, which was a well-advised message.” ${ }^{345}$ He remembered Schmidt having said “Germany was not our 51st state” and that “[e]ventually, he relaxed enough to listen to what we were saying." ${ }^{346}$ Brzezinski stated that "it was an angry and at times an altogether unpleasant session, with Schmidt striking me as occasionally not being quite balanced." ${ }^{347}$

This was the last time Jimmy Carter and Helmut Schmidt discussed the dual-track decision as heads of government. Their descriptions about the moratorium and the Venice meeting can be seen as an example for the influence of personal relationships on important political questions like the dual-track decision. The content of the discussion demonstrated different national interests and interpretations about the conduct of the LRTNW modernization and arms control tracks. The way the discussion was conducted indicates that subjective factors played an equally important role. Schmidt focused in his book on the role and influence of

\footnotetext{
${ }^{343} \mathrm{~A}$ detailed accord of the statements and the respective topics can be found in Schmidt, 257-264.

${ }^{344}$ Ibid., 257.

${ }^{345}$ Carter, 536-537.

${ }^{346}$ Ibid., 537.

${ }^{347}$ Brzezinski, 463.
} 
National Security Adviser Brzezinski. According to Schmidt, Brzezinski used the topic of the moratorium to attack the German Chancellor's credibility. As a subliminal reason, Schmidt speculated about Brzezinski’s generally negative attitude towards Germany, based on his Polish origins. For Schmidt, Carter acted under the influence of his National Security Adviser and lacked the required understanding about international politics in his fourth year as President of the United States.

Carter on the other hand seemed to be concerned about the reaction of the German Chancellor. He dedicated four subsequent pages in his memoirs to describe the event. This does not seem to be a lot but the dual-track decision itself cannot be found in an equal setting. The way Schmidt approached him irritated him, and made him feel uncomfortable. Still, his calmness saved the day and the meeting did not end in a complete fiasco.

\section{The dual-track decision after Carter and Schmidt}

President Carter lost the 1980 election and Ronald Reagan was inaugurated as President of the United States in January 1981. Helmut Schmidt’s social-liberal coalition broke apart in 1982 and Helmut Kohl succeeded him as German Federal Chancellor. Hans-Dietrich Genscher remained Foreign Minister. The new German government immediately declared its support for the dual-track decision in full. ${ }^{348}$ In November 1983 the German Bundestag endorsed the implementation of the dual-track decision from 1979 in both parts. ${ }^{349}$ As a result, NATO started deploying the first Pershing II missiles in Germany in November 1983. On December 8, 1987, the

\footnotetext{
${ }^{348}$ Compare with "Erklärung der Bundesregierung zur Sicherheitspolitk nach dem Regierungswechsel: Tagung des Bundeskabinetts am 24.11.1982 (Auszüge)“ and Bundeskanzler Dr. Helmut Kohl, „Erste Regierungserklärung nach dem Regierungswechsel...(Auszüge) in Friedensicherung durch Verteidigungsbereitschaft, 292-295.

${ }^{349}$ Compare with "Durchführung des NATO Doppelbeschlusses vom 12. Dezember 1979 in seinen beiden Teilen. Antrag der Fraktionen CDU/CSU und FDP vom 18. November 1983,“ in Karl-Volker Neugebauer, ed., Grundzüge der Deutschen Militärgeschichte 2: Arbeits- und Quellenbuch (Freiburg: Rombach Verlag, 1993), 439-441.
} 
INF treaty was signed in Washington, DC. by President Reagan and President Gorbachev and this treaty eliminated any LRTNF between ranges of 500-5,500 km. ${ }^{350}$

\section{CONCLUSIONS}

\section{$\underline{\text { The compromise thesis }}$}

The first part of the author's thesis for this monograph dealt with the question whether the dual-track decision was a compromise. The sources used for this paper indicated clearly that there was not a common NATO approach towards the Soviet medium-range systems when Jimmy Carter began his presidency in January 1977. The incoming U.S. administration had no specific concept available on how to counter that threat. TNWs were not perceived to be of major importance in comparison with strategic weapons. The ERW affair of spring 1978 forced the United States to develop a new position towards TNWs because the Alliance and the public expected the President to demonstrate leadership and determination. European positions and objections against the ERWs were similar to arguments that were used later with respect to LRTNW modernization. A political attempt to bring NATO’s European leaders in line with a new U.S. approach failed at the Guadeloupe meeting in January 1979. Germany, France and the United Kingdom accepted only parts of the U.S. proposals. Their specific national interests led to a greater emphasis of arms control concerning the dual-track decision then the United States planned after 1978. Specifically Germany expressed preconditions that required additional coordination before a commonly acceptable approach could be identified.

Germany’s starting position in 1977 was foremost the hope that Soviet LRTNWs would be included in SALT II. President Ford raised Chancellor Schmidt's hopes that a solution for

\footnotetext{
${ }^{350}$ For a detailed description about the negotiations and the content of the „Treaty between the United States of America and the Union of the Soviet Socialist Republics on the Elimination of Their Intermediate-range and Shorter-Range Missiles" see Glitman, The last Battle of the Cold War.
} 
these eurostrategic weapons could be found in the near future. After Carter was elected it became soon clear that the new U.S. administration had different priorities as well as approaches.

President Carter's focus on human rights issues as well as his immediate deep-cut offer to the Soviets on nuclear weapons caused mistrust. Helmut Schmidt concluded that the new President of the United States lacked experience in foreign policy or an understanding about the Soviet's politics and their history. ${ }^{351}$ In addition to that, the U.S.-German relations were strained because of different views on a German nuclear power plant deal with Brazil and on U.S. requests to change the economic policy. ${ }^{352}$ When Schmidt gave his London speech in November 1977 he repeated requests that he had already made at the NATO summit in spring, which had failed to resonate in the United States. In London, he went public and initiated a political and public debate about grey-zone weapons and how to achieve parity on all levels.

The ERWs discussion emphasized the perception in Germany that the new U.S. administration was not capable of estimating the consequences of decisions on European allies. After Carter's decision to postpone the development and deployment, things got even worse. Schmidt had used his political weight to ensure German support for the ERWs deployment. He felt offended by Carter's decision and confirmed in his assessment that the United States had no clear line. The Guadeloupe meeting was a great win of international and domestic prestige for Schmidt-he was invited to confer with the former victorious Western powers on eye-to-eye. In Guadeloupe it became clear that Germany had a different main focus then the United States concerning LRTNW modernization. Schmidt stressed the specific German conditions and

\footnotetext{
${ }^{351}$ Schmidt explains that Carter's offer for reductions exceeding the Vladivostok accords had to be interpreted by the Soviets as a "trap" seeking U.S. advantage, only. Soviet political decision makers would never believe that the cause for such an offer could have honest reasons. In addition to that he explained that human rights following a Western understanding were historically not in existence in Russia or the Soviet Union. Hence, focusing on that issue had to fail concerning U.S.-Soviet negotiations. Compare with Schmidt, 224-231.

${ }^{352}$ For a comprehensive representation compare with Wiegrefe, 75-98.
} 
rejected a German Sonderrolle within the Alliance. He promoted the arms control track and saw LRTNW modernization as being unavoidable to achieve the final goal. This approach was in opposition to what the United States at that time promoted.

For the U.S. administration, LRTNW modernization was the logical consequence of a military-based situational assessment. ${ }^{353}$ One of the reasons for this mismatch can found in the different interpretations of NATO’s Flexible Response strategic concept as described in this monograph. For the United States, Flexible Response was primarily depicted in MC 14/3. Hence, a military approach towards LRTNW modernization was not an unexpected outcome though the State Department promoted a different approach. In addition to that, the emerging normalization of the relationship between the U.S. and China were of major importance for President Carter's foreign policy. Soviet SS-20 systems did not only threaten Western Europe but also the Chinese. Being threatened by the Soviets was a condition that caused the Chinese leadership to open up towards the United States. Germany, as a European NATO state, put emphasis on Flexible Response's political superstructure, the Harmel Report. Haftendorn described that retaining the two main pillars of Germany’s security policy_- “sufficient defense capability as well as a commitment to détente- and thus maintain the unity of its overall strategic approach” were the main reason to emphasize the negotiation aspect of the dual-track decision. ${ }^{354}$ This is in line with Helmut Schmidt's explanations that the results of the Ostpolitik should not be threatened by the dual-track decision.

The question stands whether these factors support Haftendorn's thesis of a double misunderstanding. Schmidt’s IISS speech emphasized the requirement for parity. Nevertheless,

\footnotetext{
${ }^{353}$ It should be noted that LRTNF modernization also had strong supporters in the integrated military structures of NATO as well as inside the German Bundeswehr's leadership. The Soviet SS-20 systems and the Backfire bombers caused a gap in NATO’s defense strategy that could be best closed by direct countermeasures.

${ }^{354}$ Haftendorn, Coming of Age: German Foreign Policy since 1945, 254.
} 
rearming was a mentioned option, though Schmidt preferred a solution based on arms control measures. Insofar is there no proof that the U.S. administration misunderstood the content of the speech. The second misunderstanding concerning the respective motives and reasons for supporting the dual-track decision can be challenged too. A prerequisite for a misunderstanding to occur is that at least one of the parties did not have the right information or misinterpreted facts. The German decoupling theory was well understood in the United States—some even promoted this approach. So was the U.S. tendency to develop strategies, based on military rationales, for the Germans. This was the old discussion that started after the Cuban missile crises and dominated the discussions about Flexible Response in the 1960s. At that time, the United States looked for ways to make small wars winnable without extending them globally.

Germany on the other hand always insisted that any war in Europe was not an option. The use of some TNWs or even modern conventional forces, only, would cause a catastrophe for Germany. Hence the threat of expanding any conflict towards a global nuclear war was considered to be the best assurance to avoid it. This is why Germany could not afford a decoupling from the United States. Also, the German détente approach was well known in Washington, DC and often criticized. Overall, the different motives and reasons within the United States and Germany were well understood and not so much a misunderstanding but rather different approaches to solve the same problem. Different national interests and different strategies led to the dual-track decision. The formulation was ambiguous enough for both sides to find their respective national interests represented. These findings support the thesis that the dualtrack decision was a compromise.

Different interpretations of the dual-track decision were not only possible, but the consequence of different Flexible Response understandings. The same is valid for the assessments of how and why to counter the Soviet LRTNW threats. Military-strategic arguments on the one hand and the political rationale of demonstrating alliance solidarity, keeping the 
deterrence function available, and continuing détente competed with other. At the same time, any decision had to be politically supportable within the distinct NATO countries. These facts support Daalder's approach and conclusions to a great degree. Specifically the internal German discussions within the Social Democratic Party are a prominent example of how important domestic political support became. Still, Daalder did not take personal motives, relationships and conviction of leading politicians into consideration. He analyzed national interests almost independent from these personal influences.

Overall, the findings of this monograph support the first part of the working thesis that the dual-track decision was a compromise, taking different national interests and strategies into account. The possibility to interpret the decisions differently and to focus primarily on the conduct of the most suitable interpretation for own, national interests is also supported. Specifically political and military arguments and interpretations competed with each other. This is in line with the findings about the earlier Flexible Response discussion. In 1967, both ways of justifying a strategic compromise were equally important. For the dual-track decision, politically motivated arguments nevertheless became more important and influential than military related rationales. Though military expertise significantly influenced the compromise formulation, the decisive factors for the compromise were of political nature. Subjective influence of former leading politicians on the dual-track decision cannot yet be determined. This requires a closer look on the findings based on Carter's, Schmidt's, Brzezinski’s, and Genscher’s personal memoirs.

\section{Individual influence on the dual-track decision}

The second part of this monograph's thesis looks into the question how much influence political leaders had on the dual-track decision. The findings of this paper indicate three major areas that have to be taken under consideration. The first area concerns the personal characteristics, motives, and convictions these leading politicians supported. These factors are 
specifically important while comparing Jimmy Carter and Helmut Schmidt as the respective individuals in charge. The second area deals with the formal and informal power leading politicians could bring to bear influencing the dual-track decision internationally and domestically. These factors limit the possibility for enforcing and influencing decisions because of organizational and structural parameters. The third area concerns their respective personal relationships and how much these might have influenced approaches towards another.

Descriptions about the personal characteristics, motives and convictions of Jimmy Carter and Helmut Schmidt can be found in their respective biographies. ${ }^{355}$ Findings of these works indicate that two smart and very determined personalities with their own—-though different— moral standards led the governments of the United States and Germany. Still, their backgrounds and areas of expertise differed substantially. Particularly on the field of international politics- to include security and defense, economics, and financial aspects—Schmidt had much more knowledge and experience than Carter could have had at the beginning of his presidency. Schmidt was very well connected within the United States as a result of international collaboration from his time as Minister and Chancellor prior to Carter's election and was aware of domestic issues within the United States. Carter, on the other hand, only had limited experience with Europe and specifically Germany. His memoirs and Peter Bourne’s biography indicate that domestic political contexts in Germany were rather unknown to him in 1977. Carter’s Christian based moral standards that influenced his thinking to a great degree were in contrast with Schmidt’s Realpolitik approaches based on Social Democratic base values.

Carter's winning personality and his rather calm disposition in discussions might have prevented an immediate clash of the two personalities. Schmidt interpreted these characteristics

\footnotetext{
${ }^{355}$ See Peter G. Bourne, Jimmy Carter: A Comprehensive Biography from Plains to Postpresidency. Also see Hartmut Soell, Helmut Schmidt: 1918-1969, Vernunft und Leidenschaft, and Hartmut Soell, Helmut Schmidt: 1969 bis heute, Macht und Verantwortung.
} 
as signs of weakness and indecisiveness. This often led him to the conclusion that he needed to state his arguments more aggressively to achieve results. Carter tended to listen to arguments, first, without making an immediate decision. Once he decided, nevertheless, he stood to his decisions and followed them with determination. Also, the fact that he listened to advice very carefully did not mean that he eventually adopted it as his own approach.

These factors lead to the conclusion that disputes between the two individuals could have been predicted based on their respective characters and backgrounds. This alone, however, would oversimplify matters. Schmidt for example, personally got along very well with other heads of government with an equally different personality. ${ }^{356}$ Both former heads of government have in common that they enjoy a great standing as elder statesmen. Overall, it can be concluded that the individual characters, motives and convictions played an important role in formulating policies as well as pursuing specific approaches like the dual-track decision. The personal relationship of both leaders was influenced to a great degree by their different personalities and backgrounds.

Concerning the formal powers and authority of the two heads of government, the situation is quite different. The President of the United States has a very strong constitutional position. This includes the authority of decision making concerning national strategies and policy. Still, the U.S. Congress influences these decisions. After Carter signed the SALT II treaty in 1979, he still required Senate ratification. One of the findings in this monograph is that the dualtrack decision is directly related to winning Congressional support. This required avoiding international opposition. International critique could have influenced members of the U.S. Congress and the public.

\footnotetext{
${ }^{356}$ For example Schmidt had a very good personal relationship with conservative French President Valérie Giscard d'Estaing as well as an appreciation and respect for British Prime Minister Margret Thatcher.
} 
During the Cold War, the United States of America was considered to be the leader of the Western Alliance. Though NATO was a consensus based organization—with important implications on the development of the dual-track decision—European allies have always been aware that U.S. leadership was a given. The SALT negotiations were conducted bilaterally with the Soviet Union and the same was expected for future SALT III talks. The Federal Republic of Germany in comparison was a non-nuclear, divided state in the center of Europe. She was economically and financially stronger than most other European allies. Militarily, she was the largest NATO contributor of conventional ground forces in Central Europe. Her Ostpolitk was a unique détente approach within the framework of the Harmel Report. Germany was frequently criticized for this approach within the United States. Concerns about self-neutralization or Finlandization can be found in the literature. ${ }^{357}$

The Federal Chancellor had a much weaker constitutional position than the U.S. President. German Ministers were generally independent and the Chancellor could only make use of his guideline competences to settle disputes. ${ }^{358}$ The government depended on the approval of the German Bundestag for the dual-track decision. Being the fact that party factions usually voted en bloc, this meant that the SPD and FDP majority of the Bundestag needed to support the decision. In the case of the dual-track decision, Schmidt’s biggest effort was to convince his own party to follow the governmental approach. He did not enjoy the same political freedom in Germany as President Carter had in the United States. The best indication for Schmidt’s personal influence on the dual-track decision inside the SPD can be found in the period of time after his government was replaced by a coalition of CDU/CSU and FDP. The SPD distanced herself

\footnotetext{
${ }^{357}$ Compare for example with Herf, 74.

${ }^{358}$ For a more detailed description of the position of the Chancellor of the Federal Republic of Germany see Deutscher Bundestag, Wissenschaftliche Dienste: „Richtlinienkompetenz des Bundeskanzlers,” http://www.bundestag.de/dokumente/analysen/2009/richtlinienkompetenz_des_bundeska nzlers.pdf (accessed January 11, 2014).
} 
already during the 1983 election campaign under leading candidate Hans-Jochen Vogel from the dual-track decision. Finally, at the SPD party convention in November 1983, the overwhelming majority of delegates voted against Schmidt's dual-track approach. From then on, the SPD officially opposed the modernization track and the Schmidt era was over.

Overall, the President of the United States and the Federal Chancellor were unequal partners concerning national ambitions, importance, and domestic power. Schmidt depended on U.S. support to a greater degree than vice versa. He could not afford bad relationships with the U.S. administration and he always took that under consideration. This nevertheless did not prevent him from seeking advantage when he identified an opportunity. Schmidt was well aware of domestic U.S. procedures and possibilities and used this knowledge to influence them. Both heads of government could not afford loosing NATO cohesion because of the common Soviet threat. This forced them to compromise, specifically with respect to the dual-track decision.

This leads to the third area of concern, the personal relationships of key decision makers and how much influence these had on the dual-track decision. Helmut Schmidt stated rather bluntly in his memoirs that he was not convinced of President Carter's capabilities to lead the Western Alliance. At the same time, he acknowledged the influence of National Security Adviser Brzezinski on the president and the United States’ foreign policy. ${ }^{359}$ Schmidt considered Brzezinski to be a "hawk,” who "probably considered himself [Brzezinski] a Realpolitiker.”360 At the same time, Schmidt described Carter to be a moralist. Schmidt concluded about the combination of both American politicians that they "overestimated the capability to design the world, purely by White House decisions.” ${ }^{361}$ This assessment of the U.S. leadership went beyond objective critique of policy or strategy. Schmidt clearly linked the characteristics and

\footnotetext{
${ }^{359}$ Schmidt, 230-231.

${ }^{360}$ Ibid., 231.

${ }^{361}$ Ibid.
} 
personalities of Carter and Brzezinski to decisions that Schmidt himself considered to be inappropriate. This assessment culminated in Schmidt's general conclusion that "Carter's idea of his moral position's superiority and his overestimation of the capability to design international politics, in combination with Brzezinski’s inclination, as a representative of a world power, to disregard interests of the German allies without much fuss,” were the drivers of the common relationships between the United States and Germany. ${ }^{362}$

Carter’s and Brzezinski’s recollections of the 1979 Venice meeting revealed that personal issues played an important role for the U.S. leadership, too. Carter seemed to be rather overwhelmed by Schmidt’s outburst. Such a reaction did not match Carter’s own approach towards solving problems. Brzezinski's reaction towards the German Chancellor was as aggressive, as Schmidt approached the U.S. delegation. Brzezinski had little sympathy for being treated by Helmut Schmidt in what he perceived was an inappropriate manner. Only Carter’s direct intervention with his National Security Adviser avoided a probable escalation of the dispute. $^{363}$

Overall, the personal relationships between Helmut Schmidt, on one hand, and Carter and Brzezinski, on the other, must be considered to be stressed at best. Mutual distrust in the respective other's approaches and rationales influenced the discussions and approaches towards another to a great degree. Nevertheless, this influence must not be overestimated. Heads of government promote first and foremost national interests. These are developed and formulated based on facts, assessments and taking national policies as well as personal agendas into consideration. Principals of states can usually not afford to let personal friendships or dislikes guide the formulation of their decisions to a great degree. Still, the implementation of decisions,

\footnotetext{
${ }^{362}$ Ibid.

${ }^{363}$ Compare with Carter, 537, and Brzezinski, 310.
} 
specifically when compromises are required because of diverging national interests, can be massively influenced by personal relations. Carter's and Schmidt's memoirs both provided evidence for this finding. For example, Schmidt referred to his relations with President Ford as being trust based. In consequence, Schmidt described how he trusted the United States to include discussions of SS-20 systems into SALT II without a written accord about the offer. Carter described his personal talks with Brezhnev, in the margins of the SALT II meeting in Vienna. At that time, he stated that he trusted the Soviet leader, only to be personally disappointed after the Soviet Union invaded Afghanistan in December 1979.

Personal relations between leaders cannot be ignored while assessing international decisions and outcomes. Concerning the dual-track decision, the findings of this monograph are that personal characteristics, motives and convictions of Jimmy Carter and Helmut Schmidt had a great influence on the respective national positions towards the decision. Formal and informal power of the leader's positions naturally determined the amount of influence the individuals could bring to bear. The personal relationships between Schmidt and Carter influenced the political climate and cannot be ignored with respect to the dual-track decision. Still, the personal relationships should not be overrated. National security interests dominated the dual-track decision. Better personal relationships would have likely not caused a completely different dualtrack outcome. 


\section{BIBLIOGRAPHY}

Bahr, Egon. “Wir haben Freiräume geschaffen,” Spiegel Special Geschichte 3 (2008): 88-92.

Biermann, Harald.“Stunde Höchster Gefahr.“ Spiegel Special Geschichte 3 (2008): 40-49.

Bourne, Peter G. Jimmy Carter: A Comprehensive Biography from Plains to Postpresidency. New York: Scribner, 1997.

Brzezinski, Zbigniew. Power and Principle: Memoirs of the National Security Adviser 19771981. New York: Farrar, Straus and Giroux, 1983.

Bundesarchiv der Bundesrepublik Deutschland. “1955: Die Hallstein-Doktrin.” Bundesarchiv, http://www.bundesarchiv.de/oeffentlichkeitsarbeit/bilder_dokumente/01366/index.html.d e (accessed January 21, 2014).

Carter, Jimmy. Keeping Faith: Memoirs of a President. New York: Bantam Books, 1982.

Clark, Donald L. “What’s an MBFR?” Air University Review (July-August 1976). http://www.airpower.maxwell.af.mil/airchronicles/aureview/1976/jul-aug/clark.html (accessed December 17, 2013).

Congressional Quarterly Inc. “President Carter 1978.” Congressional Quarterly (April 1979).

_. "President Carter, 1979.” Congressional Quarterly (1980).

Daalder, Ivo. The Nature and Practice of Flexible Response: NATO Strategy and Theater Nuclear Forces Since 1967. New York: Columbia University Press, 1991.

Deutscher Bundestag, Wissenschaftliche Dienste. Richtlinienkompetenz des Bundeskanzlers. http://www.bundestag.de/dokumente/analysen/2009/richtlinienkompetenz_des_ bundeskanzlers.pdf (accessed January 11, 2014).

Diefenbach, Karl. "Militärgeschichte nach dem Zweiten Weltkrieg: Vom Kalten Krieg zur Entspannung.“ In Grundzüge der deutschen Militärgeschichte: Band 1, Historischer Überblick, edited by Karl-Volker Neugebauer, 420-468. Freiburg: Rombach Verlag, 1993.

Facer, Roger L. L. Conventional Forces and the NATO Strategy of Flexible Response: Issues and Approaches. Santa Monica: RAND, 1985.

Gati, Charles, ed. Zbig: The Strategy and Statecraft of Zbigniew Brzezinski. Baltimore: The Johns Hopkins University Press, 2013.

Gavin, Francis J. Nuclear Statecraft: History and Strategy in America’s Atomic Age. Ithaca: Cornell University Press, 2012.

Genscher, Hans-Dietrich. Erinnerungen. Berlin: Wolf Jobst Siedler Verlag, 1995.

Glitman, Maynard W. The Last Battle of the Cold War: An Inside Account of Negotiating the Intermediate Range Nuclear Forces Treaty. New York: Palgrave Macmillan, 2006. 
Haftendorn, Helga. Coming of Age: German Foreign Policy since 1945. Lanham: Rowman \& Littlefield, 2006.

—. "Das doppelte Mißverständnis. Zur Vorgeschichte des NATO-Doppelbeschlußes von 1979.” Vierteljahreshefte für Zeitgeschichte, no. 2 (April 1985).

—. Security and Détente: Conflicting Priorities in German Foreign Policy. New York: Praeger, 1985.

—. Sicherheit und Stabilität: Außenbeziehungen des Bundesrepublik zwischen Ölkrise und NATO-Doppelbeschlu $\beta$. München: Deutscher Taschenbuch Verlag, 1986.

Herf, Jeffrey. War by other Means: Soviet Power, West German Resistance, and the Battle of the Euromissiles. New York: The Free Press, 1991.

Jacobsen, Hans-Adolf, Uwe Heuer and Hans-Jürgen Rautenberg, eds. Friedenssicherung durch Verteidigungsbereischaft: Deutsche Sicherheitspolitik 1949-1989; Dokumente. Mainz: v. Hase \& Koehler, 1989.

Lambach, Frank, ed. Our Men in Washington: From the first Prussian Minister Resident to the Ambassadors of the Federal Republic of Germany. Washington, DC: German Information Center, 2004.

Legge, J. Michael. Theater Nuclear Weapons and the NATO Strategy of Flexible Response. Santa Monica: The Rand Corporation, 1983.

Mahan, Erin R. and Edward C. Keefer, eds. Foreign Relations of the United States: 1969-1976, Vol. 32, Washington, DC: U.S. Government Printing Office, 2010. http://www.static. history.gov/frus/frus1969-76v32/pdf/frus1969-76v32.pdf (accessed December 17, 2013).

NATO. "Ministerial Communiqué: Special Meeting of Foreign and Defense Ministers Brussels $12^{\text {th }}$ December, 1979.” http://www.nato.int/docu/comm/49-95/c791212a.htm (accessed January 5, 2014).

_. "North Atlantic Military Committee Decision on M.C. 14/1: A Report by the Standing Group on Strategic Guidance, December 9, 1957.” http://www.nato.int/docu/stratdoc/ eng/a521209a.pdf (accessed January 20, 2014).

—. North Atlantic Military Committee. "Final Decision on MC 14/2 (Revised): A Report by the Military Committee on Overall Strategic Concept for the Defense of the North Atlantic Treaty Organization Area, May 23, 1957.” http://www.nato.int/docu/stratdoc/ eng/a570523a.pdf (accessed January 20, 2014).

- North Atlantic Military Committee. "Final Decision on MC 14/3: A Report by the Military Committee to the Defence Planning Committee on Overall Strategic Concept for the Defense of the North Atlantic Treaty Organization Area, January 16, 1968.” http://www.nato.int/docu/stratdoc/eng/a680116a.pdf (accessed January 20, 2014).

- "Report of the Council on the Future Tasks of the Alliance, December 1967." http://www.nato.int/cps/en/natolive/80830.htm (accessed December 4, 2013). 
—. "The Harmel Report.” http://www.nato.int/cps/en/natolive/topics_67927.htm (accessed December 4, 2013).

_. “The Nuclear Planning Group.” http://www.nato.int/cps/en/natolive/topics_50069.htm (accessed December 23, 2013).

—_. "NATO update 1979: Summary.” http://www.nato.int/docu/update/70-79/1979e.htm (accessed January 5, 2014).

Neugebauer, Karl-Volker, ed. Grundzüge der deutschen Militärgeschichte: Band 2 Arbeits und Quellenbuch. Freiburg: Rombach Verlag, 1993.

Nichols, Tom, Douglas Stuart, and Jeffrey D. McCausland, ed. Tactical Nuclear Weapons and NATO. Carlisle Barracks, PA: U.S. Army War College Strategic Studies Institute, 2012.

Niedhart, Gottfried. “Politik am heissen Draht” Spiegel Secial Geschichte 3 (2008): 78-87.

Noack, Hans-Joachim. Helmut Schmidt: Die Biographie. Reinbek bei Hamburg: Rowohlt Verlag GmbH, Berlin, 2010.

Nuti, Leopoldo. “The Origins of the 1979 Dual Track Decision - A Survey.” In The Crisis of Détente in Europe: From Helsinki to Gorbachev, 1975-1985, edited by Leopoldo Nuti, 54-71. London: Routledge, 2009.

Pifer, Steven. “NATO, Nuclear Weapons and Arms Control," Brookings Arms Control Series Paper 7 (July 2011). http://www.brookings.edu/ /media/research/files/papers/2011/7/19 \%20arms\%20control\%20pifer/0719_arms_control_pifer.pdf (accessed January 21, 2014).

Schild, Axel.“Das Böse Schlechthin.” Spiegel Secial Geschichte 3 (2008): 50-53.

Schmidt, Helmut. Menschen und Mächte. Jubiläumsausgabe. Berlin: Wolf Jobst Siedler Verlag, 1999.

Soell, Hartmut. Helmut Schmidt: 1969 bis heute; Macht und Verantwortung. München: Deutsche Verlags-Anstalt, 2008.

—. Helmut Schmidt: 1918-1969, Vernunft und Leidenschaft. München: Deutsche VerlagsAnstalt, 2003.

Spohr Readman, Kristina. “Conflict and Cooperation in Intra-Alliance Nuclear Politics: Western Europe, the United States, and the Genesis of NATO's Dual-Track Decision, 19771979.” Journal of Cold War Studies 13, no. 2 (Spring 2011): 39-89. http://www.mitpressjournals. org/doi/abs/10.1162/JCWS_a_00137 (accessed January 15, 2014).

Stromseth, Jane E. The Origins of Flexible Response: NATO's Debate over Strategy in the 1960s. New York: St. Martin’s Press, 1988. 
United States and Union of Soviet Socialist Republics. "Agreement Between The United States of America and The Union of Soviet Socialist Republics on the Prevention of Nuclear War." June 22, 1973. http://www.state.gov/t/isn/5186.htm (accessed February 15, 2014).

University of Minnesota Human Rights Library, "The Final Act of the Conference on Security and Cooperation in Europe, Aug 1, 1975, 14 I.L.M. 1292, Helsinki Declaration.” http://www1.umn.edu/humanrts/osce/basics/finact75.htm (accessed December 17, 2013).

U.S. National Security Council. Presidential Review Memorandum/NSC - 38, June 22, 1978. http://www.fas.org/irp/offdocs/prm/prm38.pdf (accessed December 26, 2013).

Wiegrefe, Klaus. Das Zerwürfnis: Helmut Schmidt, Jimmy Carter und die Krise der deutschamerikanischen Beziehungen. Berlin: Propyläen, 2005.

Wittner, Lawrence S. Confronting the Bomb: A Short History of the World Nuclear Disarmament Movement. Stanford: Stanford University Press, 2009. 